U.S. Department of the Interior

U.S. Geological Survey

Prepared in cooperation with the

Bureau of Land Management, Vale District Office, Vale, Oregon

\title{
Reconnaissance of Chemical and Biological Quality in the Owyhee River from the Oregon State Line to the Owyhee Reservoir, Oregon, 2001-02
}

Water-Resources Investigations Report 03-4327

Version 1.0

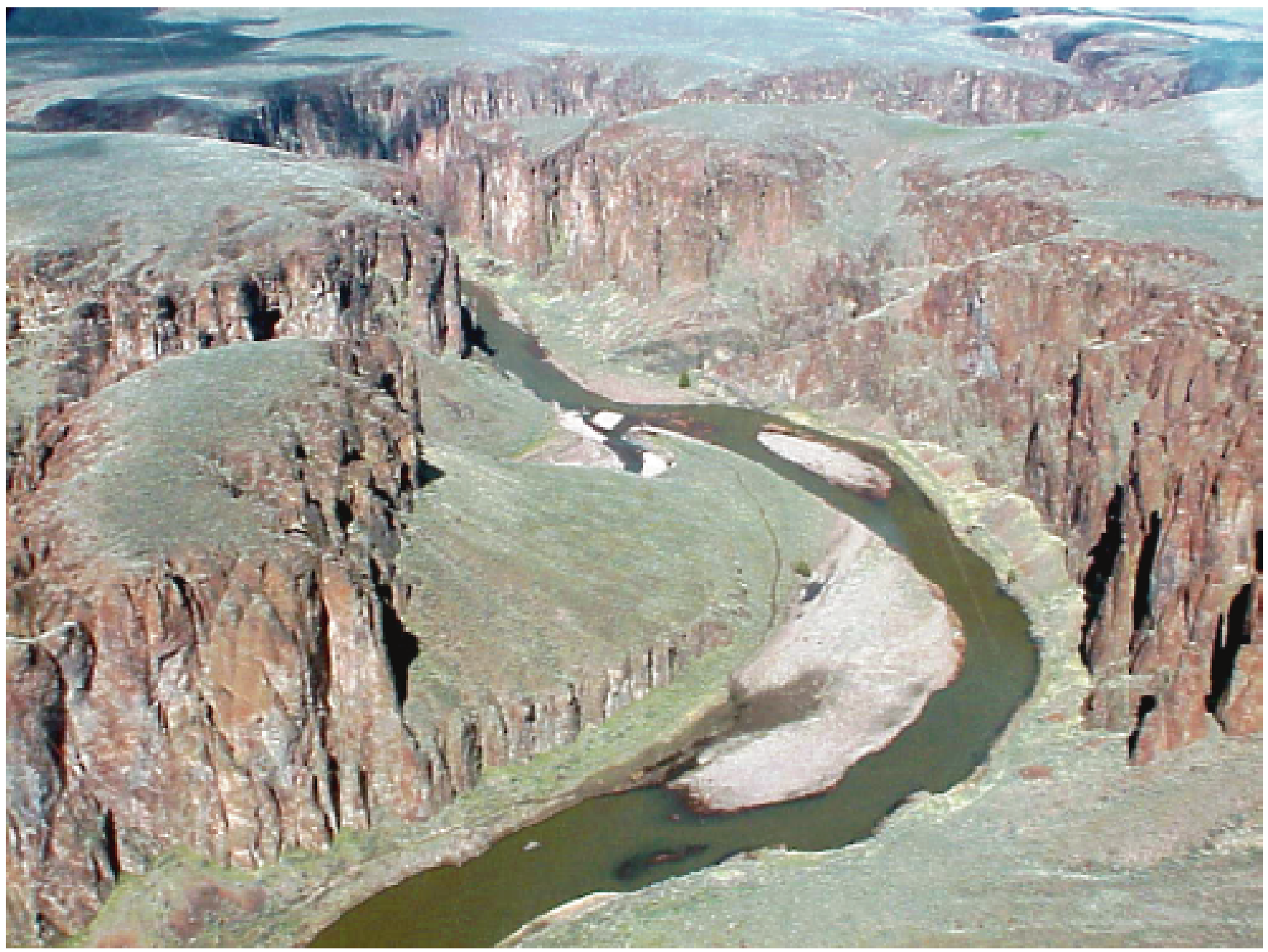


Cover: Owyhee River confluence with Little Owyhee River, Idaho, facing downstream. Photo by Dorene E. MacCoy, U.S. Geological Survey. 
Note changes to this report: Page 13, second paragraph under the heading NUTRIENTS, "dissolved" and table number " 3 " were changed effective December 7, 2004. 


\section{Reconnaissance of Chemical and Biological Quality in the Owyhee River from the Oregon State Line to the Owyhee Reservoir, Oregon, 2001-02}

By Mark A. Hardy, Terry R. Maret, and David L. George 


\title{
U.S. Department of the Interior \\ Gale A. Norton, Secretary
}

\section{U.S. Geological Survey Charles G. Groat, Director \\ Bureau of Land Management Kathleen Clarke, Director}

U.S. Geological Survey, Reston, Virginia; 2004

For more information about the USGS and its products:

Telephone: 1-888-ASK-USGS

World Wide Web: http://www.usgs.gov/

\begin{abstract}
Any use of trade, product, or firm names in this publication is for descriptive purposes only and does not imply endorsement by the U.S. Government.

Although this report is in the public domain permission must be secured from the individual copyright owners to reproduce any copyrighted materials contained within this report.
\end{abstract}

Hardy, M.A., Maret, T.R., and George, D.L., 2004, Reconnaissance of Chemical and Biological Quality in the Owyhee River from the Oregon State Line to the Owyhee Reservoir, Oregon, 2001-02: U.S. Geological Survey WaterResources Investigations Report $03-4327,48$. 


\section{Contents}

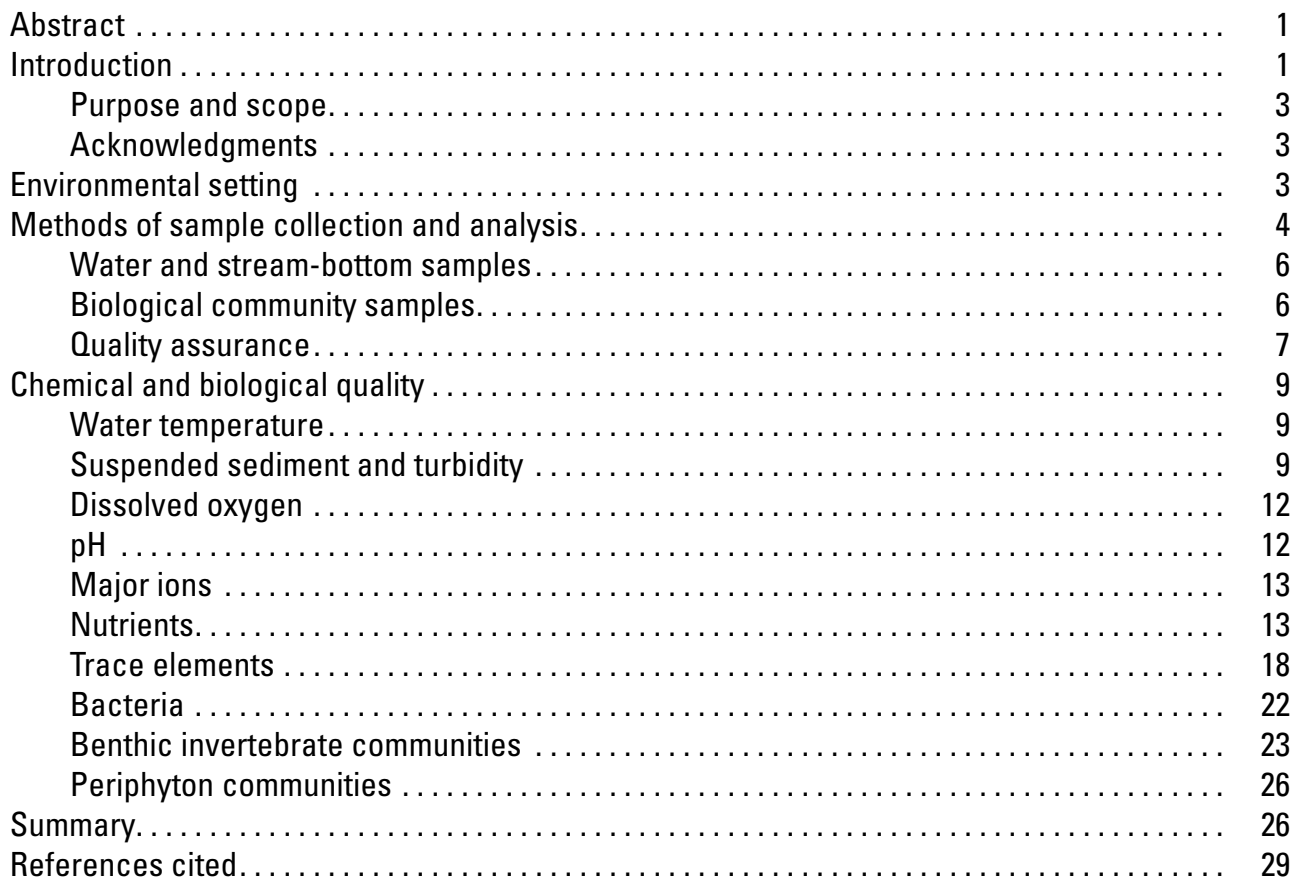

\section{Figures}

1. Map showing location of Owyhee River drainage basin, Nevada, Idaho, and

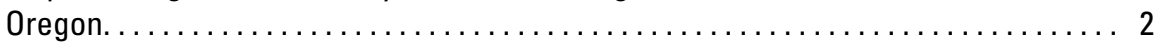

2. Map showing location of sampling sites in the Owyhee River study area, Oregon... 5

3-5. Graphs showing:

3. Flow-duration curve for 1949-2002 and sampling periods for the Owyhee River

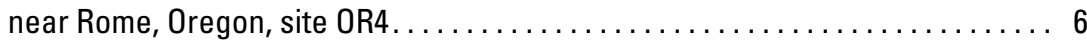

4. Water temperature in the Owyhee River and selected tributaries, Oregon, April

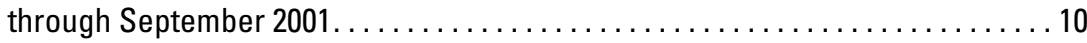

5. Suspended sediment concentrations, instantaneous loads, and turbidity in the Owyhee River and selected tributaries, Oregon, 2001 and 2002 . . . . . . . . 11

6. Diagram showing stiff patterns representing major ions in the Owyhee River and

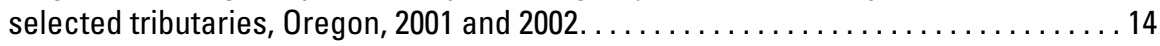


7-12. Graphs showing:

7. Nitrogen concentrations and instantaneous loads in the Owyhee River and selected tributaries, Oregon, during spring runoff in 2001 and $2002 \ldots \ldots \ldots 16$

8. Phosphorus concentrations and instantaneous loads in the Owyhee River and selected tributaries, Oregon, during spring runoff in 2001 and 2002 . . . . 17

9. Trace element concentrations in stream-bottom materials from the Owyhee River and selected tributaries, Oregon, in relation to concentrations in regional streams sampled by Rinella and others (1994).............. 19

10. Aluminum concentrations in stream-bottom materials less than 62.5 micrometers in diameter from the Owyhee River and selected tributaries, Oregon. . 20

11. Mercury concentrations in stream-bottom materials less than 62.5 micrometers in diameter from the Owyhee River and selected tributaries, Oregon. . 21

12. Number of macroinvertebrate and Ephemeroptera, Plecoptera, and Trichoptera (EPT) taxa collected at sites in the Owyhee River and selected

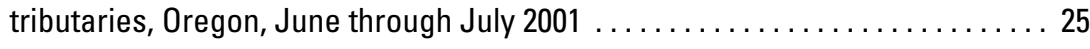

13. Diagram showing summary of water-quality issues for the Owyhee River and

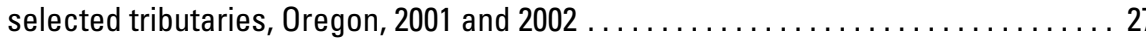

\section{Tables}

1. Description of sampling sites on the Owyhee River and selected tributaries,

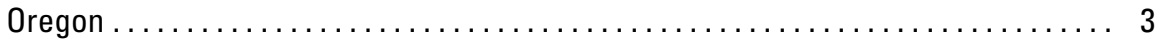

2. Land use/cover and mineable deposits in the Owyhee River study area, Oregon .... 4

3. Onsite measurements and chemical analyses of water and bottom-material samples collected from the Owyhee River and selected tributaries, Oregon,

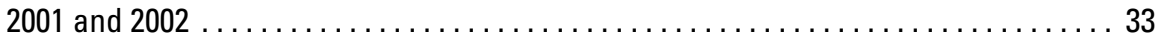

4. Chemical analyses of duplicate water samples collected from the Owyhee River and selected tributaries, Oregon, 2001 and $2002 \ldots \ldots \ldots \ldots \ldots \ldots \ldots \ldots \ldots$

5. Mass ratios of dissolved inorganic nitrogen to orthophosphorus as phosphorus for sites on the Owyhee River and selected tributaries, Oregon, 2001 and 2002 ...... 15

6. Concentrations and loads of total nitrogen and phosphorus at site OR1, 2001 and 2002, in relation to estimated average discharge to Lake Owyhee, Oregon, 1996-98 ............................................. 18

7. Stream-bottom materials less than 62.5 micrometers in diameter enriched in trace element concentrations, Owyhee River and selected tributaries, Oregon ........ 22

8. Benthic invertebrate metric results for the Owyhee River and selected tributaries,

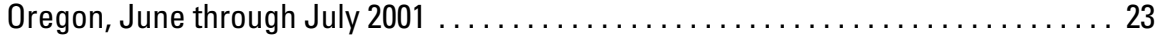

9. Benthic invertebrate abundance in the Owyhee River and selected tributaries,

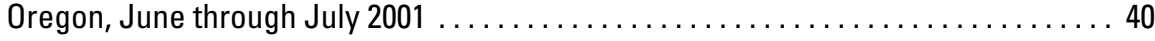

10. Microhabitat characteristics and periphyton results for the Owyhee River and selected tributaries, Oregon, June through July $2001 \ldots \ldots \ldots \ldots \ldots \ldots \ldots \ldots 24$ 


\section{Conversion Factors, Datum, and Other Abbreviated Units}

\begin{tabular}{lll}
\hline Multiply & By & To obtain \\
\hline cubic foot per second $\left(\mathrm{ft}^{3} / \mathrm{s}\right)$ & 0.02832 & cubic meter per second $\left(\mathrm{m}^{3} / \mathrm{s}\right)$ \\
foot $(\mathrm{ft})$ & 0.3048 & meter $(\mathrm{m})$ \\
inch (in.) & 25.4 & millimeter $(\mathrm{mm})$ \\
inch per year (in/yr) & 25.4 & millimeter per year $(\mathrm{mm} / \mathrm{yr})$ \\
mile (mi) & 1.609 & kilometer $(\mathrm{km})$ \\
pound per day $(\mathrm{lb} / \mathrm{d})$ & 0.4536 & kilogram per day $(\mathrm{kg} / \mathrm{d})$ \\
square mile $\left(\mathrm{mi}^{2}\right)$ & 2.590 & square kilometer $\left(\mathrm{km}^{2}\right)$ \\
ton per day (ton/d) & 907.2 & metric ton per day \\
\hline
\end{tabular}

Temperature is given in degrees Celsius $\left({ }^{\circ} \mathrm{C}\right)$, which can be converted to degrees Fahrenheit $\left({ }^{\circ} \mathrm{F}\right)$ by use of the following equation:

$$
{ }^{\circ} \mathrm{F}=(1.8)\left({ }^{\circ} \mathrm{C}\right)+32
$$

Sea level:In this report, "sea level" refers to the National Geodetic Vertical Datum of 1929 (NGVD of 1929) - a geodetic datum derived from a general adjustment of the firstorder level nets of the United States and Canada, formerly called Sea Level Datum of 1929.

\section{Other Abbreviated Units}

$\begin{aligned} \mathrm{g} & \text { gram } \\ \mathrm{L} & \text { liter } \\ \mu \mathrm{g} / \mathrm{g} & \text { microgram per gram } \\ \mu \mathrm{g} / \mathrm{L} & \text { microgram per liter } \\ \mu \mathrm{m} & \text { micrometer } \\ \mu \mathrm{S} / \mathrm{cm} & \text { microsiemens per centimeter } \\ \mathrm{mg} / \mathrm{L} & \text { milligram per liter } \\ \mathrm{mL} & \text { milliliter } \\ \mathrm{mm} & \text { millimeter (multiply by } 0.03937 \text { to obtain inch) } \\ \text { MPN/100 mL } & \text { most probable number per } 100 \text { milliliters } \\ \mathrm{m}^{2} & \text { square meter (multiply by } 3.281 \text { to obtain square foot) }\end{aligned}$


[This page intentionally left blank] 


\title{
Reconnaissance of Chemical and Biological Quality in the Owyhee River from the Oregon State Line to the Owyhee Reservoir, Oregon, 2001-02
}

\author{
By Mark A. Hardy, Terry R. Maret, and David L. George
}

\begin{abstract}
The Owyhee River drains an extremely rugged and sparsely populated landscape in northern Nevada, southwestern Idaho, and eastern Oregon. Most of the segment between the Oregon State line and Lake Owyhee is part of the National Wild and Scenic Rivers System, and few water-quality data exist for evaluating environmental impacts. As a result, the U.S. Geological Survey, in cooperation with the Bureau of Land Management, assessed this river segment to characterize chemical and biological quality of the river, identify where designated beneficial uses are met and where changes in stream quality occur, and provide data needed to address activities related to environmental impact assessments and Total Maximum Daily Loads. Water-quality issues identified at one or more sites were water temperature, suspended sediment, dissolved oxygen, $\mathrm{pH}$, nutrients, trace elements, fecal bacteria, benthic invertebrate communities, and periphyton communities.
\end{abstract}

Generally, summer water temperatures routinely exceeded Oregon's maximum 7-day average criteria of 17.8 degrees Celsius. The presence of few coldwater taxa in benthic invertebrate communities supports this observation. Suspended-sediment concentrations during summer base flow were less than 10 milligrams per liter (mg/L). Dissolved solids concentrations ranged from 46 to $222 \mathrm{mg} / \mathrm{L}$, were highest during base flow, and tended to increase in a downstream direction. Chemical compositions of water samples indicated that large proportions of upland-derived water extend to the lower reaches of the study area during spring runoff. Dissolved fluoride and arsenic concentrations were highest during base flow and may be a result of geothermal springs discharging to the river. No dissolved selenium was detected.

Upstream from the Rome area, spring runoff concentrations of suspended sediment ranged from 0 to $52 \mathrm{mg} / \mathrm{L}$, and all except at the Three Forks site were typically below $20 \mathrm{mg} / \mathrm{L}$. Stream-bottom materials from the North Fork Owyhee River, an area with no mines, were enriched with nine trace elements, which indicates that this basin may be a natural source of these elements.

Near Rome, the part of the study area not included in the National Wild and Scenic Rivers System, land-use impacts resulted in elevated populations of Escherichia coli bacteria (E. coli) during base flow and elevated concentrations of nitrogen and phosphorus during spring runoff. Sites in this area had the highest numbers of benthic invertebrates; the fewest Ephemeroptera, Plecoptera, and Trichoptera taxa; and the highest Hilsenhoff Biotic Index scores. These results suggest degraded stream quality. Periphyton communities at sites in this area approached nuisance levels and could cause significant dissolved oxygen depletions and $\mathrm{pH}$ values that exceed Oregon's recommended criteria. Stream-bottom materials from Jordan Creek were enriched with mercury and manganese, which probably were ultimately caused by past mining in that basin.

Below Crooked Creek, elevated suspended sediment concentrations $(142 \mathrm{mg} / \mathrm{L})$, phosphorus concentrations $(0.23 \mathrm{mg} / \mathrm{L})$, and E. coli populations (370 most probable number per 100 milliliters) during the largest spring runoff event could be the result of inputs at the lower end of Jordan Valley and (or) inputs from Crooked Creek. The New Zealand Mud Snail, a highly competitive gastropod introduced to the Snake River in the 1980s, was collected just downstream from the Crooked Creek confluence.

\section{Introduction}

The Owyhee River flows from northern Nevada, through southwestern Idaho, and into eastern Oregon (fig. 1), draining about $10,950 \mathrm{mi}^{2}$ of extremely rugged and remote landscape. From the Idaho-Oregon State line to Lake Owyhee, excluding $14 \mathrm{mi}$ in the Rome area, the river has been designated part of the National Wild and Scenic Rivers System. The Vale District of the Bureau of Land Management (BLM) is required to 


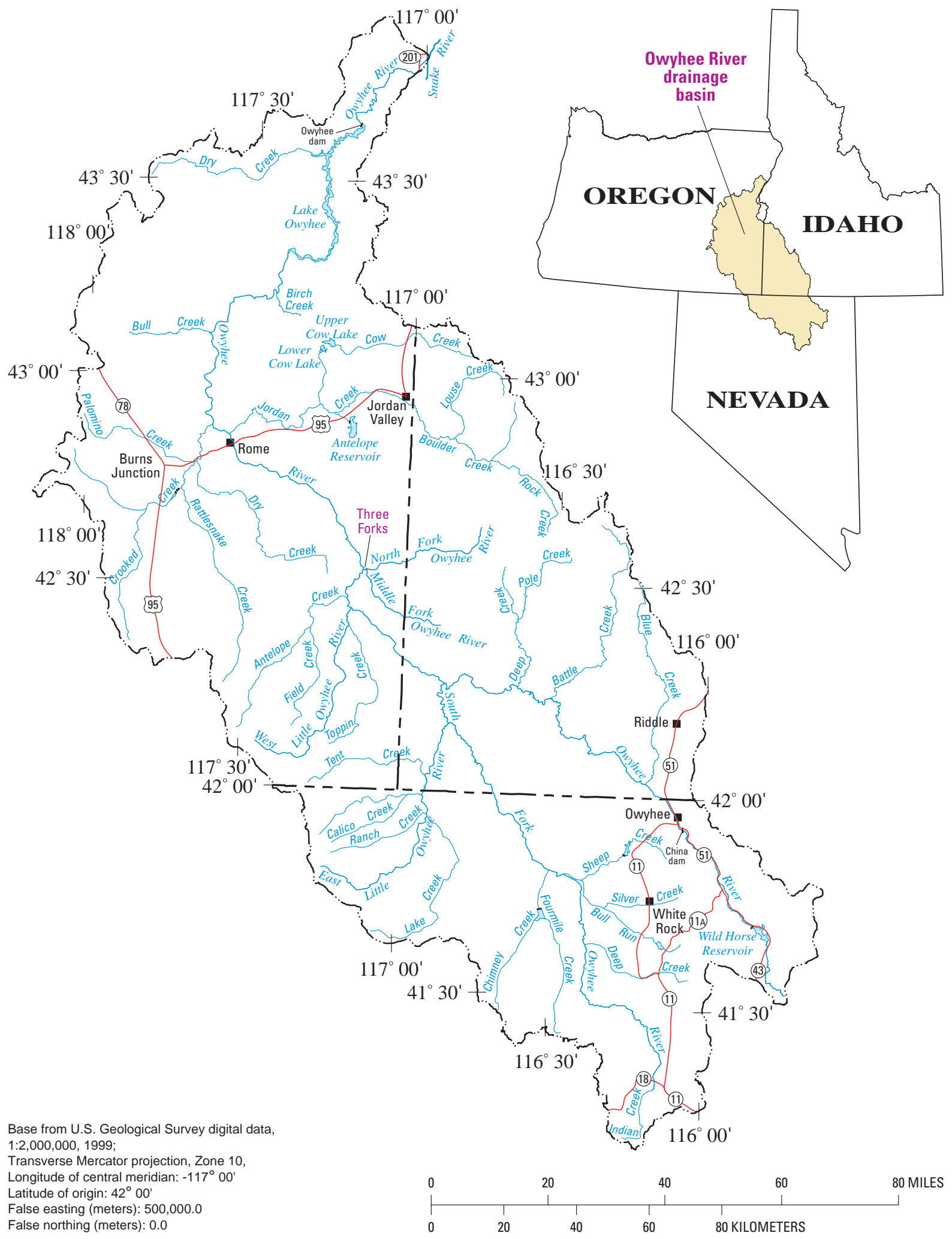

Figure 1. Location of Owyhee River drainage basin, Nevada, Idaho, and Oregon. 
ensure that its land-management actions do not impair the beneficial uses of this segment of the Owyhee River. Because access to the river is so limited, few data have been collected to determine beneficial uses that the river could support or to contribute to other activities related to the Total Maximum Daily Loads (TMDLs) process required by the Clean Water Act. The U.S. Geological Survey (USGS), in cooperation with the BLM, performed a reconnaissance study during 2001-02 that would provide data to help address these TMDL-related issues.

\section{Purpose and Scope}

This report describes a water-quality reconnaissance of the river segment between the Oregon State line and Lake Owyhee conducted to characterize chemical and biological quality, identify where major changes in water quality occur, and provide data that will help define beneficial uses and support TMDL-related activities. Stream discharge and samples of water were collected at 10 river and tributary sites (table 1) during two spring runoff events and during a summer base flow. Samples of stream-bottom materials, periphyton communities, and benthic invertebrate communities were collected at nine of these sites during summer base flow. Sample analyses included major ions, nutrients, and fecal-indicator bacteria in water; selected trace elements in stream-bottom materials; chlorophyll- $a$ content and biomass of periphyton communities; and species identification and enumeration of benthic invertebrate communities.

\section{Acknowledgments}

The authors gratefully recognize the efforts of the following USGS staff for collecting water, sediment, and biological samples; measuring streamflows; and arranging for delivery of time-dependent samples from field crews to processing laboratories: Joe Bunt, Bill Damschen, Ross Dickinson, Jack Doyle, Dorene MacCoy, Deb Parliman, Alvin Sablan, and Jim Schaefer. Special thanks also go to Jack Wenderoth, Brian Bidding, and Justin Robinson for arranging the safe and efficient helicopter transport of workers and equipment into the Owyhee River canyons.

\section{Environmental Setting}

The 5,005- $\mathrm{mi}^{2}$ study area is in Malheur County in southeastern Oregon and represents about 46 percent of the entire Owyhee River watershed. It lies within the Owyhee upland physiographic region, where elevations range from about 9,000 to about 2,500 ft above sea level at Lake Owyhee. The upper elevations of this region are characterized by granitic mountains that are partially covered with forest. The middle elevations are characterized by rhyolite and basalt in rolling plateaus, typically shallow soils, and shrub or grass cover. Most of the river flows through deep canyons that cannot be accessed by overland vehicles. Numerous geothermal springs discharge along the Owyhee River in several sections of the canyons.

Climate in the watershed is semiarid, and average annual precipitation is about $9.8 \mathrm{in} / \mathrm{yr}$, mostly as snow in the upper elevations. From 1961 to 1990 , yearly precipitation at the

Table 1. Description of sampling sites on the Owyhee River and selected tributaries, Oregon

[Site locations shown in figure 2; No., number; USGS, U.S. Geological Survey; ${ }^{\circ}$, degrees; ', minutes; ", seconds]

\begin{tabular}{|c|c|c|c|c|}
\hline Site No. & Site name & $\begin{array}{c}\text { USGS site } \\
\text { identification No. }\end{array}$ & Latitude & Longitude \\
\hline OR7 & Owyhee River at State Line near Three Forks $\ldots \ldots \ldots \ldots \ldots \ldots$ & 422015117024000 & $42^{\circ} 20^{\prime} 15^{\prime \prime}$ & $117^{\circ} 02^{\prime} 40^{\prime \prime}$ \\
\hline OR6 & Owyhee River above West Little Owyhee River. ... & 422650117121800 & $42^{\circ} 26 ' 50^{\prime \prime}$ & $117^{\circ} 12^{\prime} 18^{\prime \prime}$ \\
\hline WLO1 & West Little Owyhee River at mouth .......... & 422649117121900 & $42^{\circ} 26^{\prime} 49^{\prime \prime}$ & $117^{\circ} 12^{\prime} 19^{\prime \prime}$ \\
\hline OR5 & Owyhee River at Three Forks. & 13177900 & $42^{\circ} 32^{\prime} 40^{\prime \prime}$ & $117^{\circ} 10^{\prime} 11^{\prime \prime}$ \\
\hline NF1 & North Fork Owyhee River at mouth . & 13177920 & $42^{\circ} 32^{\prime} 39^{\prime \prime}$ & $117^{\circ} 10^{\prime} 06^{\prime \prime}$ \\
\hline OR4 & Owyhee River near Rome .................... & 425017117374900 & $42^{\circ} 50^{\prime} 17^{\prime \prime}$ & $117^{\circ} 37^{\prime} 49^{\prime \prime}$ \\
\hline $\mathrm{JC} 1$ & Jordan Creek near Rome . . . . . . . . . . . . . . . . . . . . . & 13180600 & $42^{\circ} 51^{\prime} 51^{\prime \prime}$ & $117^{\circ} 38^{\prime} 19^{\prime \prime}$ \\
\hline OR3 & 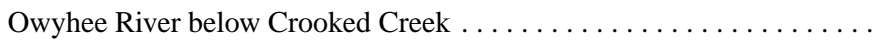 & 425442117432100 & $42^{\circ} 54^{\prime} 42^{\prime \prime}$ & $117^{\circ} 43^{\prime} 21^{\prime \prime}$ \\
\hline OR2 & Owyhee River above Bull Creek near Crowley. . . . . . . . . . . & 430631117425900 & $43^{\circ} 06^{\prime} 31^{\prime \prime}$ & $117^{\circ} 42^{\prime} 59^{\prime \prime}$ \\
\hline OR1 & Owyhee River above Lake Owyhee ............ & 13182000 & $43^{\circ} 13^{\prime} 34^{\prime \prime}$ & $117^{\circ} 29^{\prime} 46^{\prime \prime}$ \\
\hline
\end{tabular}


Rome weather station averaged 7.75 in., and mean monthly temperature ranged from $71.8^{\circ} \mathrm{F}\left(22.1^{\circ} \mathrm{C}\right)$ in July to $28.8^{\circ} \mathrm{F}$ $\left(1.7^{\circ} \mathrm{C}\right)$ in January. On the basis of data from the USGS gaging station operated from 1949 through 2002, stream discharge at the Owyhee River near Rome ranged from 42 to $55,700 \mathrm{ft}^{3} / \mathrm{s}$, and annual mean flow was $954 \mathrm{ft}^{3} / \mathrm{s}$.

More than 91 percent of the land cover is sagebrush shrubland and grassland (table 2). Vegetation along the river is generally too sparse to shade the water. The area is sparsely populated; most of the population and development are in the Rome area and near Jordan Creek and its tributaries. Primary historical and current land uses that may affect water quality are grazing, mining, and farming. Although livestock are grazed throughout the watershed, farming is concentrated in the Rome area and Jordan Creek Basin, and mining is concentrated in the Jordan Creek Basin (table 2). Historical gold and silver mining has caused significant mercury contamination in the Jordan Creek watershed (Koerber, 1995). This mining and naturally occurring cinnabar and geothermal springs contribute to the problem of mercury pollution and bioaccumulation by fish in the Owyhee Reservoir (Craft and others, 2000).

\section{Methods of Sample Collection and Analysis}

Ten sampling sites (fig. 2 and table 1) on the river and selected tributaries were chosen to represent stream quality at the upstream boundary of the BLM management unit and near major tributary confluences or areas of possible land-use impacts. Flow conditions representing summer base flow and spring runoff in 2001 were targeted for sampling to bracket a large range of flow conditions (fig. 3 ). Because of low runoff in 2001, spring runoff was sampled again in 2002 to provide a better approximation of normal runoff conditions.

A helicopter was used to gain access and transport boats and other equipment to 5 of the 10 sites. Sites OR5, NF1, OR4, JC1, and OR1 were visited by truck. In spring, travel to some of these sites was delayed until the remote dirt roads on the plateaus and steep roads into the canyons were passable. When transporting sampling personnel to new sites, helicopter pilots delivered samples from the previous site to runners who, in turn, arranged for delivery of samples for time-dependent analyses (such as nutrients and bacteria) to appropriate laboratories. The different methods used to access sites, variable flight schedules of helicopters, and weather-related delays for overland travel prevented sites from being sampled routinely in downstream order, and spring flow conditions sometimes changed significantly before all sites could be sampled. Because of these problems, an additional sample was collected at the bridge crossing at site OR4 during the 2002 spring runoff to capture a particularly high but short-term discharge. No bridges were located at the other sites, and safety risks were considered too great for sampling such high flows by using the inflatable watercraft that could be transported to these sites.

Table 2. Land use/cover and mineable deposits in the Owyhee River study area, Oregon

[Site locations shown in figure 2; No., number; $\mathrm{m}^{2}$, square miles; land use/cover in percent; land use/cover modified from the National Land Cover Dataset, 1992 (http://edc.usgs.gov/products/landcover.html)]

\begin{tabular}{|c|c|c|c|c|c|c|c|c|c|c|c|}
\hline Site No. & $\begin{array}{l}\text { Area } \\
\left(\mathrm{mi}^{2}\right)\end{array}$ & Water/lce & Forest & Shrubland & Grassland & Developed & Cultivated & Barren & Wetland & $\begin{array}{c}\text { No. of } \\
\text { significant } \\
\text { deposits }\end{array}$ & $\begin{array}{l}\text { No. of } \\
\text { significant } \\
\text { deposits } \\
\text { per } \mathrm{mi}^{2}\end{array}$ \\
\hline OR7 & 4,977 & 0.22 & 2.17 & 84.61 & 10.41 & 0.08 & 1.96 & 0.07 & 0.47 & 304 & 0.061 \\
\hline OR6 & 5,041 & .22 & 2.15 & 84.74 & 10.34 & .08 & 1.94 & .07 & .46 & 304 & .060 \\
\hline WLO1 & 310 & .09 & .35 & 96.55 & 2.84 & 0 & .01 & .14 & .01 & 1 & .003 \\
\hline OR5 & 5,723 & .20 & 1.92 & 85.00 & 9.85 & .07 & 2.46 & .08 & .41 & 306 & .053 \\
\hline NF1 & 335 & .36 & 25.77 & 68.16 & 4.98 & 0 & .37 & .02 & .33 & 0 & 0 \\
\hline OR4 & 6,401 & .22 & 3.13 & 84.08 & 9.48 & .07 & 2.53 & .08 & .42 & 310 & .048 \\
\hline $\mathrm{JC} 1$ & 1,273 & .66 & 15.50 & 65.71 & 7.74 & .21 & 5.57 & 3.48 & 1.13 & 162 & .127 \\
\hline OR3 & 9,072 & .25 & 4.39 & 82.23 & 8.97 & .09 & 3.02 & .58 & .46 & 493 & .054 \\
\hline OR2 & 9,433 & .25 & 4.23 & 82.37 & 8.99 & .09 & 2.91 & .71 & .46 & 496 & .053 \\
\hline OR1 & 9,982 & .23 & 4.00 & 82.73 & 8.98 & .08 & 2.79 & .68 & .49 & 503 & .050 \\
\hline
\end{tabular}




\section{EXPLANATION}

$\triangle 0 R 1$ Sampling site and identification number-site descriptions shown in table 1
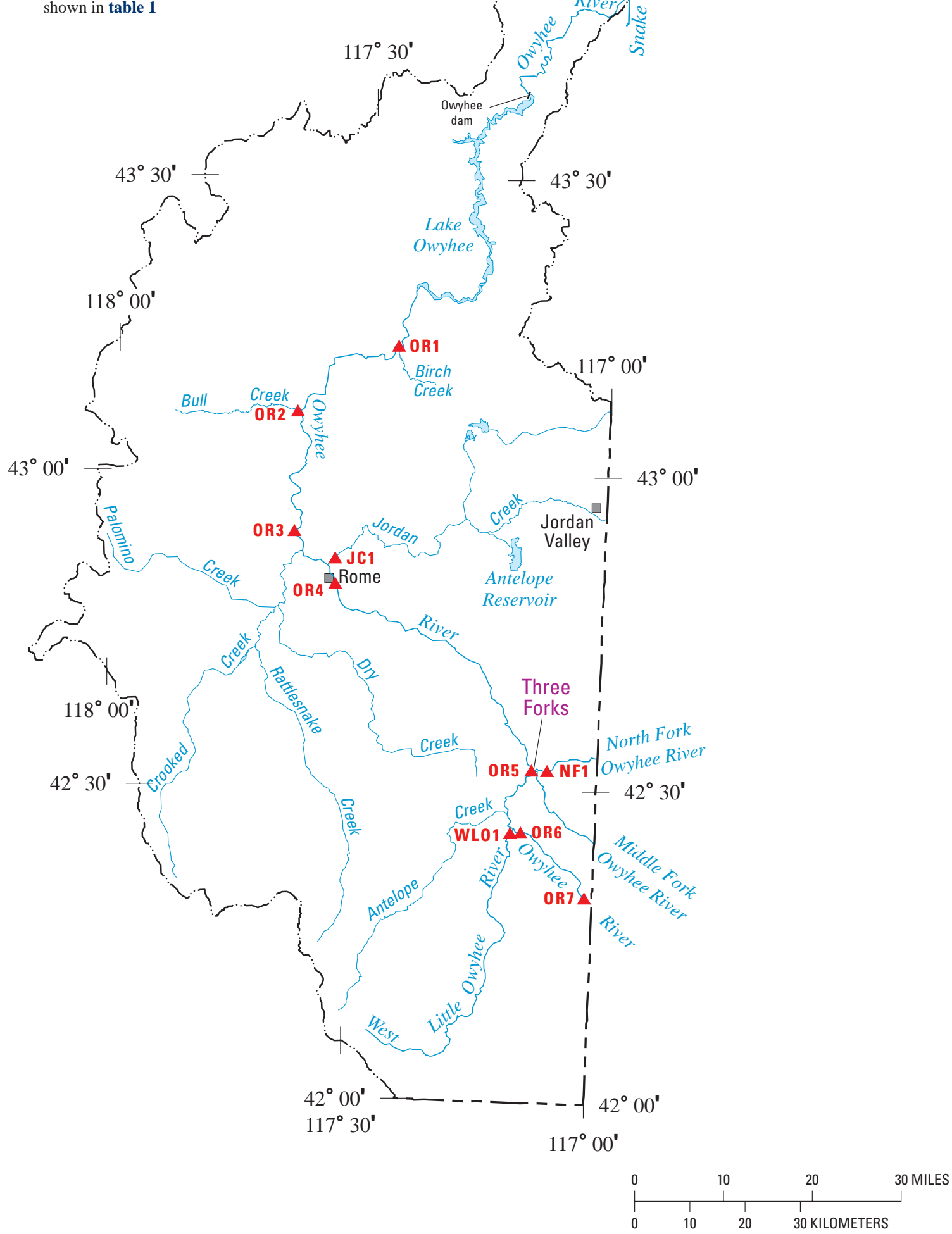

Figure 2. Location of sampling sites in the Owyhee River study area, Oregon. 


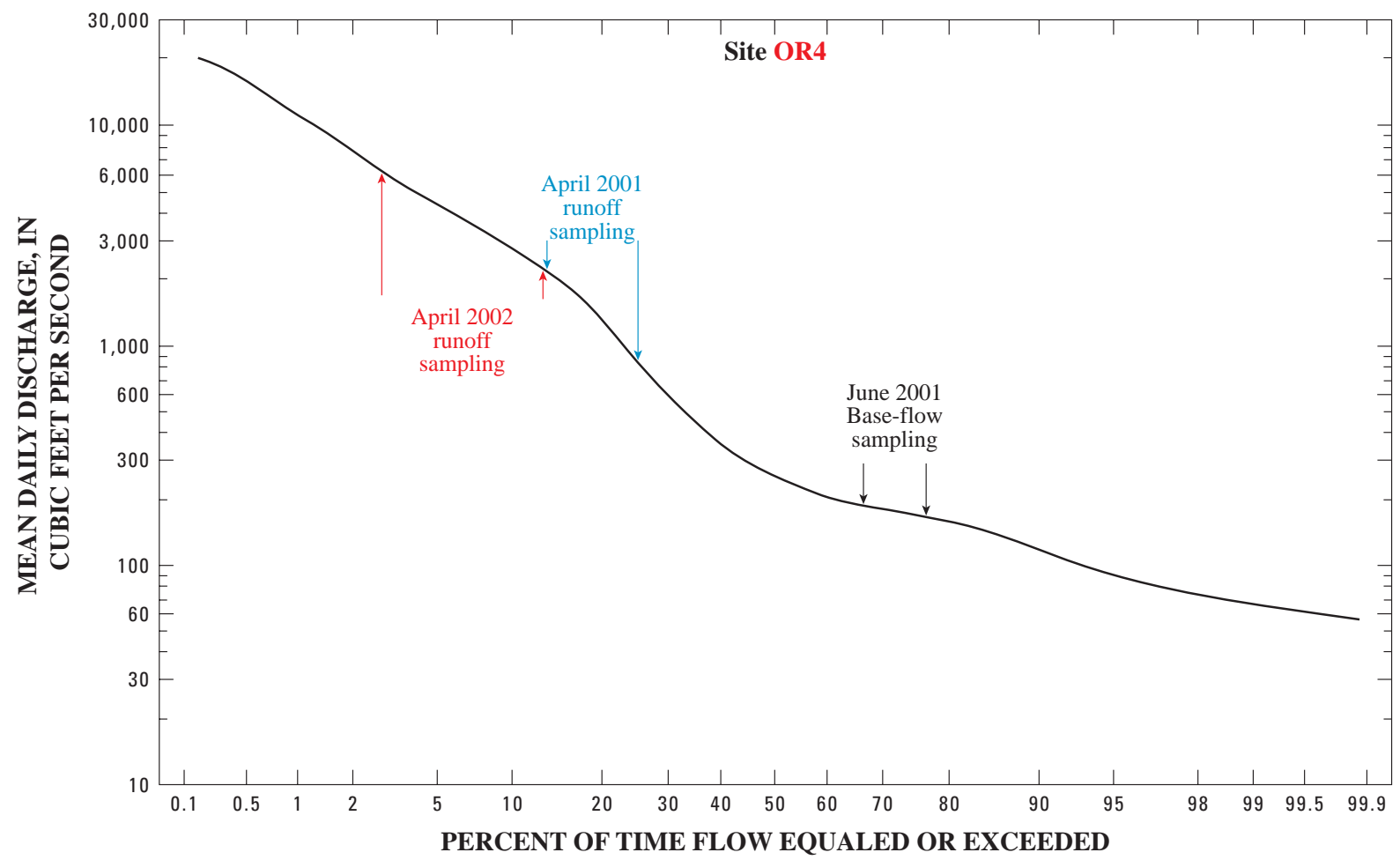

Figure 3. Flow-duration curve for 1949-2002 and sampling periods for the Owyhee River near Rome, Oregon, site OR4. (Site location shown in figure 2)

\section{Water and Stream-Bottom Samples}

Water samples for analyses of chemical constituents and suspended sediment were collected and processed using depth-integrating samplers, the equal-width-increment method, and a modified clean-sampling procedure described by Wilde and others (1999). At the time of sample collections, temperature, $\mathrm{pH}$, dissolved oxygen, and specific conductance were measured instream at the center of flow by using calibrated electrometric meters. In addition, when each site was sampled, stream discharge was measured using either a Price AA or pygmy current meter or an Acoustic Doppler Current Profiler (ADCP). All samples analyzed for "dissolved" constituents were filtered through $0.45-\mu \mathrm{m}$ capsule filters that are certified to be free from contamination. Suspended sediment was analyzed at the USGS Sediment Laboratory at Vancouver, Washington, by using the methods of Guy (1969). Chemical constituents in water were analyzed at the USGS National Water Quality Laboratory (NWQL) by using the methods of Fishman and Friedman (1989) and Fishman (1993).

Samples for analyses of $E$. coli bacteria were collected instream at the center of flow by using sterilized bottles. The samples were analyzed at the Idaho State Department of Welfare, Bureau of Laboratories, by using the Colilert Quantitray method (a most-probable-number technique) described by the American Public Health Association (1998).
Silt- and clay-sized stream-bottom samples were collected and sieved during summer base flow by the methods described by Radtke (1997). Particles less than $62.5 \mu \mathrm{m}$ in diameter were isolated for analysis by sieving through nonmetallic sieves using native river water. All samples were analyzed at the USGS Environmental Geochemistry Laboratory by using a complete-digestion method described by Briggs and Meier (1999).

Hourly water-temperature data from April through September 2001 were collected by deploying calibrated, selflogging microthermistors. The thermistors were deployed after elevated spring runoff had subsided to ensure that the equipment would remain submerged during summer base flow.

\section{Biological Community Samples}

Benthic invertebrate communities were sampled during base flow conditions from June 25 through July 11, 2001. Five riffle areas were selected at each site and sampled using a Slack rectangular kick-net sampler equipped with a $425-\mu \mathrm{m}$ mesh net (Cuffney and others, 1993). At each riffle, large gravel and cobbles within a $0.25-\mathrm{m}^{2}$ sample area in front of the net were brushed to dislodge organisms. The sample area then was disturbed by kicking in the loose gravels for $30 \mathrm{sec}-$ onds. Each sample was elutriated onsite by repeated washing into a $425-\mu \mathrm{m}$ mesh sieve. After processing, the five samples 
were composited (total sample area of $1.25 \mathrm{~m}^{2}$ ) in 1-L plastic jars, fixed with 10 percent buffered formalin, and shipped to EcoAnalysts in Moscow, Idaho, for taxonomic processing. At EcoAnalysts, samples were sorted and organisms were identified and counted to the lowest practical taxonomic level (genus or species for most taxa).

Semiquantitative epilithic periphyton samples were collected and processed using protocols developed by the USGS National Water-Quality Assessment (NAWQA) Program to estimate and compare biomass chlorophyll- $a$ and ash-free dry weight among sites (Porter and others, 1993). Epilithic periphyton samples were collected adjacent to each of the five benthic invertebrate sample locations. Five rocks were sampled at each site by using a 30-mL syringe fitted with an O-ring to form a watertight seal against a rock surface. Periphyton within the syringe barrel were dislodged with a small brush and collected with a hand pipette. Samples were composited into a sample jar and stirred, and an aliquot of $10 \mathrm{~mL}$ was filtered through a $0.7-\mu \mathrm{m}$ glass-fiber filter. Filters were wrapped in aluminum foil, placed in a glass vial, and frozen until they were processed at the Bureau of Reclamation Pacific Northwest Regional Laboratory in Boise, Idaho. Biomass and chlorophyll- $a$ were determined following procedures described by the American Public Health Association (1995). Chlorophyll- $a$ concentrations were determined using spectrophotometry and corrected for phaeophytin, a degradation product of chlorophyll.

Microhabitat data were collected at each site where invertebrates and periphyton were collected following procedures outlined by Fitzpatrick and others (1998). Depth, velocity, and percent open canopy were measured. Velocities were measured at 0.6 of the stream depth using a Marsh-McBirney flowmeter. Percent open canopy was measured using a clinometer to measure left and right angles above horizon obstructions. Dominant substrate, percent substrate fines, and percent filamentous algae coverage were estimated visually to the nearest 10 percent. Percent substrate embeddedness was categorized into one of five groups as outlined by Fitzpatrick and others (1998). A mean value for each habitat variable was calculated to represent a riffle sample site.

\section{Quality Assurance}

Temperature, $\mathrm{pH}$, dissolved oxygen, and specific conductance were measured at the center of flow where the stream appeared to be well mixed. At seven sites, measurements were made at five sections across the stream to determine whether properties in some parts of the stream might differ significantly from those in the center of flow. In these cross sections, values of $\mathrm{pH}$ always agreed to within 0.1 unit, temperatures always agreed to within $0.3^{\circ} \mathrm{C}$, and specific conductance values always agreed within $1 \mu \mathrm{S} / \mathrm{cm}$. At all but one site, dissolved oxygen concentrations agreed to within $0.07 \mathrm{mg} / \mathrm{L}$. Variation of dissolved oxygen concentrations across Jordan Creek was $0.9 \mathrm{mg} / \mathrm{L}$ (or less than 8 percent of the $11.4 \mathrm{mg} / \mathrm{L}$ at the center of flow) in April 2001. These data indicate that onsite measurements made at the center of flow closely repre- sented the conditions in the entire cross section. Because samples were collected using depth- and width-integrating techniques, water-chemistry analyses were not affected significantly by stream cross-section variations.

Extensive quality control procedures used at NWQL and USGS Environmental Geochemistry Laboratory included verifying the condition of reagents and equipment, managing samples, participating in internal and external performance evaluation studies, internal and external audits, data verifications, protocols for continuously monitoring quality control data, and chemical logic checks. These procedures are summarized in reports by Pritt and Raese (1995), Friedman and Erdmann (1982), and Arbogast (1990). Most chemical logic checks met data requirements. Cation-anion balances were all within 5 percent, and only one analysis reported a dissolved organic plus ammonium nitrogen concentration higher than the total organic plus ammonium nitrogen concentration (see the June 2001 sample for site OR4 in table 3, back of report). This discrepancy was within the criteria established for variation of duplicate samples (explained in the following paragraphs) and, therefore, was considered acceptable.

In addition to these laboratory procedures, blank and duplicate samples were submitted to the NWQL. One field blank sample was collected at streamside during each of the three sampling events in April and June 2001 and April 2002 to help verify that sampling environment, equipment, and processing were not significantly contaminating samples. Samples were collected by passing about $2 \mathrm{~L}$ of certified analytefree water through all sampling and processing equipment used for routine sample collection. The samples were analyzed for major ions, nutrients, arsenic, and selenium. Results for all analyses were below laboratory reporting limits, except for a calcium detection of $0.022 \mathrm{mg} / \mathrm{L}$. This concentration is nearly 190 times lower than the lowest calcium concentration measured during the reconnaissance. These results indicate that sampling environment, equipment, and processing did not significantly contaminate environmental samples.

Six pairs of duplicate samples were collected and submitted to the laboratory for analysis of major ions, nutrients, arsenic, and selenium (table 4). Duplicate sample analyses were considered acceptable if the relative percent difference $(\mathrm{RPD}=\{|\mathrm{S}-\mathrm{D}| /[(\mathrm{S}+\mathrm{D}) / 2]\} \times 100$; where $\mathrm{S}=$ result of sample analysis and $\mathrm{D}=$ result of duplicate sample analysis) met the following criteria:

\begin{tabular}{c|c}
\hline \multicolumn{1}{c|}{ Sample concentration } & Maximum allowed variation \\
\hline $0-5$ times reporting limit & $+(-) 1$ reporting limit \\
\hline$>5-20$ times reporting limit & $\begin{array}{c}\text { Greater of } 2 \text { reporting limits } \\
\text { or } 20 \text { percent RPD }\end{array}$ \\
\hline$>20$ times reporting limit & 10 percent RPD \\
\hline
\end{tabular}

All duplicate chemical analyses met these criteria, which suggests that analytical data were of high precision. 
Table 4. Chemical analyses of duplicate water samples collected from the Owyhee River and selected tributaries, Oregon, 2001 and 2002

[Site locations shown in figure 2 No., number; fltrd, filtered; mg/L, milligrams per liter; $\mathrm{ANC}$, acid neutralizing capacity; unfltrd, unfiltered; pt, point; $\mathrm{CaCO}_{3}$, calcium carbonate; org-N, organic nitrogen; $\mathrm{P}$, phosphorus; $\mu \mathrm{g} / \mathrm{L}$, micrograms per liter; <, less than; E, estimated value]

\begin{tabular}{|c|c|c|c|c|c|c|c|c|c|c|c|c|}
\hline $\begin{array}{l}\text { Site } \\
\text { No. }\end{array}$ & Date & Time & $\begin{array}{c}\text { Calcium, } \\
\text { water, } \\
\text { fltrd, } \\
\text { mg/L } \\
\text { (00915) }\end{array}$ & $\begin{array}{l}\text { Magnesium, } \\
\text { water, } \\
\text { fltrd, } \\
\mathrm{mg} / \mathrm{L} \\
(00925)\end{array}$ & $\begin{array}{l}\text { Potassium, } \\
\text { water, } \\
\text { fltrd, } \\
\text { mg/L } \\
(00935)\end{array}$ & $\begin{array}{c}\text { Sodium, } \\
\text { water, } \\
\text { fltrd, } \\
\text { mg/L } \\
(00930)\end{array}$ & $\begin{array}{l}\text { ANC, water, unfltrd, } \\
\text { fixed end pt, lab, } \\
\text { mg/L as CaCO3 } \\
\text { (90410) }\end{array}$ & $\begin{array}{c}\text { Chloride, } \\
\text { water, } \\
\text { fltrd, } \\
\mathrm{mg} / \mathrm{L} \\
(00940)\end{array}$ & $\begin{array}{c}\text { Fluoride, } \\
\text { water, } \\
\text { fltrd, } \\
\text { mg/L } \\
(00950)\end{array}$ & $\begin{array}{c}\text { Silica, } \\
\text { water, } \\
\text { fltrd, } \\
\mathrm{mg} / \mathrm{L} \\
(\mathbf{0 0 9 5 5 )}\end{array}$ & $\begin{array}{c}\text { Sulfate, } \\
\text { water, } \\
\text { fltrd, } \\
\mathrm{mg} / \mathrm{L} \\
(00945)\end{array}$ & $\begin{array}{c}\text { Residue, } \\
\text { water, fltrd, } \\
\text { sum of constituents } \\
\mathrm{mg} / \mathrm{L} \\
(70301)\end{array}$ \\
\hline OR7 & $06-27-01$ & $\begin{array}{l}0820 \\
0815\end{array}$ & $\begin{array}{l}23.4 \\
23.7\end{array}$ & $\begin{array}{l}8.64 \\
8.71\end{array}$ & $\begin{array}{l}5.14 \\
4.91\end{array}$ & $\begin{array}{l}30.4 \\
30.7\end{array}$ & $\begin{array}{l}137 \\
137\end{array}$ & $\begin{array}{l}8.12 \\
8.21\end{array}$ & $\begin{array}{l}1.8 \\
1.8\end{array}$ & $\begin{array}{l}19.3 \\
19.2\end{array}$ & $\begin{array}{l}14.8 \\
14.7\end{array}$ & $\begin{array}{l}194 \\
194\end{array}$ \\
\hline OR6 & 04-15-02 & $\begin{array}{l}1610 \\
1605\end{array}$ & $\begin{array}{l}11.6 \\
11.7\end{array}$ & $\begin{array}{l}2.93 \\
2.97\end{array}$ & $\begin{array}{l}2.53 \\
2.45\end{array}$ & $\begin{array}{l}9.05 \\
9.25\end{array}$ & $\begin{array}{l}52 \\
53\end{array}$ & $\begin{array}{l}3.75 \\
3.93\end{array}$ & $\begin{array}{l}.5 \\
.6\end{array}$ & $\begin{array}{l}23.4 \\
23.1\end{array}$ & $\begin{array}{l}6.8 \\
6.8\end{array}$ & $\begin{array}{l}92 \\
93\end{array}$ \\
\hline WLO1 & 04-10-01 & $\begin{array}{l}1455 \\
1450\end{array}$ & $\begin{array}{l}8.15 \\
8.11\end{array}$ & $\begin{array}{l}2.19 \\
2.18\end{array}$ & $\begin{array}{l}1.86 \\
1.78\end{array}$ & $\begin{array}{l}8.87 \\
8.88\end{array}$ & $\begin{array}{l}39 \\
39\end{array}$ & $\begin{array}{l}5.07 \\
4.70\end{array}$ & $\begin{array}{l}.3 \\
.3\end{array}$ & $\begin{array}{l}15.9 \\
15.8\end{array}$ & $\begin{array}{l}5.6 \\
5.5\end{array}$ & $\begin{array}{l}71 \\
71\end{array}$ \\
\hline NF1 & 04-11-02 & \begin{tabular}{|l|}
1405 \\
1400
\end{tabular} & $\begin{array}{l}4.30 \\
4.11\end{array}$ & $\begin{array}{l}1.73 \\
1.67\end{array}$ & $\begin{array}{l}1.25 \\
1.29\end{array}$ & $\begin{array}{l}3.34 \\
3.22\end{array}$ & $\begin{array}{l}25 \\
25\end{array}$ & $\begin{array}{l}.90 \\
.84\end{array}$ & $\begin{array}{l}\text { E.1 } \\
\text { E.1 }\end{array}$ & $\begin{array}{l}24.6 \\
24.6\end{array}$ & $\begin{array}{l}1.4 \\
1.3\end{array}$ & $\begin{array}{l}53 \\
52\end{array}$ \\
\hline OR4 & 04-04-01 & $\begin{array}{l}1245 \\
1250\end{array}$ & $\begin{array}{l}14.3 \\
14.3\end{array}$ & $\begin{array}{l}3.74 \\
3.71\end{array}$ & $\begin{array}{l}2.41 \\
2.38\end{array}$ & $\begin{array}{l}12.0 \\
11.9\end{array}$ & $\begin{array}{l}61 \\
62\end{array}$ & $\begin{array}{l}3.92 \\
3.95\end{array}$ & $\begin{array}{l}.7 \\
.7\end{array}$ & $\begin{array}{l}25.2 \\
25.0\end{array}$ & $\begin{array}{l}8.6 \\
8.7\end{array}$ & $\begin{array}{l}108 \\
108\end{array}$ \\
\hline OR2 & $06-28-01$ & $\begin{array}{l}1220 \\
1215\end{array}$ & $\begin{array}{l}20.8 \\
21.0\end{array}$ & $\begin{array}{l}5.95 \\
5.99\end{array}$ & $\begin{array}{l}4.77 \\
4.81\end{array}$ & $\begin{array}{l}41.5 \\
40.7\end{array}$ & $\begin{array}{l}129 \\
129\end{array}$ & $\begin{array}{l}11.3 \\
11.2\end{array}$ & $\begin{array}{l}2.0 \\
2.0\end{array}$ & $\begin{array}{l}32.5 \\
32.3\end{array}$ & $\begin{array}{l}23.6 \\
23.8\end{array}$ & $\begin{array}{l}221 \\
221\end{array}$ \\
\hline
\end{tabular}

\begin{tabular}{|c|c|c|c|c|c|c|c|c|c|c|c|c|c|}
\hline $\begin{array}{l}\text { Site } \\
\text { No. }\end{array}$ & Date & Time & $\begin{array}{c}\text { Ammonia + } \\
\text { org-N, } \\
\text { water, fltrd, } \\
\text { mg/L as N } \\
\text { (00623) }\end{array}$ & $\begin{array}{c}\text { Ammonia + } \\
\text { org-N, } \\
\text { water, unfltrd, } \\
\text { mg/L as N } \\
(00625)\end{array}$ & $\begin{array}{c}\text { Ammonia, } \\
\text { water, fltrd, } \\
\mathrm{mg} / \mathrm{L} \text { as N } \\
(00608)\end{array}$ & $\begin{array}{c}\text { Nitrite + } \\
\text { nitrate, } \\
\text { water, fltrd, } \\
\text { mg/L as N } \\
\text { (00631) }\end{array}$ & $\begin{array}{c}\text { Nitrite, } \\
\text { water, fltrd, } \\
\text { mg/L as N } \\
\text { (00613) }\end{array}$ & $\begin{array}{c}\text { Orthophos- } \\
\text { phate, } \\
\text { water, fltrd, } \\
\text { mg/L as P } \\
\text { (00671) }\end{array}$ & $\begin{array}{c}\text { Phosphorus, } \\
\text { water, unfltrd, } \\
\mathrm{mg} / \mathrm{L} \\
(\mathbf{0 0 6 6 5 )}\end{array}$ & $\begin{array}{c}\text { Arsenic, } \\
\text { water, fltrd, } \\
\mu \mathrm{g} / \mathrm{L} \\
(01000)\end{array}$ & $\begin{array}{c}\text { Arsenic, } \\
\text { water, } \\
\text { unfltrd, } \\
\mu \mathrm{g} / \mathrm{L} \\
(\mathbf{0 1 0 0 2 )}\end{array}$ & $\begin{array}{c}\text { Selenium, } \\
\text { water, fltrd, } \\
\mu \mathrm{g} / \mathrm{L} \\
(\mathbf{0 1 1 4 5 )}\end{array}$ & $\begin{array}{c}\text { Selenium, } \\
\text { water, } \\
\text { unfltrd, } \\
\mu \mathrm{g} / \mathrm{L} \\
(\mathbf{0 1 1 4 7 )}\end{array}$ \\
\hline OR7 & $06-27-01$ & \begin{tabular}{|l|}
0820 \\
0815
\end{tabular} & $\begin{array}{r}0.29 \\
.28\end{array}$ & $\begin{array}{r}0.34 \\
.34\end{array}$ & $\begin{array}{l}\text { E.03 } \\
\text { E.03 }\end{array}$ & $\begin{array}{r}<0.05 \\
<.05\end{array}$ & $\begin{array}{r}0.009 \\
.008\end{array}$ & $\begin{array}{r}\text { E0.01 } \\
<.02\end{array}$ & $\begin{array}{r}<0.06 \\
<.06\end{array}$ & $\begin{array}{l}6 \\
6\end{array}$ & $\begin{array}{l}6 \\
6\end{array}$ & $\begin{array}{l}<2 \\
<2\end{array}$ & $\begin{array}{l}<3 \\
<3\end{array}$ \\
\hline OR6 & 04-15-02 & \begin{tabular}{|l|}
1610 \\
1605
\end{tabular} & $\begin{array}{l}.31 \\
.32\end{array}$ & $\begin{array}{l}.48 \\
.49\end{array}$ & $\begin{array}{l}<.04 \\
<.04\end{array}$ & $\begin{array}{l}.07 \\
.07\end{array}$ & $\begin{array}{l}<.008 \\
<.008\end{array}$ & $\begin{array}{l}.03 \\
.03\end{array}$ & $\begin{array}{l}.09 \\
.08\end{array}$ & $\begin{array}{l}2 \\
3\end{array}$ & $\begin{array}{l}3 \\
3\end{array}$ & $\begin{array}{l}<2 \\
<2\end{array}$ & $\begin{array}{l}<2 \\
<2\end{array}$ \\
\hline WLO1 & 04-10-01 & \begin{tabular}{|l|}
1455 \\
1450
\end{tabular} & $\begin{array}{l}\text { E.09 } \\
\text { E.10 }\end{array}$ & $\begin{array}{l}.15 \\
.18\end{array}$ & $\begin{array}{l}<.04 \\
<.04\end{array}$ & $\begin{array}{l}<.05 \\
<.05\end{array}$ & $\begin{array}{l}<.006 \\
<.006\end{array}$ & $\begin{array}{l}\text { E.02 } \\
\text { E.02 }\end{array}$ & $\begin{array}{l}\text { E.03 } \\
\text { E.03 }\end{array}$ & $\begin{array}{l}\text { E1 } \\
\text { E1 }\end{array}$ & $\begin{array}{l}\text { E1 } \\
\text { E1 }\end{array}$ & $\begin{array}{l}<2 \\
<2\end{array}$ & $\begin{array}{l}<3 \\
<3\end{array}$ \\
\hline NF1 & 04-11-02 & \begin{tabular}{|l|}
1405 \\
1400
\end{tabular} & $\begin{array}{l}.22 \\
.17\end{array}$ & $\begin{array}{l}.31 \\
.33\end{array}$ & $\begin{array}{l}<.04 \\
<.04\end{array}$ & $\begin{array}{l}.08 \\
.08\end{array}$ & $\begin{array}{l}<.008 \\
<.008\end{array}$ & $\begin{array}{l}\text { E.01 } \\
\text { E.01 }\end{array}$ & $\begin{array}{l}\text { E.05 } \\
\text { E.05 }\end{array}$ & $\begin{array}{l}<2 \\
<2\end{array}$ & $\begin{array}{l}<2 \\
<2\end{array}$ & $\begin{array}{l}<2 \\
<2\end{array}$ & $\begin{array}{l}<2 \\
<2\end{array}$ \\
\hline OR4 & 04-04-01 & \begin{tabular}{|l|}
1245 \\
1250
\end{tabular} & $\begin{array}{l}.20 \\
.20\end{array}$ & $\begin{array}{l}.40 \\
.37\end{array}$ & $\begin{array}{l}<.04 \\
<.04\end{array}$ & $\begin{array}{l}.10 \\
.10\end{array}$ & $\begin{array}{l}<.006 \\
<.006\end{array}$ & $\begin{array}{r}.02 \\
\text { E.02 }\end{array}$ & $\begin{array}{l}\text { E.04 } \\
\text { E.05 }\end{array}$ & $\begin{array}{l}3 \\
3\end{array}$ & $\begin{array}{l}3 \\
3\end{array}$ & $\begin{array}{l}<2 \\
<2\end{array}$ & $\begin{array}{l}<3 \\
<3\end{array}$ \\
\hline OR2 & 06-28-01 & \begin{tabular}{|l|}
1220 \\
1215
\end{tabular} & $\begin{array}{l}.23 \\
.22\end{array}$ & $\begin{array}{l}.33 \\
.30\end{array}$ & $\begin{array}{l}\text { E.02 } \\
\text { E.02 }\end{array}$ & $\begin{array}{l}.30 \\
.30\end{array}$ & $\begin{array}{l}.010 \\
.010\end{array}$ & $\begin{array}{l}<.02 \\
<.02\end{array}$ & $\begin{array}{l}\text { E.04 } \\
<.06\end{array}$ & $\begin{array}{l}11 \\
11\end{array}$ & $\begin{array}{l}10 \\
10\end{array}$ & $\begin{array}{l}<2 \\
<2\end{array}$ & $\begin{array}{l}<3 \\
<3\end{array}$ \\
\hline
\end{tabular}


A duplicate benthic invertebrate sample was collected using a 300-subsample count method (Moulton and others, 2000) at site OR6 and submitted to the USGS Biological Unit, Denver. Total abundance was comparable $-14,833$ to 17,449 individuals $/ \mathrm{m}^{2}$. However, only 22 taxa were common between both samples. Of the 64 distinct taxa identified by both laboratories, 41 and 46 taxa were identified by the contract and the USGS laboratories, respectively. Eleven taxa identified by the USGS laboratory were not identified by the contract laboratory in any of the other invertebrate samples collected during this study. These results are consistent with an interlaboratory comparison by Maret and others (2001) that also revealed large differences between invertebrate contract laboratories and suggest that use of the same laboratory for routine biological monitoring and assessment programs is necessary to ensure analytical consistency.

A duplicate periphyton community sample was collected to evaluate variation in chlorophyll- $a$ concentration and biomass. Chlorophyll- $a$ concentrations for the duplicate samples were 40 and $52 \mathrm{mg} / \mathrm{m}^{2}$ (RPD of 26 percent), and biomass concentrations were 18 and $34 \mathrm{~g} / \mathrm{m}^{2}$ (RPD of 61 percent). These are normal variations for filamentous algae samples and are caused primarily by difficulties in homogenizing such samples.

\section{Chemical and Biological Quality}

\section{Water Temperature}

Temperature is a property of water that affects the entire river ecosystem, and increases in stream temperatures are known to adversely affect some communities. Concentrations of other regulated water-quality parameters, such as dissolved oxygen and un-ionized ammonia, also affect stream biota and are dependent on water temperature. Despite maximum watertemperature criteria that have been established for many streams, recent data show that temperatures of streams not significantly influenced by human activities may naturally exceed these criteria and still support healthy biological communities (Essig, 1998).

Continuous water-temperature data were collected from the Owyhee River and selected tributaries from April through September 2001 (fig. 4). Data for site OR5 are missing because the deployed instrument was vandalized. Temperatures were highest in early July through early August and lowest in late September. Maximum temperatures ranged from $25.1^{\circ}$ to $30.9^{\circ} \mathrm{C}$, and maximum 7 -day average temperatures ranged from $24.2^{\circ}$ to $28.9^{\circ} \mathrm{C}$. These temperatures exceeded Oregon's recommended maximum temperature of $17.8^{\circ} \mathrm{C}$ for water that supports salmonid fish rearing (Oregon Department of Environmental Quality, 2002). These high water temperatures probably explain the absence or low abundance of coldwater invertebrate taxa in the study area (see section, "Benthic Invertebrates"). Summer temperatures generally were highest in the central part of the study area (sites NF1, OR4, and JC1) and just upstream from Lake Owyhee (site OR1). The increases in minimum temperatures at sites OR2 and OR1 imply that geothermal inputs, reradiation from canyon walls, or other factors could affect stream temperatures in the lower reaches of the study area. The missing data at site OR5 might have given insight into effects from upstream geothermal springs. Collecting continuous temperature throughout cold seasons might help better define the influence of geothermal springs on Owyhee River temperatures.

\section{Suspended Sediment and Turbidity}

Suspended sediment in streams is fragmentary material that originates mostly from weathering of rocks. Because certain contaminants such as some trace elements and pesticides preferentially partition onto sediment, their distribution through the watershed often is controlled primarily by sediment transport, and their exposure to biota is most significant in zones where the sediment accumulates. In addition to contaminant transport, high concentrations of suspended sediment can affect stream communities by reducing light penetration and increasing scouring action. When stream discharges wane, large amounts of suspended sediment can settle and suffocate bottom-dwelling organisms. Delivery of fluvial sediment into reservoirs also results in accumulations that reduce reservoir volumes.

Suspended sediment concentrations at all sites were higher during spring runoff than during base flow (fig. 5), owing to resuspension and transport of particulate and streambottom materials during increased stream velocities and to additional particulate materials from overland runoff and bank erosion. During base flow, concentrations were less than 10 $\mathrm{mg} / \mathrm{L}$ at all sites. During the 2001 spring runoff, concentrations were 52 and $41 \mathrm{mg} / \mathrm{L}$ at sites OR5 and JC1 and less than $20 \mathrm{mg} / \mathrm{L}$ at all other sites. During the 2002 spring runoff, distributions of suspended sediment concentrations upstream from site OR4 were similar to those during the 2001 runoff. However, lower basin concentrations at sites OR4, JC1, OR3, and OR2 during this period commonly exceeded $50 \mathrm{mg} / \mathrm{L}$ and were as high as $142 \mathrm{mg} / \mathrm{L}$ at site OR3, below Crooked Creek.

Sediment concentrations can vary widely during runoff events, so individual samples may not represent the most extreme concentrations. For the 2002 spring runoff event, flow was highest before the canyon could be accessed by helicopter on April 15. In an attempt to measure the highest flow possible, samples were collected on April 3 at site OR4, the only site in the study area with a bridge crossing. Suspended sediment in this sample was more than 5 times higher $(134 \mathrm{mg} / \mathrm{L})$ than that in the April 12 sample. Streamflow on April 3 was $5,490 \mathrm{ft}^{3} / \mathrm{s}$, representing flows exceeded about 4 percent of the time; streamflow on April 12 was 2,510 $\mathrm{ft}^{3} / \mathrm{s}$, representing flows exceeded about 10 percent of the time (fig. 3). As a result, it is likely that the spring runoff samples collected at several other sites do not represent the highest concentrations of suspended sediment that occurred at those sites.

Instantaneous loads of sediment in the Owyhee River were highest during the 2002 spring runoff in the lower basin 


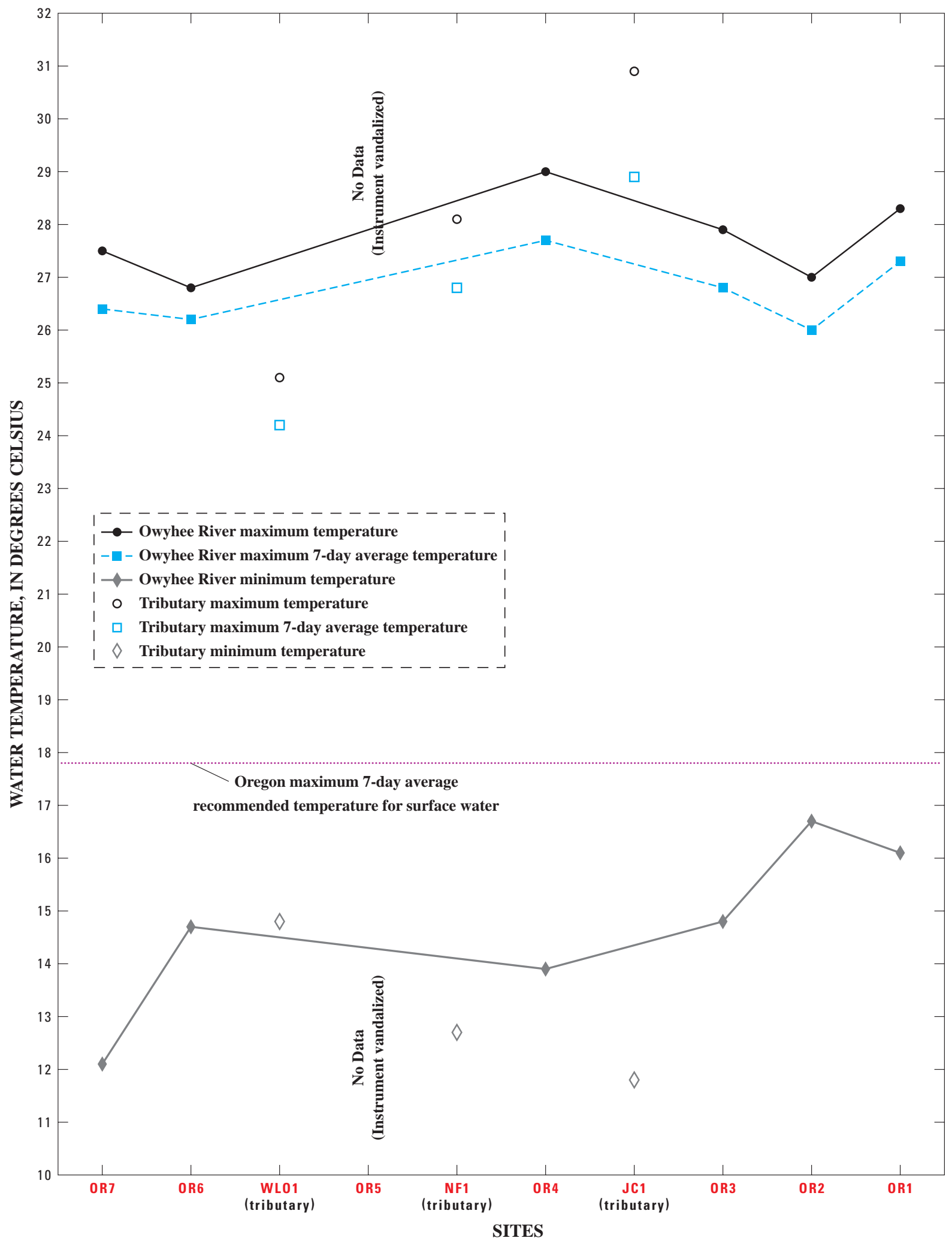

Figure 4. Water temperature in the Owyhee River and selected tributaries, Oregon, April through September 2001. (Site locations shown in figure 2) 

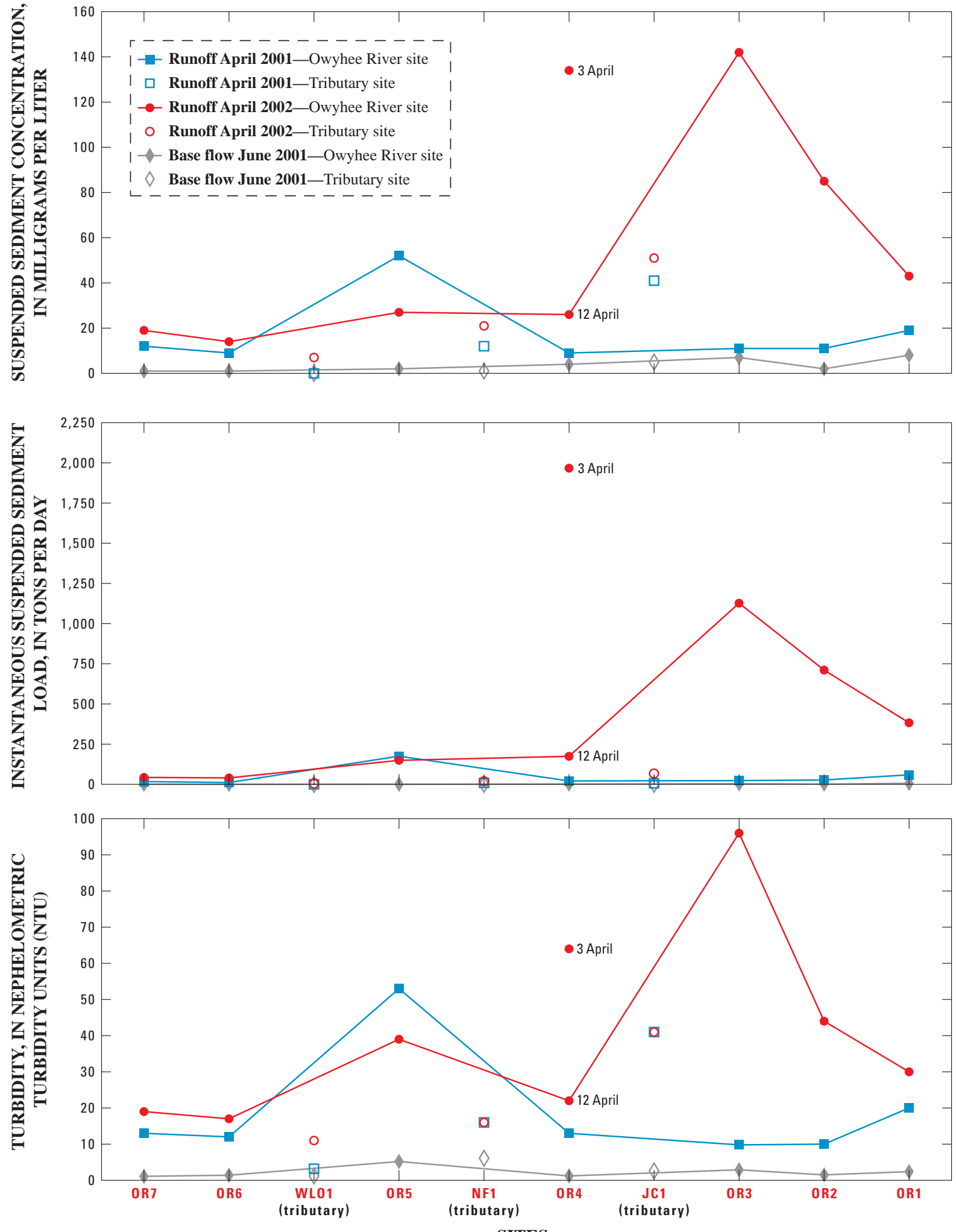

SITES

Figure 5. Suspended sediment concentrations, instantaneous loads, and turbidity in the Owyhee River and selected tributaries, Oregon, 2001 and 2002. (Site locations shown in figure 2) 
at sites OR3, OR2, and OR1; loads discharged by tributaries WLO1, NF1, and JC1 did not contribute significantly to Owyhee River loads (fig. 5). It is not known whether the large sediment loads in the lower basin in 2002 were the result of increased stream-channel scouring, or whether some unique event such as bank caving may have caused an abnormally high rate of sediment recruitment.

Turbidity, an optical measurement of light scattering, sometimes is used as a low-cost surrogate for monitoring suspended sediment. In addition to suspended sediment, turbidity measurements are affected by phytoplankton populations, water color, sediment color, and other factors. Increases in turbidity during spring runoff between sites OR6 and OR5, and between OR4 and OR3 (fig. 5) exceeded Oregon's recommended 10-percent cumulative increase. As discussed previously, the sources of sediment that probably caused these turbidity increases are unknown but may have been the result of natural processes during high flows of fairly short duration. The spatial and temporal variations for turbidity measurements were similar to those for suspended sediment concentrations (fig. 5), which suggests that turbidity measurements could be an effective method for monitoring sediment in the Owyhee River. Recent development of a variety of instream instruments has allowed effective continuous monitoring and real-time reporting of turbidity measurements. However, turbidity measurement methods vary enough that they often cannot be compared (even if they are reporting the same measurement units), and the instream instruments make measurements only at a single point in the stream. As a result, a relation between USGS laboratory turbidity measurements (of integrated samples) and sediment concentrations was not developed for this reconnaissance because the relation probably could not be applied to measurements made by the typical instream methods.

\section{Dissolved Oxygen}

Nearly all stream fauna depend on adequate dissolved oxygen, though different organisms have different minimum requirements. Generally, reproducing salmonid fishes have some of the highest dissolved oxygen requirements. Oxygen solubility in water is inversely related to temperature, so that at high temperatures, the saturated dissolved oxygen concentrations may be far lower than those at cold temperatures. Oxygen dissolves in water primarily by dissolution from the atmosphere in turbulent stream zones and by photosynthesis by suspended and attached algal communities. During daylight, dissolved oxygen concentrations can become supersaturated as a result of algal photosynthesis. Respiration by stream organisms and decomposition of organic materials are two major ways that dissolved oxygen is depleted in water.

Excluding a concentration of $4.7 \mathrm{mg} / \mathrm{L}$ at the West Little Owyhee River during the June base flow (when water in this tributary was not flowing to the Owyhee River and probably consisted entirely of ground-water seepage), concentrations of dissolved oxygen ranged from 7.7 to $12.2 \mathrm{mg} / \mathrm{L}$ (table 3 ).
These concentrations exceeded the minimum single-observation criterion $(5.5 \mathrm{mg} / \mathrm{L})$ recommended for warmwater aquatic life (Oregon Department of Environmental Quality, 2002). Although few concentrations equaled or exceeded $11 \mathrm{mg} / \mathrm{L}$, the minimum single-observation criterion recommended for salmonid spawning (Oregon Department of Environmental Quality, 2002), most were within 95 to 133 percent of saturated conditions.

Predawn oxygen concentrations at two sites near Rome may have been low, but it is not known whether criteria were violated. Significant oxygen supersaturation at site OR4 (161 percent during the June base flow) suggests that this particularly slow-moving reach might experience excess phytoplankton production. Respiration by these communities can cause significant oxygen depletion during nighttime periods when photosynthesis is not occurring. In addition, the benthic invertebrate community at this site had the highest total number of organisms and the highest numbers of filter-feeding caddisflies (see section, "Benthic Invertebrate Communities"), which suggests that organic loading and subsequent decomposition also may contribute to oxygen depletion at this site. Also near Rome, the extensive filamentous periphyton community observed at site JC1 had significantly higher biomass and chlorophyll- $a$ content than all other communities measured, and this condition also might result in nighttime depletions of dissolved oxygen. An instrumentation breakdown prevented measuring dissolved oxygen at this site during the June base flow. However, the large numbers of tolerant invertebrate taxa at this site (including oligochaetes, which are particularly tolerant of low dissolved oxygen) and lowest numbers of sensitive Ephemeroptera, Plecoptera, and Trichoptera (EPT) taxa suggest that low dissolved oxygen concentrations could be common in Jordan Creek.

Solubility of oxygen may be reduced further at elevated water temperatures that are common in July and August. At the maximum single-observation and 7-day mean temperatures $\left(30.9^{\circ}\right.$ and $27.7^{\circ} \mathrm{C}$ ) (fig. 4) and the lowest barometric pressure (647 mm mercury) measured during this study, saturated dissolved oxygen concentrations are 6.3 and $6.6 \mathrm{mg} / \mathrm{L}$. These calculated concentrations still exceed the minimum concentrations recommended for warmwater aquatic life.

\section{pH}

The amount and behavior of many chemicals in water and the health of many aquatic biological communities are affected by $\mathrm{pH}$. The $\mathrm{pH}$ of uncontaminated river water generally ranges from 6.5 to 8.5 (Hem, 1985). Photosynthesis by aquatic plants generally increases $\mathrm{pH}$ during the day, and respiration by plants and animals generally decreases $\mathrm{pH}$ at night.

The $\mathrm{pH}$ at all sites ranged from 7.4 to 9.1 (table 3). Only one $\mathrm{pH}$ measurement (site JC1 during June base flow) exceeded 9, the maximum recommended for Oregon water (Oregon Department of Environmental Quality, 2002). Measurements at the other sites during base flow (ranging from 7.7 to 8.9 ) generally were the highest recorded for each site, and 
some were close to the maximum criteria. Consumption of carbon dioxide by the summer photosynthetic activity of phytoplankton and periphyton, combined with the naturally basic high-bicarbonate water in the basin, is the likely cause of these elevated $\mathrm{pH}$ values. At site $\mathrm{JC} 1$, the biomass $\left(79 \mathrm{~g} / \mathrm{m}^{2}\right)$ and chlorophyll- $a$ content $\left(86 \mathrm{mg} / \mathrm{m}^{2}\right)$ of the extensive filamentous periphyton community were the highest measured in the study area. At site OR4, a pH of 8.9 and supersaturation of dissolved oxygen suggest that vigorous photosynthetic activity by phytoplankton sometimes might induce $\mathrm{pH}$ values to exceed criteria. It is likely that $\mathrm{pH}$ at all these sites decreased significantly at nighttime when reduced photosynthetic activity, combined with respiration, increased carbon dioxide in the streams.

\section{Major lons}

Major ions in water are those composing most of the dissolved solids in water and normally include calcium, magnesium, sodium, potassium, chloride, fluoride, bicarbonate, and sulfate. They dissolve in water having contact with naturally occurring minerals in the basin, and the proportions of their concentrations in water (water type) often reflect the geology of the basin. Some land uses also contribute selected major ions and, thus, affect the water type in a basin.

Major ions were compared using the patterns (Stiff, 1951) shown in figure 6 The relative sizes of these patterns distinguish differences in dissolved solids concentrations, and the shapes distinguish variations in major ion compositions. At each site except North Fork, concentrations of dissolved solids were about 2 to 6 times higher during base flow (ranging from 94 to $222 \mathrm{mg} / \mathrm{L}$ ) than during spring runoff (ranging from 46 to $133 \mathrm{mg} / \mathrm{L}$ ). In contrast, dissolved solids concentrations were similar on the North Fork Owyhee River during base flow and spring runoff (ranging from 52 to $70 \mathrm{mg} / \mathrm{L}$ ).

Major ion compositions ranged from calcium-bicarbonate-dominated to sodium-bicarbonate-dominated water types (fig. 6). Water types at tributary sites WLO1 and NF1 were fairly consistent during all sampling events. At Owyhee River sites and Jordan Creek, water types differed during base and runoff flows. Water in the Owyhee River generally became increasingly dominated by sodium in a downstream direction.

The concentrations of dissolved solids and extent of sodium domination probably reflect the predominant sources of water composing streamflow. Water derived from the upper elevations in the basin (such as the North Fork Owyhee River and the West Little Owyhee River) tends to be low in dissolved solids and dominated by calcium, sodium, and bicarbonate. These characteristics probably reflect contact with feldspars in the granite composing the upland areas. Water derived from lower elevations likely includes ground-water seepage from arid soils, rhyolite, basalt, and evaporite minerals that contribute high concentrations of sodium bicarbonate. Mariner and others (1994) also reported that geothermal springs near the Owyhee River contribute sodium-bicarbonate-dominated water. As a result, sodium-dominated water measured at most Owyhee River sites during base flow sug- gests that most streamflow was contributed by ground-water seepage in the low-elevation parts of the basin. In contrast, the calcium- and sodium-codominated water measured at downstream Owyhee River sites during spring runoff suggests that a large proportion of streamflow was derived from high-elevation snowmelt.

All sodium concentrations measured in the Owyhee River and tributaries were too low to present undesirable cation exchange effects for irrigation use. However, dissolved solids concentrations during base flow were high enough to present a medium salinity hazard for irrigation (Hem, 1985, p. 217-218).

Fluoride concentrations were generally less than $1 \mathrm{mg} / \mathrm{L}$ in tributaries and during spring runoff at Owyhee River sites (table 3). However, concentrations ranged from 1.7 to 2.4 $\mathrm{mg} / \mathrm{L}$ during base flow at Owyhee River sites. Both the volcanic rocks in the basin and geothermal springs near and in the river may be sources of fluoride (Hem, 1985, p. 21) that are least diluted during base-flow conditions. Mariner and others (1994) reported concentrations of fluoride in the geothermal springs near the river as high as $29 \mathrm{mg} / \mathrm{L}$, more than 16 times the concentration measured during base flow at site OR7, the farthest upstream site in the study area. Such high concentrations might make fluoride a good surrogate ion to use to help estimate the volume of hot water that geothermal springs contribute to the Owyhee River.

\section{Nutrients}

Nitrogen and phosphorus are nutrients that are essential to aquatic plant growth, and high nutrient concentrations can cause undesirably high amounts of instream plant growth. In instances when one nutrient (such as nitrogen) is present in large concentrations but the other (phosphorus) is in short supply, plant communities can develop only as long as the shortsupply nutrient (called the limiting nutrient) is available. Common sources of nitrogen and phosphorus to streams include naturally occurring geologic and organic materials and contamination by fertilizers, sewage, and animal wastes. In addition, nitrogen can be "fixed" directly from the atmosphere by some organisms such as blue-green algae. Igneous rocks commonly contain relatively high concentrations of phosphorus compared with concentrations in other rocks (Hem, 1985, p. 3).

Total nitrogen $(\mathrm{N})$ concentrations (combined concentrations of total ammonia plus organic $\mathrm{N}$ and dissolved nitrite plus nitrate $\mathrm{N}$, table 3) ranged from 0.14 to $2.6 \mathrm{mg} / \mathrm{L}$; most concentrations were less than the $1.9 \mathrm{mg} / \mathrm{L}$ national median for 179 basins sampled as part of the NAWQA Program from 1991 to 2001 (accessed April 2003 at http://water.usgs.gov/nawqa/ nutrients/datasets/nutconc2000/\#SW). Concentrations were highest (exceeding $0.9 \mathrm{mg} / \mathrm{L}$ ) in the lower reaches of the study area at sites OR4, JC1, OR3, and OR2. All ammonia concentrations were at or below the laboratory reporting limit of 0.05 $\mathrm{mg} / \mathrm{L}$ as N.

Nitrogen concentrations were generally lowest and uniform at all sites during June base flow (table 3). All concentra- 
14 Reconnaissance of Chemical and Biological Quality, Owyhee River, Oregon State Line to the Owyhee Reservoir, Oregon, 2001-02

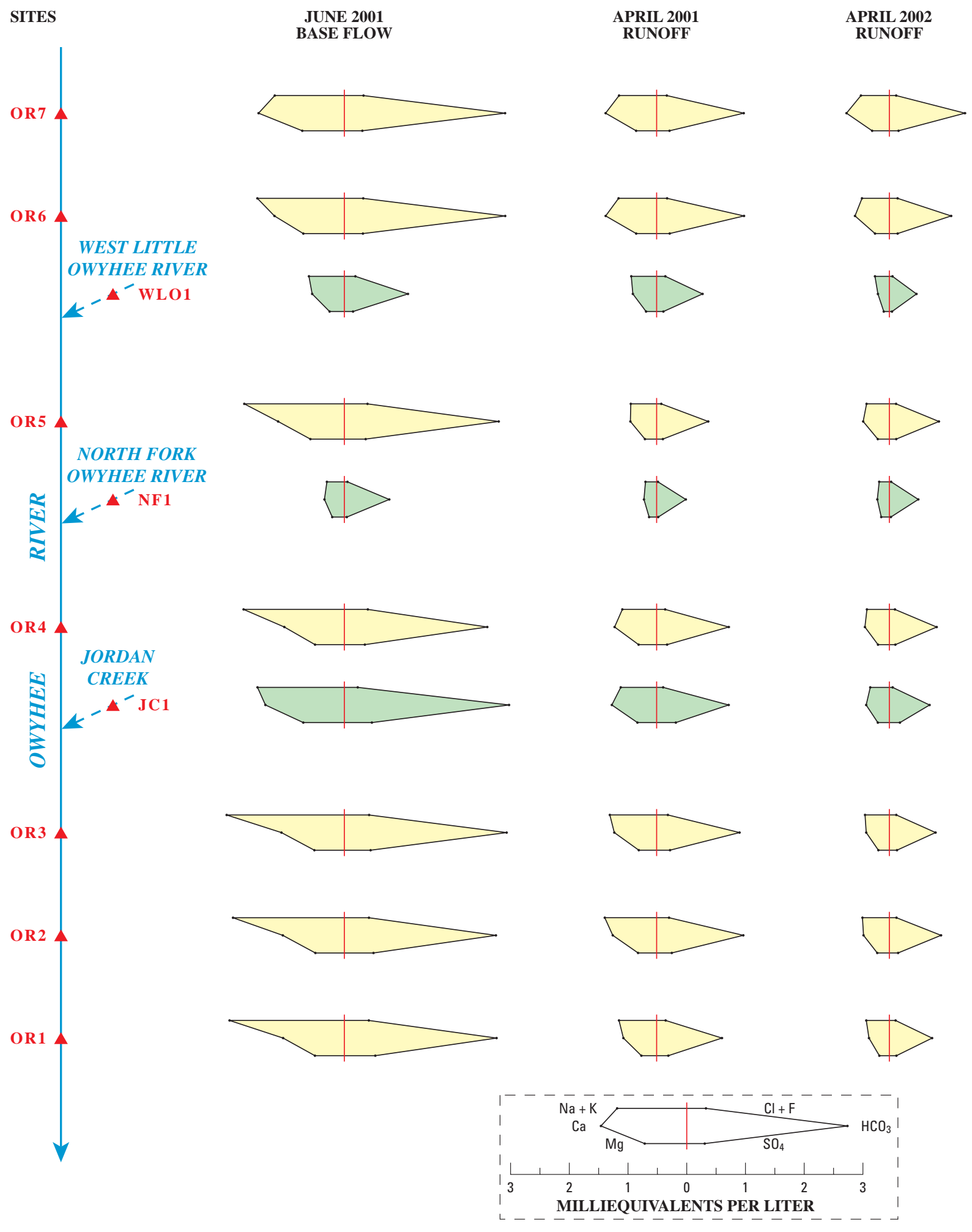

Figure 6. Stiff patterns representing major ions in the Owyhee River and selected tributaries, Oregon, 2001 and 2002. (Site locations shown in figure 2 ) 
tions of total $\mathrm{N}$ were less than $0.7 \mathrm{mg} / \mathrm{L}$, and inorganic nitrogen concentrations (combined concentrations of ammonia as $\mathrm{N}$ and nitrite plus nitrate as $\mathrm{N}$ ) were all less than or only slightly greater than the $0.3 \mathrm{mg} / \mathrm{L}$ concentration considered essential to stimulate algal growth when adequate phosphorus is present (Mackenthun, 1969). Conditions during the 2001 spring runoff were nearly the same as those during base flow (fig. 7), possibly as a result of the small amount of precipitation that the basin received during the preceding winter.

During the 2002 spring runoff, concentrations of organic and particulate nitrogen were high at all sites, and concentrations were highest near and downstream from Rome (fig. 7). Concentrations peaked at site OR4 and gradually decreased downstream at sites OR3, OR2, and OR1. A comparison between dissolved and total ammonia plus organic N concentrations (table 3 ) indicates that most of the high downstream concentrations were associated with organic particles, possibly dislodged periphyton and materials flushed from adjacent lands. The nitrogen concentration at site OR4 on April 12 was more than 3 times higher than on April 3, when discharge exceeded the April 12 discharge (fig. 7). This suggests that these elevated concentrations might be of short duration during runoff periods.

Total nitrogen concentrations were higher at Jordan Creek than at other tributary sites during all sampling events (fig. 7 and table 3). This basin has the greatest amounts of cultivated and developed land cover in the study area (table 2). Although the large populations of periphyton (see section, "Periphyton Communities") at the site demonstrate that nutrients are enriched at the site, measurements of inorganic nitrogen during both spring runoff events only slightly exceeded the $0.3 \mathrm{mg} / \mathrm{L}$ concentration considered necessary for stimulating algal growth. This suggests that the periphyton community might already have incorporated nitrogen from the stream water and also might obtain nitrogen from ground-water seepage or stream-bottom materials. Instantaneous loads of nitrogen transported by Jordan Creek were small (about 7 to 15 percent) compared with those transported by the Owyhee River just upstream from the Jordan Creek confluence (site OR4) (fig. 7).

Total phosphorus concentrations ranged from $<0.06$ to $0.23 \mathrm{mg} / \mathrm{L}$ (table 3). Most concentrations were less than the $0.18 \mathrm{mg} / \mathrm{L}$ national median for 179 basins sampled as part of the NAWQA Program from 1991 to 2001 (accessed April 2003 at http://water.usgs.gov/nawqa/nutrients/datasets/ nutconc2000/\#SW). The highest concentrations equaled or exceeded $0.1 \mathrm{mg} / \mathrm{L}$ and were measured in the lower reaches of the study area at sites OR5, OR4, JC1, OR3, OR2, and OR1.

During base flow, total phosphorus and orthophosphate concentrations were typically below laboratory reporting limits, and all total phosphorus concentrations were less than the $0.1 \mathrm{mg} / \mathrm{L}$ maximum concentration recommended for preventing nuisance biological growth in flowing water (Mackenthun, 1969).

During spring runoff, orthophosphate concentrations generally remained near laboratory reporting limits, but con- centrations of organic plus particulate phosphorus were higher than those during base flow (fig. 8). The spatial concentration pattern for phosphorus mimicked that for suspended sediment (fig. 5), which suggests that much of the phosphorus was transported on inorganic particles contributed by land adjacent to the river and tributaries. Total phosphorus concentrations in the Owyhee River equaled or exceeded $0.1 \mathrm{mg} / \mathrm{L}$ at sites OR4, OR3, OR2, and OR1 during the 2002 spring runoff and only at site OR5 during the smaller-than-normal 2001 runoff. The concentration at site OR4 on April 12, 2002, was less than half that on April 3 when discharge was higher. This suggests that such elevated concentrations might be of short duration.

The only tributary where total phosphorus concentrations exceeded $0.1 \mathrm{mg} / \mathrm{L}$ during both spring runoff events was Jordan Creek (fig. 8). Large populations of periphyton at the site support this measurement of enriched nutrient concentrations. Despite enriched phosphorus concentrations, instantaneous loads of phosphorus transported by Jordan Creek were about 25 to 34 percent of those transported by the Owyhee River just upstream from the Jordan Creek confluence (site OR4) (fig. 8). Similar to suspended sediment loads, the high phosphorus load at site OR3 in April 2002 (about 10 times that at Jordan Creek) suggests that cultivated and developed lands downstream from the Jordan Creek confluence and (or) input from Crooked Creek also may contribute significant amounts of phosphorus to the Owyhee River.

Nutrient limitation appears to vary within the study area. For samples containing either nitrogen or phosphorus concentrations equal to or exceeding the algal production criteria of 0.3 and $0.1 \mathrm{mg} / \mathrm{L}$, respectively, mass ratios of dissolved inorganic nitrogen to dissolved orthophosphate as $\mathrm{P}(\mathrm{N}: \mathrm{P})$ were calculated to give some insight into nutrients that may limit primary productivity (table 5). Ryding and Rast (1989) indicated that, on the basis of a preferential uptake ratio by algae, $\mathrm{N}$ :P exceeding 7.2 may indicate phosphorus limitation, and $\mathrm{N}: \mathrm{P}$ less than 7.2 may indicate nitrogen limitation. Ratios for water in the upper study area (upstream from Rome) and just upstream from Lake Owyhee (site OR1) were low, which sug-

Table 5. Mass ratios of dissolved inorganic nitrogen to orthophosphorus as phosphorus for sites on the Owyhee River and selected tributaries, Oregon, 2001 and 2002

[Site locations shown in figure 2 No., number; ratios shown for sites where concentrations of inorganic nitrogen or total phosphorus exceeded 0.3 or 0.1 milligrams per liter, respectively]

\begin{tabular}{l|c|c|c}
\hline \multirow{2}{*}{\multicolumn{1}{c|}{ Site No. }} & June & April & $\mathbf{2 0 0 2}$ \\
\cline { 2 - 4 } OR5 & & 1.5 & April \\
\hline OR4 & & & 3.3 \\
\hline JC1 & & 10.3 & 11.3 \\
\hline OR3 & & & 11 \\
\hline OR2 & 16 & & 10.5 \\
\hline OR1 & & & 4.7 \\
\hline
\end{tabular}



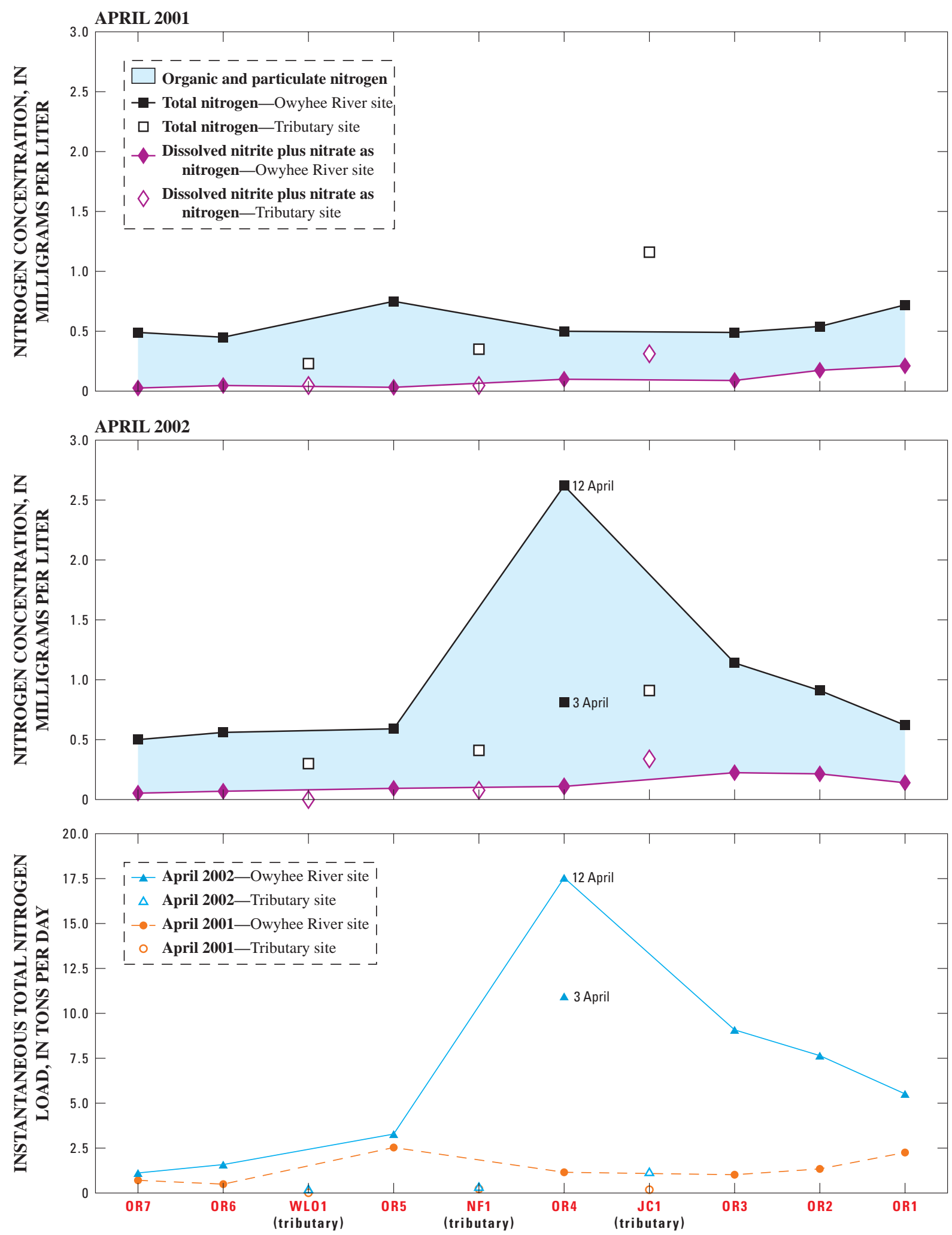

SITES

Figure 7. Nitrogen concentrations and instantaneous loads in the Owyhee River and selected tributaries, Oregon, during spring runoff in 2001 and 2002. (Site locations shown in figure 2 ) 

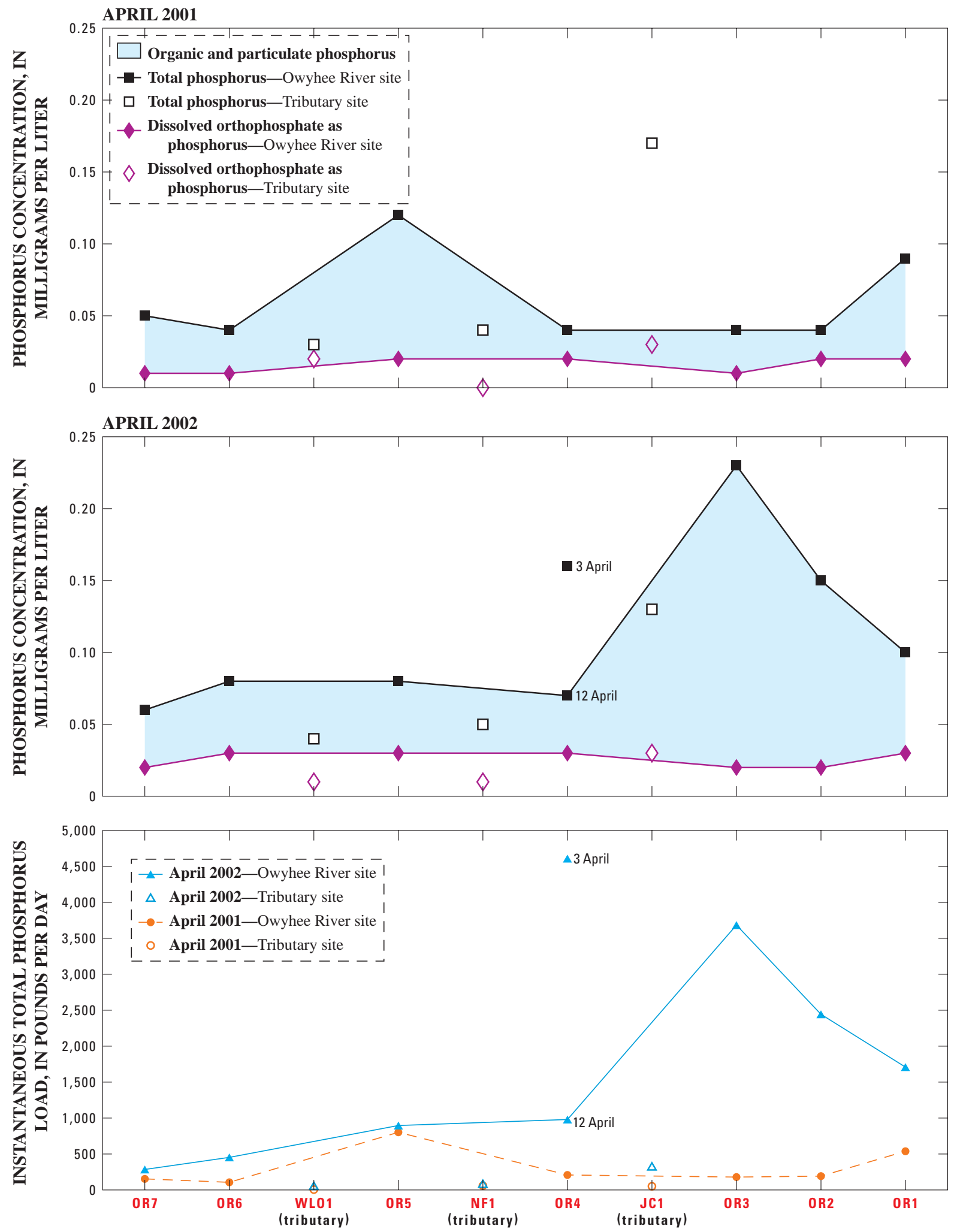

SITES

Figure 8. Phosphorus concentrations and instantaneous loads in the Owyhee River and selected tributaries, Oregon, during spring runoff in 2001 and 2002. (Site locations shown in figure 2 ) 
Table 6. Concentrations and loads of total nitrogen and phosphorus at site 0R1, 2001 and 2002, in relation to estimated average discharge to Lake Owyhee, Oregon, 1996-98

[Site locations shown in figure 2; summer, June base flow; spring, April runoff; N, nitrogen; P, phosphorus; mg/L, milligrams per liter; lb/d, pounds per day; $<$, less than]

\begin{tabular}{|c|c|c|c|c|c|c|c|c|}
\hline & $\begin{array}{c}\text { Summer } \\
\text { total N } \\
\text { concen- } \\
\text { tration } \\
\text { (mg/L) }\end{array}$ & $\begin{array}{c}\text { Spring } \\
\text { total N } \\
\text { concentration } \\
(\mathrm{mg} / \mathrm{L})\end{array}$ & $\begin{array}{l}\text { Summer } \\
\text { total N } \\
\text { load } \\
\text { (lb/d) }\end{array}$ & $\begin{array}{l}\text { Spring } \\
\text { total N load } \\
\text { (lb/d) }\end{array}$ & $\begin{array}{c}\text { Summer } \\
\text { total P } \\
\text { concen- } \\
\text { tration } \\
(\mathrm{mg} / \mathrm{L})\end{array}$ & $\begin{array}{c}\text { Spring } \\
\text { total P } \\
\text { concentration } \\
\text { (mg/L) }\end{array}$ & $\begin{array}{c}\text { Summer } \\
\text { total P } \\
\text { load } \\
\text { (lb/d) }\end{array}$ & $\begin{array}{l}\text { Spring } \\
\text { total P } \\
\text { load } \\
(\mathrm{lb} / \mathrm{d})\end{array}$ \\
\hline $\begin{array}{l}\text { Average discharge to } \\
\text { Lake Owyhee } \\
\text { (Craft and others, 2000) .... }\end{array}$ & 0.6 & 0.445 & 417 & 11,995 & 0.0325 & 0.095 & 30 & 1,900 \\
\hline Site OR1.. & .51 & $\begin{array}{l}.72(2001) \\
.62(2002)\end{array}$ & 776 & $\begin{array}{r}4,508(2001) \\
11,038(2002)\end{array}$ & $<.06$ & $\begin{array}{l}.086(2001) \\
.096(2002)\end{array}$ & $<90$ & $\begin{array}{r}538(2001) \\
1,709(2002)\end{array}$ \\
\hline
\end{tabular}

gests nitrogen limitation (table 5). Ratios for water at sites on the Owyhee River and Jordan Creek between these areas were high, which suggests phosphorus limitation. Nutrient limitation can change over time and in response to changing hydrologic conditions. Also, the reservoir of nutrients contained in periphytic communities and stream-bottom materials is not considered in these ratios. As a result, a comprehensive assessment of nutrient limitation would require significantly more sampling than this reconnaissance provides.

Concentrations and loads of nitrogen and phosphorus discharged to Lake Owyhee by the Owyhee River were estimated by Craft and others (2000) by using data collected near Rome, Oregon, during 1996-98. A comparison of these data with the instantaneous measurements made closer to the lake for this reconnaissance at site OR1 is shown in table 6.

Concentrations of nitrogen and phosphorus in the summer and phosphorus concentrations in the spring at site OR1 compared fairly well (within 15 percent) with the concentrations estimated by Craft and others (2000). However, spring nitrogen concentrations for this reconnaissance were about 39 to 62 percent higher than those estimated. Additional sources of nitrogen between Rome and site OR1, differences in sampling techniques (grab samples used by Craft and others versus flow-integrated samples used for this reconnaissance), and streamflow volumes exceeding those used by Craft and others probably account for some of the concentration differences.

Loads of nitrogen in summer during this reconnaissance were about 86 percent higher than the estimated loads. Higher stream discharges at site OR1, compared with those used by Craft and others, probably account for most of these load differences. The April 2002 loads of both nitrogen and phosphorus were within about 10 percent of the estimated loads. However, April 2001 nitrogen and phosphorus loads were about 62 and 72 percent, respectively, lower than the estimated loads. These low loads almost certainly were caused by the low spring discharge in the Owyhee River in 2001.

\section{Trace Elements}

Trace elements include many metallic and some nonmetallic elements that typically are present in water at concentrations far below $1 \mathrm{mg} / \mathrm{L}$. Some of these elements can be toxic to aquatic life, whereas others are essential micronutrients that are beneficial in small concentrations but toxic in larger concentrations. Because trace elements are not degradable, their concentrations can be magnified in the upper trophic levels of food chains, such as fish. Some geologic formations are naturally rich sources of trace elements to streams, and many land uses such as mining, industry, agriculture, and urban areas discharge trace elements to streams.

Transport of trace elements in streams is often sporadic and difficult to capture without collecting large numbers of samples. Because many trace elements, especially metals, have low solubilities and are preferentially incorporated into sediments, samples of stream-bottom materials often contain

\section{EXPLANATION}

for figure 9

Maximum value
75th percentile value
Median value
25th percentile value
Minimum value

Data from Owyhee River and tributaries

Data from Rinella and others, 1994

Bulk sediment Threshold Effects Level (TEL) for aquatic biota according to Washington State Department of Ecology (Batts and Cubbage, 1995)

Bulk sediment Probable Effects Level (PEL) for aquatic biota according to Washington State Department of Ecology (Batts and Cubbage, 1995)

$I_{R L}^{R L}$ No analyte detected at reporting limits (RL) shown

$\downarrow$

- Analyte detected when all other measurements were below detection limits 


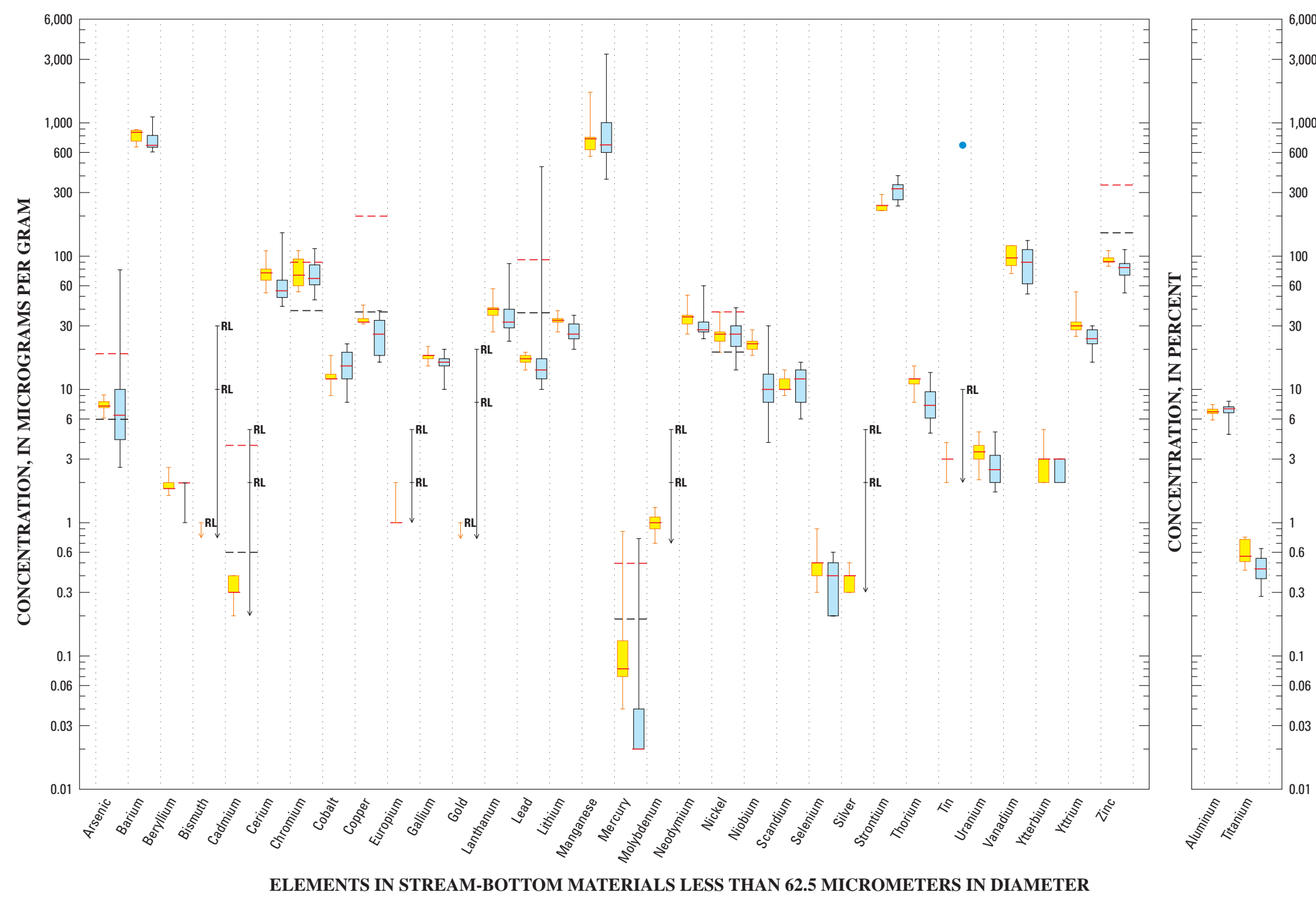

Figure 9. Trace element concentrations in stream-bottom materials from the Owyhee River and selected tributaries, Oregon, in relation to concentrations in regional streams sampled by Rinella and others (1994). 
time-integrated accumulations of metals that are better indicators of impacted areas than are water samples.

During this reconnaissance, concentrations of 39 trace elements on stream-bottom materials were analyzed to help determine zones of the basin that were significant sources of trace elements. Because of their large surface area, fine sediments tend to accumulate higher concentrations of trace metals than do coarse sediments (Horowitz, 1991, p. 20-21). As a result, only stream-bottom materials less than $62.5 \mu \mathrm{m}$ in diameter were collected and analyzed for this study, which allowed data from the different sites to be compared. In addition, water samples were analyzed for two nonmetallic trace elements - arsenic and selenium - that have stream health implications and that frequently are dissolved in water of the Western United States.

As part of an investigation of stream quality associated with the Owyhee and Vale irrigation projects in southeastern Oregon and southwestern Idaho, Rinella and others (1994) analyzed most of the same elements in stream-bottom materials as were analyzed for this study. Rinella and others also used the same sampling and analytical techniques as were used in this study. In general, concentration ranges of most elements collected for this reconnaissance were similar to those reported for the irrigation studies (fig. 9). However, for nearly half of the trace elements analyzed for this reconnaissance (arsenic, barium, cerium, copper, gallium, lanthanum, lead, lithium, mercury, neodymium, niobium, thorium, titanium, uranium, yttrium, and zinc), more than 75 percent of the concentrations exceeded the median concentrations reported for the irrigation studies. This may be because samples for this reconnaissance were collected in areas of the watershed that were closer to geologic formations naturally enriched with trace elements, as evidenced by the number of mines that have been developed in the upper basin.

Probability plots of data from all sites were used to determine samples that were enriched with trace elements relative to samples from other sites in the basin (Velz, 1970, p. 522-542; Rickert and others, 1977, p. F13-F18; Hardy, 1984, p. 17-20). Concentrations that plotted on a straight line were considered "background" concentrations. Concentrations that plotted significantly above the background line were considered enriched concentrations that belonged to a different statistical population. A plot for aluminum as an example of an ubiquitous metal that was not enriched at any particular site is shown in figure 10. In contrast, a plot for mercury as an example of a metal that was enriched at two sites is shown in figure 11.

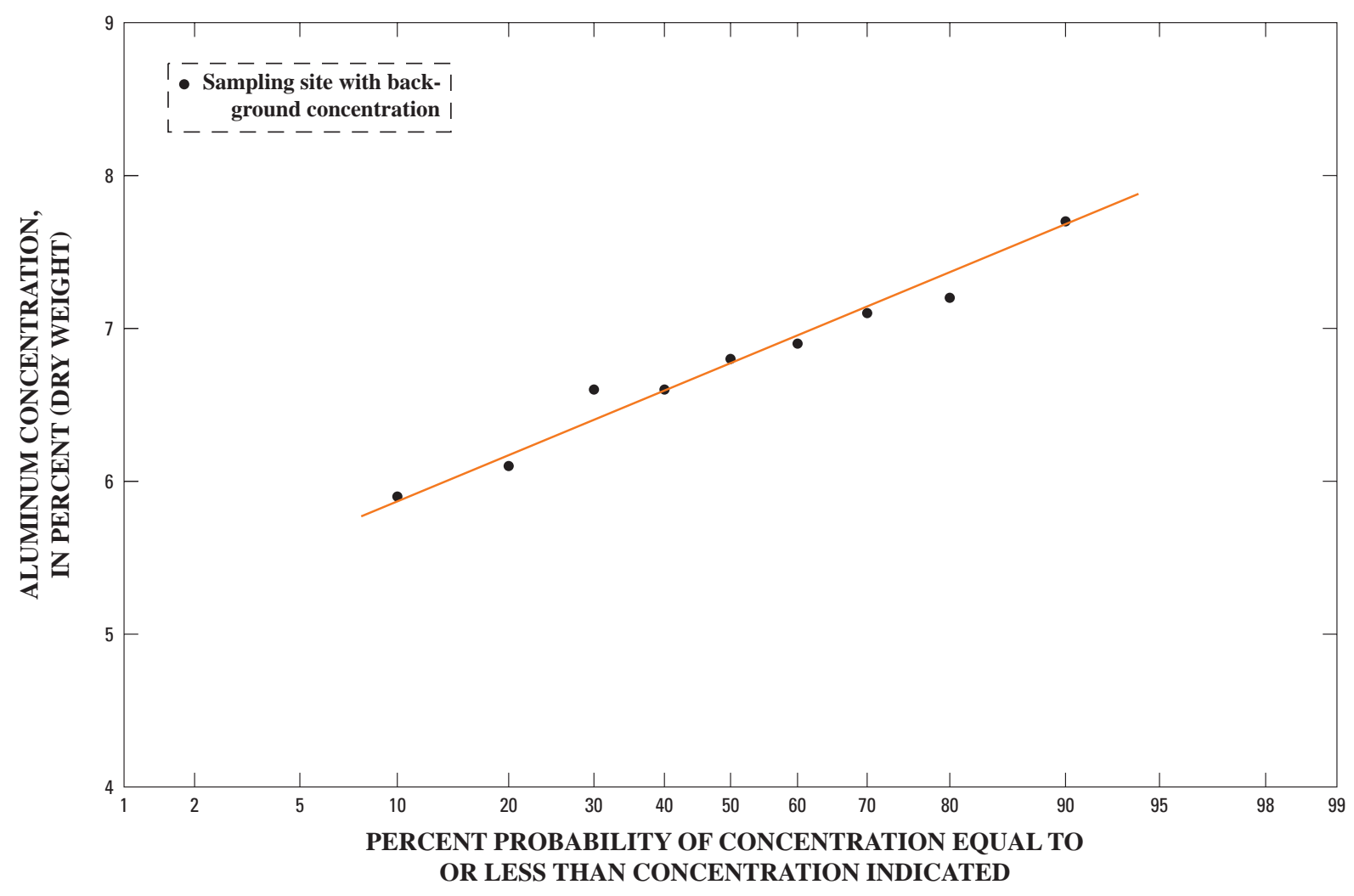

Figure 10. Aluminum concentrations in stream-bottom materials less than 62.5 micrometers in diameter from the 0 wyhee River and selected tributaries, Oregon. 
Enriched trace element concentrations are summarized in table 7. Only two elements, manganese and mercury, were enriched at site JC1, where a high density of upstream mines (table 1) suggests high potential for trace element mobilization. It is not known whether the wetlands and small reservoirs upstream from this site act to enhance concentrations of these trace elements or to deplete others. Nine trace elements (beryllium, cerium, copper, lanthanum, neodymium, nickel, titanium, yttrium, and zinc) were most highly enriched at site NF1, where no mines are located upstream. This result suggests that natural sources (such as local rocks and geothermal springs) might be more significant sources of some trace elements than mining activities are. Four of these trace elements (copper, mercury, nickel, and titanium) also were enriched farther downstream at sites OR1 and (or) OR4. It is not known whether the enrichments at these sites were due to additional sources of these metals or simply to the sites' locations in lowgradient zones of the river that tend to accumulate fine sediments.

The lack of selenium enrichment in sediments supports the water-chemistry data showing low selenium concentrations (all were below reporting limits) in stream water throughout the watershed. Although arsenic was not enriched in sediments at any site, dissolved concentrations were common and were highest during base flow at sites OR1, OR2, and OR3. These elevated concentrations (10 to $11 \mu \mathrm{g} / \mathrm{L}$ ) may be caused by geothermal springs (Hem, 1985, p. 184-185) that discharge to the lower reaches of the study area, but the concentrations were well below maximum brief- and continuousexposure concentrations ( 340 and $150 \mu \mathrm{g} / \mathrm{L}$, respectively) recommended for the protection of aquatic communities (U.S. Environmental Protection Agency, 2002, p. 12, Federal Register source 65FR31682).

High concentrations of some trace elements on streambottom materials can be harmful to aquatic biota living on and in them. Criteria for protection of biota currently do not exist in the United States, but the Washington State Department of Ecology (Batts and Cubbage, 1995) has established guidelines that are based on proposed criteria. These guidelines are based on partial digestions of bulk sediment samples. Partial digestions primarily include trace elements only in particle coatings; complete digestions include trace elements in both the particle coatings and the matrices. Because the analyses for this reconnaissance were complete digestions of fine particles, which tend to have a higher affinity for sorbing trace elements,

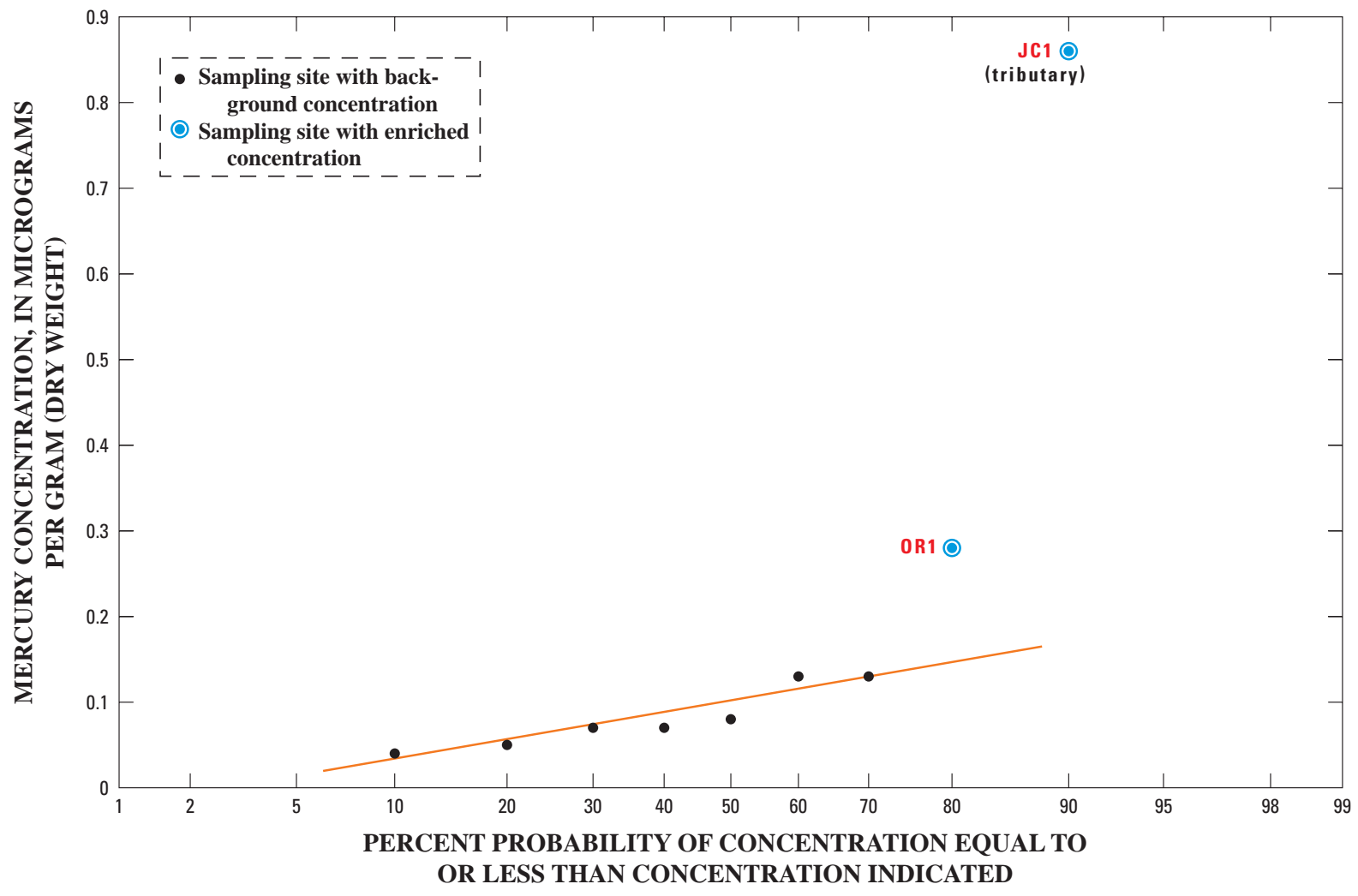

Figure 11. Mercury concentrations in stream-bottom materials less than 62.5 micrometers in diameter from the 0 wyhee River and selected tributaries, Oregon. 
Table 7. Stream-bottom materials less than 62.5 micrometers in diameter enriched in trace element concentrations, Owyhee River and selected tributaries, Oregon

[Site locations shown in figure 2; No., number; blank values indicate measurements of background concentrations; $\mu \mathrm{g} / \mathrm{g}$, micrograms per gram; \%, percent]

\begin{tabular}{|c|c|c|c|c|c|}
\hline \multirow[b]{2}{*}{ Trace element concentrations } & \multicolumn{4}{|c|}{ Site No. } & \multirow{2}{*}{$\begin{array}{l}\text { Background } \\
\text { range }\end{array}$} \\
\hline & NF1 & OR4 & JC1 & OR1 & \\
\hline Barium $(\mu \mathrm{g} / \mathrm{g}) \ldots \ldots \ldots \ldots \ldots$ & 2.6 & & & & $1.6-2.1$ \\
\hline Cerium $(\mu \mathrm{g} / \mathrm{g}) \ldots \ldots \ldots \ldots$ & 110 & & & & $53-81$ \\
\hline Copper $(\mu \mathrm{g} / \mathrm{g}) \ldots \ldots \ldots \ldots \ldots$ & 43 & & & 38 & $31-34$ \\
\hline Lanthanum $(\mu \mathrm{g} / \mathrm{g}) \ldots \ldots \ldots \ldots$ & 57 & & & & $27-44$ \\
\hline Manganese $(\mu \mathrm{g} / \mathrm{g})$. & & & 1,700 & & $560-840$ \\
\hline Mercury $(\mu \mathrm{g} / \mathrm{g}) \ldots \ldots \ldots \ldots \ldots$ & & & .86 & .28 & $0.04-0.13$ \\
\hline Neodymium $(\mu \mathrm{g} / \mathrm{g}) \ldots \ldots \ldots \ldots$ & 51 & & & & $26-38$ \\
\hline Nickel $(\mu \mathrm{g} / \mathrm{g}) \ldots$ & 38 & & & 34 & $19-27$ \\
\hline Titanium $(\%) \ldots \ldots \ldots \ldots \ldots$ & .78 & 0.75 & & .75 & $0.44-0.57$ \\
\hline Yttrium $(\mu \mathrm{g} / \mathrm{g}) \ldots \ldots \ldots \ldots \ldots$ & 54 & & & & $25-33$ \\
\hline $\operatorname{Zinc}(\mu \mathrm{g} / \mathrm{g}) \ldots \ldots \ldots \ldots \ldots \ldots$ & 110 & & & & $84-99$ \\
\hline
\end{tabular}

the analyses would be expected to yield higher trace element concentrations.

Concentrations of arsenic, chromium, copper, mercury, and nickel exceeded the threshold-effect guidelines and the probable-effect guidelines at several sites in the study area (fig. 9). Considering that the maximum concentrations of arsenic and copper for this reconnaissance were less than 1.6 times the threshold-effect guidelines, it is likely that concentrations in bulk sediment would not threaten aquatic communities. However, because the maximum concentrations of chromium (at sites NF1, OR4, and OR1), nickel (at site NF1), and mercury (at site JC1) were 2.1 to 4.9 times the thresholdeffect guidelines and also exceeded probable-effect guidelines, it is possible that concentrations in bulk sediments might be high enough to compromise selected populations of biota. Although chromium exceeded probable-effect guidelines at three sites, concentrations at all sites were high enough that it was not considered enriched at any particular site.

\section{Bacteria}

Escherichia coli bacteria (E. coli) inhabit the digestive tract of warmblooded animals and, therefore, are indicators of fecal wastes in water. Water receiving fecal contamination from warmblooded animals is considered at risk for the presence of pathenogenic organisms that can infect humans ingesting or recreating in that water.

Populations of E. coli ranged from $<1$ to 370 (MPN/100 mL) (table 3), all less than the maximum 406 organisms $/ 100 \mathrm{~mL}$ recommended for a single instream measurement before additional followup investigation is required (Oregon Department of Environmental Quality, 2002). During the spring runoff and base flow in 2001, no populations exceeded $50 \mathrm{MPN} / 100 \mathrm{~mL}$ at any site. Populations were highest (32 and $50 \mathrm{MPN} / 100 \mathrm{~mL}$ ) at Jordan Creek (site JC1); all other populations were less than 15 MPN/100 mL. The high populations at Jordan Creek during base flow suggest a source of fecal material in the stream that tends to be diluted at high flows.

During the 2002 spring runoff, populations were highest (140 and $370 \mathrm{MPN} / 100 \mathrm{~mL}$ ) at sites OR3 and OR2. Populations at all other sites were less than or equal to 24 MPN/100 $\mathrm{mL}$. The high bacterial populations during the 2002 spring runoff suggest that flushing of fecal material from adjacent lands in and downstream from the Rome area and Crooked Creek may be the primary source of bacteria in the study area. 


\section{Benthic Invertebrate Communities}

Various metrics described by Hayslip (1993) and Barbour and others (1999) were calculated to describe the benthic invertebrate assemblages at each site (table 8). A metric is an enumeration representing an assemblage characteristic or combination of characteristics that change in a predictable way with increased human influence (Karr and others, 1986). Coldwater taxa were identified using the Idaho Department of Environmental Quality empirically derived list (Grafe and others, 2002). There is less than a 10-percent chance that these taxa will be present where temperatures exceed $19^{\circ} \mathrm{C}$. The modified Hilsenhoff Biotic Index (HBI, includes all benthic invertebrates) was calculated following the methods of Barbour and others (1999). Tolerance values ranging from 0 to 10 are assigned to each taxa on the basis of tolerances to sediment and organic waste for Northwestern streams (G. Lester, EcoAnalysts, Moscow, Idaho, oral commun., 2002). A value of 0 indicates that a taxon occurs in very high quality water, whereas a value of 10 indicates a taxon known to occur in severely polluted streams. Final HBI indices also range from 0 to 10 ; a rating of 0 reflects excellent water quality with no organic or sediment pollution, and 10 indicates severe organic and sediment pollution (Lydy and others, 2000). For wadeable streams in the Northwest, an HBI score of $>5.0$ indicates impaired water quality (B. Wisseman, Aquatic Biological Associates, written commun., 2002).

Samples of benthic invertebrate communities were collected only at 9 of the 10 sampling sites. Samples were not collected at site WLO1 because this tributary was not flowing at the time of sampling. At least 120 taxa were identified in riffle samples collected from the 9 sampling sites (table 9 , back of report). Total abundance (table 8) ranged from 3,616 to 16,864 individuals $/ \mathrm{m}^{2}$ at the North Fork Owyhee River (site NF1) and Owyhee River near Rome (site OR4), respectively. The associated microhabitat characteristics for each site are summarized in table $\mathbf{1 0}$.

Aquatic insects composed most of the benthic invertebrate assemblages sampled. Taxa collected at all sites were Baetis tricaudatus, Tricorythodes sp., Microcylloepus sp., Psephenus sp., Hydropsyche sp., Simulium sp., Polypedilum sp., Turbellaria, and Acari. Colonies of the freshwater mussels Gonidea angulata were collected only at the Owyhee River at State Line (site OR7).

There was no apparent downstream decline in the number of benthic invertebrate taxa at Owyhee River sites. Total

Table 8. Benthic invertebrate metric results for the Owyhee River and selected tributaries, Oregon, June through July 2001 [Site locations shown in figure 2; No., number; EPT, Ephemeroptera, Plecoptera, and Trichoptera taxa; no. $/ \mathrm{m}^{2}$, number of individuals per square meter]

\begin{tabular}{|c|c|c|c|c|c|c|c|c|c|}
\hline \multirow[b]{2}{*}{ Metric } & \multicolumn{9}{|c|}{ Site No. } \\
\hline & OR7 & OR6 & OR5 & NF1 & OR4 & JC1 & OR3 & OR2 & OR1 \\
\hline Total taxa & 46 & 40 & 52 & 42 & 34 & 46 & 45 & 35 & 31 \\
\hline Ephemeroptera taxa & 11 & 9 & 11 & 5 & 13 & 7 & 10 & 5 & 10 \\
\hline Plecoptera taxa & 0 & 0 & 0 & 2 & 0 & 0 & 0 & 0 & 1 \\
\hline Trichoptera taxa & 8 & 7 & 9 & 5 & 5 & 4 & 10 & 9 & 5 \\
\hline EPT taxa ${ }^{1}$ & 19 & 16 & 20 & 12 & 18 & 11 & 20 & 14 & 16 \\
\hline Percent Plecoptera & 0 & 0 & 0 & 1.55 & 0 & 0 & 0 & 0 & .18 \\
\hline $\begin{array}{l}\text { Hilsenhoff Biotic } \\
\text { Index }\end{array}$ & 3.91 & 3.80 & 4.32 & 4.48 & 3.57 & 5.52 & 3.77 & 4.46 & 4.06 \\
\hline $\begin{array}{l}\text { Percent coldwater } \\
\operatorname{taxa}^{2}\end{array}$ & 0 & 0 & .2 & .2 & .5 & .5 & 0 & 0 & .6 \\
\hline Abundance (no. $/ \mathrm{m}^{2}$ ) & 8,457 & 14,833 & 6,396 & 3,616 & 16,864 & 8,134 & 6,039 & 8,144 & 11,733 \\
\hline
\end{tabular}

${ }^{1}$ Sum of Ephemeroptera, Plecoptera, and Trichoptera taxa.

${ }^{2}$ Obligate coldwater taxa according to Idaho Department of Environmental Quality (Grafe and others, 2002). 
Table 10. Microhabitat characteristics and periphyton results for the Owyhee River and selected tributaries, Oregon, June through July 2001

[Site locations shown in figure 2; values represent average of five measurements at riffle collection sites within each reach; No., number; $\mathrm{m}$, meters; $\mathrm{m} / \mathrm{s}$, meters per second; mm, millimeters; <, less than; mg, milligrams; $\mathrm{m}^{2}$, square meters; g, grams; multiply meters by 3.281 to obtain feet; multiply millimeters by 0.03937 to obtain inches]

\begin{tabular}{|c|c|c|c|c|c|c|c|c|c|c|c|}
\hline \multirow[b]{2}{*}{$\begin{array}{l}\text { Site } \\
\text { No. }\end{array}$} & \multirow[b]{2}{*}{ Site name } & \multirow[b]{2}{*}{$\begin{array}{l}\text { Sample } \\
\text { date }\end{array}$} & \multirow[b]{2}{*}{$\begin{array}{c}\text { Riffle } \\
\text { depth } \\
\text { (m) }\end{array}$} & \multirow[b]{2}{*}{$\begin{array}{c}\text { Riffle } \\
\text { velocity } \\
(\mathrm{m} / \mathrm{s})\end{array}$} & \multirow[b]{2}{*}{$\begin{array}{l}\text { Percent } \\
\text { substrate } \\
\text { fines } \\
<2 \mathrm{~mm}\end{array}$} & \multirow[b]{2}{*}{$\begin{array}{l}\text { Dominant } \\
\text { substrate }\end{array}$} & \multirow[b]{2}{*}{$\begin{array}{c}\text { Substrate } \\
\text { embedded- } \\
\text { ness } \\
\text { (percent) }\end{array}$} & \multirow[b]{2}{*}{$\begin{array}{c}\text { Open } \\
\text { canopy } \\
\text { (percent) }\end{array}$} & \multirow{2}{*}{$\begin{array}{c}\text { Substrate } \\
\text { covered by } \\
\text { filamentous } \\
\text { algae } \\
\text { (percent) }\end{array}$} & \multicolumn{2}{|c|}{ Periphyton } \\
\hline & & & & & & & & & & $\begin{array}{l}\text { Chlorophyll-a } \\
\left(\mathbf{m g} / \mathrm{m}^{2}\right)\end{array}$ & $\begin{array}{c}\text { Biomass' }_{\left(\mathrm{g} / \mathrm{m}^{2}\right)} \\
\end{array}$ \\
\hline OR7 & Owyhee River at State Line. . & $06-27$ & 0.26 & 0.56 & 10 & cobble/gravel & $25-50$ & 45 & 40 & 246 & 126 \\
\hline OR6 & $\begin{array}{l}\text { Owyhee River above } \\
\quad \text { West Little Owyhee River ......... }\end{array}$ & $06-26$ & .20 & .72 & 10 & cobble/gravel & $25-50$ & 80 & 80 & 25 & 11 \\
\hline OR5 & Owyhee River at Three Forks ........ & $06-25$ & .24 & .42 & 10 & cobble/gravel & $25-50$ & 74 & 30 & 28 & 11 \\
\hline NF1 & North Fork Owyhee River & $06-25$ & .14 & .40 & 20 & gravel/sand & $25-50$ & 89 & 10 & 20 & 5 \\
\hline $\mathrm{JC} 1$ & Jordan Creek near Rome... . & $06-27$ & .18 & .49 & 30 & gravel/sand & $25-50$ & 91 & 60 & 86 & 79 \\
\hline OR4 & Owyhee River near Rome .......... & $07-11$ & .17 & .64 & 20 & cobble/gravel & $25-50$ & 91 & 10 & 14 & 8 \\
\hline OR3 & Owyhee River below Crooked Creek .. & $06-28$ & .22 & .36 & 20 & cobble/gravel & $5-25$ & 83 & 10 & 47 & 22 \\
\hline OR2 & Owyhee River above Bull Creek...... & $06-28$ & .29 & .54 & $<10$ & cobble/boulder & $5-25$ & 84 & 0 & 29 & 18 \\
\hline OR1 & Owyhee River above Lake Owyhee ... & $07-11$ & .23 & .59 & 20 & cobble/gravel & $25-50$ & 76 & 0 & 15 & 8 \\
\hline
\end{tabular}

${ }^{1}$ Ash-free dry weight.
${ }^{2}$ Average of duplicates. 


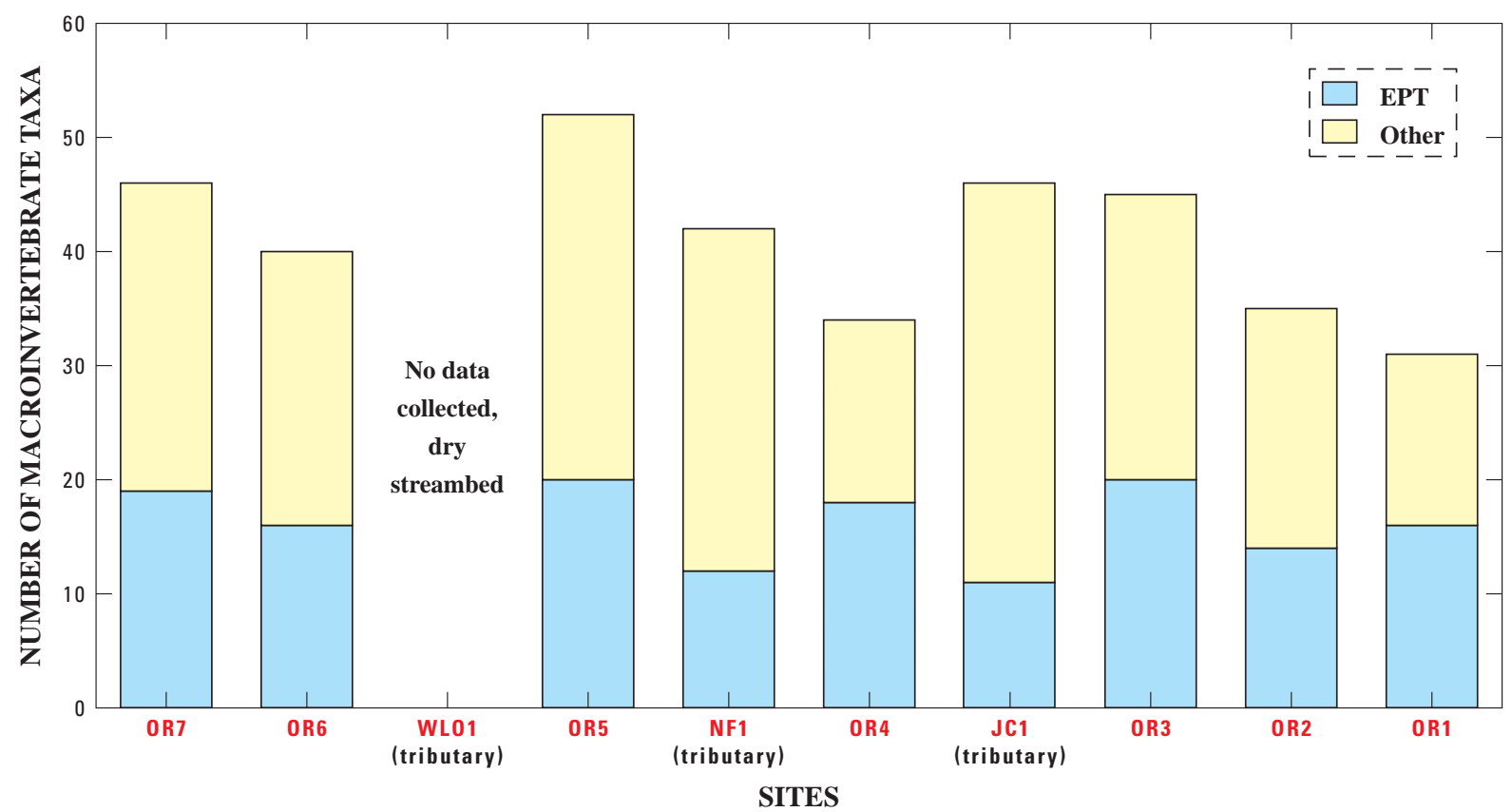

Figure 12. Number of macroinvertebrate and Ephemeroptera, Plecoptera, and Trichoptera (EPT) taxa collected at sites in the Owyhee River and selected tributaries, Oregon, June through July 2001. (Site descriptions shown in table 1; locations shown in figure 2)

taxa collected ranged from 31 to 52 at the Owyhee River above Lake Owyhee (site OR1) and Owyhee River at Three Forks (site OR5), respectively (table 8). Mochan and Mrazik (2000) sampled near site OR5 in September 1996-97 and collected 27 to 30 taxa, much fewer than the 52 taxa collected during this reconnaissance. Different laboratories were used for processing the samples, which can create inconsistencies in taxonomic identification, thus making comparison of results or detecting trends problematic (Maret and others, 2001).

The number of EPT taxa collected in the Owyhee River study area is small relative to the number usually collected in montane forested streams, where more than 30 EPT taxa from riffle habitats are common (B. Wisseman, Aquatic Biological Associates, written commun., 2002). EPT taxa generally are considered intolerant of pollution, and this metric is one of the most widely used to evaluate water-quality conditions of Northwestern streams (Hayslip, 1993). The number of EPT taxa ranged from 11 to 20 (fig. 12 and table 8). The fewest EPT taxa (11) were collected at Jordan Creek (site JC1). Mochan and Mrazik (2000) collected only 13 EPT taxa at this site in 1996 . They also reported that tolerant taxa, including $B$. tricaudatus, Tricorythodes sp., and Oligochaeta were predominant at this site. During this reconnaissance, $B$. tricaudatus and Oligochaeta were the most abundant taxa at site JC1. Oligochaete worms can tolerate low dissolved oxygen conditions well and are often abundant in areas where organic-rich sediment has accumulated. Site JC1 also contained the largest amount (30 percent) of substrate fines. These biological findings correspond with Oregon's mean water-quality index score for this site, which was rated as poor for the period 1992-97 (Mochan and Mrazik, 2000).

Plecopterans were collected only at sites NF1 and OR1, and they composed less than 2 percent of the total assemblage at these sites. As a group, Plecopterans generally are considered indicators of good water quality and habitat conditions because they are adversely affected by substrate embeddedness, low dissolved oxygen, warm water temperatures, and excessive growth of filamentous algae. Clark (1978) also noted that Plecopterans were absent in some benthic invertebrate samples collected in September 1976 at Owyhee River sites in Idaho. Reasons for their absence are unclear but are likely the high summer water temperatures and the abundance of filamentous algae at some of the sites (table 10).

The HBI scores ranged from 3.57 to 5.52 at the Owyhee River near Rome (site OR4) and Jordan Creek near Rome (site JC1), respectively (table 8 ). There was no apparent downstream trend in HBI scores at sites on the Owyhee River. However, the HBI score (> 5.0) for Jordan Creek indicates waterquality impairment.

The coldwater taxa Epeorus sp. and Perlidae were collected at sites OR5, NF1, JC1, and OR4, but they composed less than 1 percent of the total abundance at any one site (table 8). Because maximum water temperatures com- 
monly approached or exceeded $27^{\circ} \mathrm{C}$ at all sites (fig. 4), the lack of coldwater taxa at these sites is not surprising.

Potamopyrgus antipodarum (New Zealand mud snail) was collected at site OR3 (table 9). This gastropod was introduced in the 1980s in the Hagerman Valley (along the Snake River in Gooding County, downstream from Twin Falls, Idaho) by aquaculture practices (Maret and others, 2001). It has been known to reach very high densities where water quality has been degraded (such as the middle Snake River in southern Idaho), and is suspected to compete with native species for food and habitat resources.

\section{Periphyton Communities}

Samples of epilithic periphyton communities were collected at only 9 of the 10 sampling sites. Samples were not collected at site WLO1 because this tributary was not flowing during the base-flow period. Chlorophyll- $a$ concentrations were compared with proposed aggregate ecoregion criteria for the xeric West and with concentrations suggested as indicators of nuisance algal conditions (U.S. Environmental Protection Agency, 2000a and b).

There was no obvious downstream trend in the chlorophyll- $a$ and biomass (ash-free dry weight) concentrations at Owyhee River sites (table 10). Periphyton at sites OR7, JC1, and OR3 exceeded the U.S. Environmental Protection Agency proposed ecoregion chlorophyll- $a$ criterion of $44 \mathrm{mg} / \mathrm{m}^{2}$ (U.S. Environmental Protection Agency, 2000a). The community at Jordan Creek (site JC1), where 60 percent of the riffle substrates were covered with filamentous algae, had the highest biomass $\left(79 \mathrm{~g} / \mathrm{m}^{2}\right)$ and chlorophyll- $a$ concentrations (86 $\mathrm{mg} / \mathrm{m}^{2}$ ). The chlorophyll- $a$ concentration at this site approached $100 \mathrm{mg} / \mathrm{m}^{2}$, the concentration suggested as an indicator of nuisance algal conditions (U.S. Environmental Protection Agency, 2000b). Cladophora sp. was the predominant filamentous algae observed at all sites.

\section{Summary}

The Owyhee River drains about 10,950 square miles of extremely rugged and remote landscape in northern Nevada, southwestern Idaho, and eastern Oregon. The Vale District of the Bureau of Land Management must ensure that its landmanagement actions do not impair the beneficial uses of the river from the Idaho-Oregon State line to Lake Owyhee. This segment, excluding 14 miles in the Rome area, has been designated part of the National Wild and Scenic Rivers System.

More than 91 percent of the land cover in the watershed is sagebrush shrubland and grassland, and livestock grazing is the primary land use. The sparse human population is concentrated near Rome and along Jordan Creek and its tributaries, where mining, farming, and grazing are the predominant land uses. Because access to the river is so limited, few chemical and biological data are available. This reconnaissance of 10 river and tributary sites was undertaken to describe river quality, determine where major changes in water quality occur, and provide data that will help define beneficial uses and support activities related to environmental impact assessments and Total Maximum Daily Loads. Water samples were collected during a summer base flow and two spring runoff events in an attempt to bracket the range of water-quality conditions. Samples of benthic invertebrate and periphyton communities and stream-bottom materials were collected and habitat characteristics were measured to assess integrated, long-term, water-quality conditions. Major water-quality issues are summarized in figure $\mathbf{1 3}$ and discussed in the subsequent paragraphs.

Water temperatures were highest in early July through early August. Maximum temperatures ranged from $25.1^{\circ}$ to $30.9^{\circ}$ Celsius (C). Maximum 7-day average temperatures ranged from $24.2^{\circ}$ to $28.9^{\circ} \mathrm{C}$, which exceeded Oregon's recommended maximum of $17.8^{\circ} \mathrm{C}$. Summer temperatures generally were highest in the central part of the study area and just upstream from Lake Owyhee.

Suspended sediment concentrations at all sites were higher during spring runoff than during base flow. Concentrations during base flow were less than 10 milligrams per liter $(\mathrm{mg} / \mathrm{L})$ at all sites. Concentrations in the upper reaches of the study area during both spring runoff events were typically less than $20 \mathrm{mg} / \mathrm{L}$, although a peak concentration of $52 \mathrm{mg} / \mathrm{L}$ was measured at site OR5. However, during the highest runoff event (April 2002), concentrations in the lower study area at sites OR4, JC1, OR3, and OR2 commonly exceeded $50 \mathrm{mg} / \mathrm{L}$ and were as high as $142 \mathrm{mg} / \mathrm{L}$ at site OR3 below Crooked Creek. A second sampling during this runoff event indicates that these high-flow samples might not represent the highest concentrations that occurred. Despite elevated concentrations of suspended sediment in some tributaries, the loads were small compared with those transported by the Owyhee River. Spatial trends for turbidity were similar to those for suspended sediment.

Concentrations of dissolved oxygen in flowing water ranged from 7.7 to $12.2 \mathrm{mg} / \mathrm{L}$, which exceeded Oregon's minimum single-observation criterion $(5.5 \mathrm{mg} / \mathrm{L})$ recommended for warmwater aquatic life. Although few concentrations exceeded the minimum single-observation criterion for salmonid spawning $(11 \mathrm{mg} / \mathrm{L})$, most concentrations were within 95 to 133 percent of saturated conditions. Significant oxygen supersaturation during the June base flow suggests that excess production by phytoplankton might occur near Rome. In addition, the presence of large periphyton populations, generally tolerant invertebrate communities, and organisms known to tolerate low oxygen conditions in Jordan Creek indicate that this tributary might be subject to significant dissolved oxygen depletions at times. Calculations show that, even during the warmest periods, dissolved oxygen concentrations continue to exceed the minimum concentration recommended for warmwater aquatic life.

Measurements of $\mathrm{pH}$ ranged from 7.4 to 9.1. One measurement exceeded the maximum of $\mathrm{pH} 9$ recommended for eastern Oregon streams. This high $\mathrm{pH}$ was measured at 


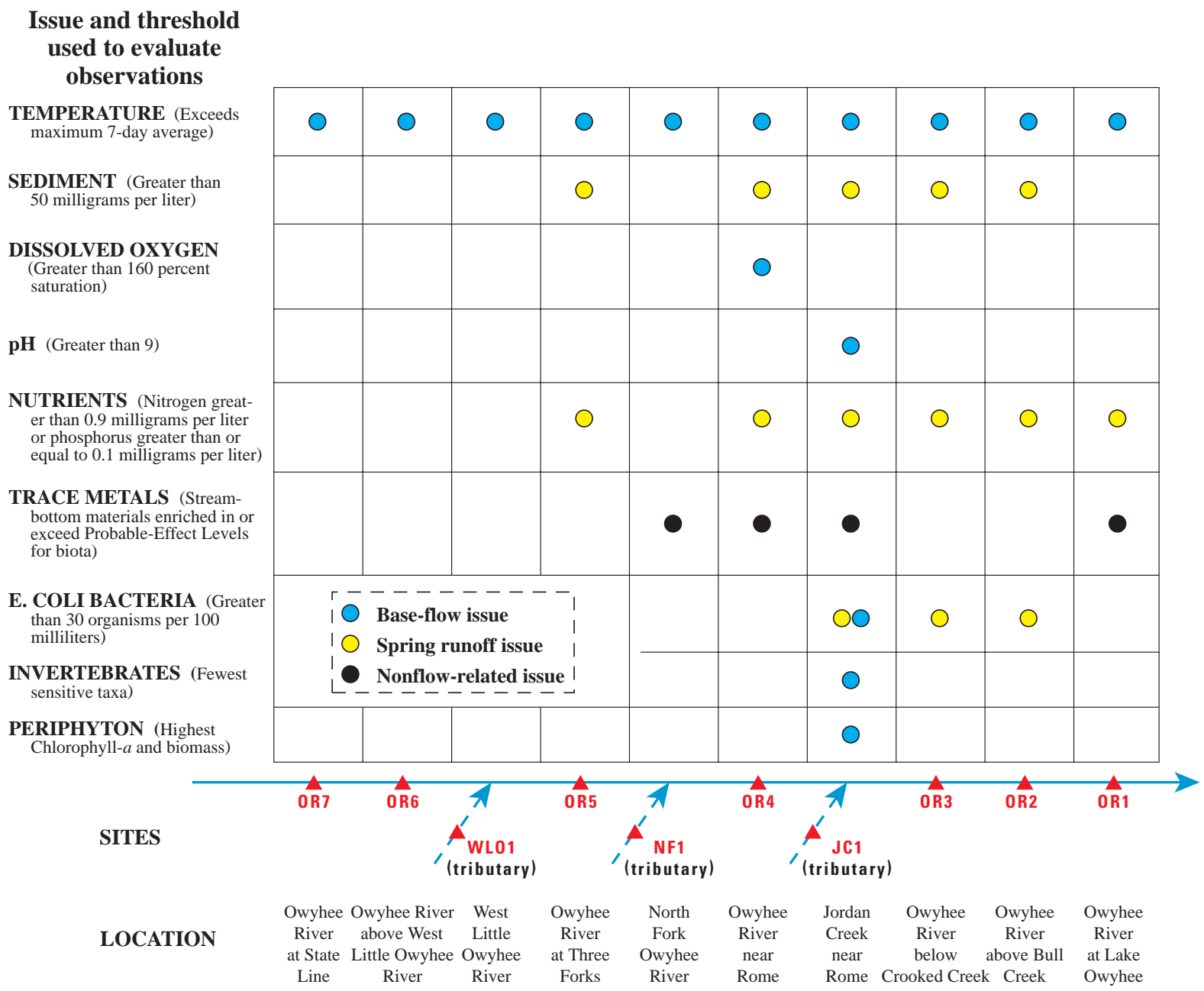

Figure 13. Summary of water-quality issues for the Owyhee River and selected tributaries, Oregon, 2001 and 2002.

Jordan Creek and is probably a result of excess production by periphyton.

For each site except North Fork, concentrations of dissolved solids were about 2 to 6 times higher during base flow (ranging from 94 to $222 \mathrm{mg} / \mathrm{L}$ ) than during spring runoff (ranging from 46 to $133 \mathrm{mg} / \mathrm{L}$ ). In contrast, dissolved solids were similar in the North Fork Owyhee River during all flow conditions (ranging from 52 to $70 \mathrm{mg} / \mathrm{L}$ ).

Sodium-dominated water with a high dissolved solids content was measured at most Owyhee River sites during base flow and suggests that most stream water was derived from ground water from low elevations. In contrast, the calciumand sodium-codominated water with a low dissolved solids content measured at Owyhee River sites in the lower part of the study area during spring runoff suggests that a large proportion of the stream water was derived from the uplands. All sodium concentrations measured were too low to cause undesirable cation exchange effects for irrigation use. However, dissolved solids concentrations during base flow were high enough to present a medium salinity hazard for irrigation.

Fluoride concentrations were generally less than $1 \mathrm{mg} / \mathrm{L}$ in tributaries and during spring runoff at Owyhee River sites but ranged from 1.7 to $2.4 \mathrm{mg} / \mathrm{L}$ during base flow. Because of the high concentrations reported in some of the geothermal springs along the river, fluoride concentrations might be able to be used to estimate the volume of hot water that these springs contribute to the river.

Total nitrogen concentrations ranged from 0.14 to $2.6 \mathrm{mg} / \mathrm{L}$, and nearly all were less than the $1.9 \mathrm{mg} / \mathrm{L}$ national median for 179 basins sampled as part of the National WaterQuality Assessment (NAWQA) Program. Concentrations were highest (exceeding $0.9 \mathrm{mg} / \mathrm{L}$ ) in the lower reaches of the study area at sites OR4, JC1, OR3, and OR2. All ammonia concentrations were at or below laboratory reporting limits. During base flow, all total nitrogen concentrations (less than $0.7 \mathrm{mg} / \mathrm{L}$ ) and inorganic nitrogen concentrations (less than or equal to $0.3 \mathrm{mg} / \mathrm{L}$ ) were generally low and uniform throughout the 
basin. Concentrations were nearly the same during the 2001 spring runoff, possibly as a result of the small amount of precipitation that the basin received during the preceding winter.

During the 2002 spring runoff, concentrations of organic and particulate nitrogen were high at all sites, particularly near Rome where organic particles (possibly dislodged periphyton and materials flushed from adjacent lands) composed most of the total nitrogen concentrations. Significant differences between concentrations in two samples collected near Rome during this runoff event indicated that these elevated concentrations might have been of short duration. Though concentrations of nitrogen in Jordan Creek were somewhat elevated, the loads that the creek transported to the Owyhee River were only about 7 to 15 percent of those transported by the Owyhee River upstream from the Jordan Creek confluence.

Total phosphorus concentrations ranged from $<0.06$ to $0.23 \mathrm{mg} / \mathrm{L}$. Most concentrations were less than the $0.18 \mathrm{mg} / \mathrm{L}$ national median for 179 basins sampled as part of the NAWQA Program. Concentrations were highest (exceeding $0.1 \mathrm{mg} / \mathrm{L}$, a threshold level for possible nuisance algal production) in the lower reaches of the study area at sites OR5, OR4, JC1, OR3, OR2, and OR1 during spring runoff. Significant differences between concentrations in two samples collected near Rome during the 2002 spring runoff indicated that these elevated concentrations might be of short duration. During base flow, total phosphorus and orthophosphate typically were not detected. During spring runoff, concentrations of organic plus particulate phosphorus were significantly higher than those during base flow and were associated with suspended sediment transport.

Loads of phosphorus transported by Jordan Creek were about 25 to 34 percent of those transported by the Owyhee River upstream from the Jordan Creek confluence. The high phosphorus load at site OR3 in April 2002 suggests that cultivated and developed lands downstream from the Jordan Creek confluence and input from Crooked Creek also may contribute significant amounts of phosphorus to the Owyhee River.

Compared with estimates from an earlier study, instantaneous loads of nitrogen discharged to the reservoir were higher in summer during this study, whereas loads of phosphorus in April 2001 were lower. Different hydrologic conditions, sampling locations, and sampling techniques probably contributed to these differences.

Eleven of 39 trace elements analyzed in stream-bottom materials were considered enriched over background study area concentrations. Data suggest that Jordan Creek and the North Fork Owyhee River may be the main sources of these metals. Manganese and mercury were elevated in Jordan Creek, probably ultimately a result of upstream mining activities. It is not known whether small reservoirs and wetlands upstream from the sampling site have roles in enhancing concentrations of these elements and depleting concentrations of others. Beryllium, cerium, copper, lanthanum, neodymium, nickel, titanium, yttrium, and zinc were enriched at the North Fork Owyhee River. Though this area is not mined, naturally enriched geologic formations and geothermal springs in the drainage basin may be the sources of these elements. Chromium, mercury, and nickel in stream-bottom materials at sites $\mathrm{NF} 1, \mathrm{OR} 4, \mathrm{JC} 1$, and OR1 were considered to have the greatest likelihood of affecting the health of bottom-dwelling organisms.

In water, arsenic concentrations were highest during base flow in the lower reaches of the study area, possibly a result of geothermal springs that discharge to the river, but were well below concentrations considered harmful to aquatic organisms. Selenium was not detected in any water samples.

Populations of Escherichia Coli bacteria ranged from $<1$ to 370 most probable number per 100 milliliters (MPN/100 mL), all less than the maximum of 406 organisms $/ 100 \mathrm{~mL}$ recommended for a single measurement in Oregon freshwater. Major sources of bacteria were near and downstream from Rome. Populations during the spring runoff and base flow in 2001 were highest ( 32 and $50 \mathrm{MPN} / 100 \mathrm{~mL}$ ) at Jordan Creek. Populations during the 2002 spring runoff were highest (140 to $370 \mathrm{MPN} / 100 \mathrm{~mL}$ ) downstream from Crooked Creek.

Aquatic insects composed most of the benthic invertebrate assemblages sampled. Total taxa collected ranged from 31 to 52 per site. Ephemeroptera, Plecoptera, and Trichoptera (EPT) taxa abundance was low compared with those in montane forested streams, ranging from 11 to 20 per site. Few Plecopterans were collected, and their absence is consistent with data from the Owyhee River in Idaho. High summer water temperatures and the abundance of filamentous algae at some of the sites might contribute to their low numbers. Coldwater taxa were rare, supporting the high summer stream temperatures that were measured. The introduced species Potamopyrgus antipodarum (New Zealand mud snail) was collected in the Owyhee River below Crooked Creek. This gastropod was introduced in the 1980s in the Hagerman Valley along the Snake River by aquaculture practices and is suspected to compete for resources with native species. The freshwater clam Gonidea angulata was collected only in the uppermost part of the study area at the Oregon State line.

No spatial trends were apparent in the numbers of taxa, community abundance, EPT taxa, or Hilsenhoff Biotic Index (HBI) scores. Jordan Creek near Rome contained the fewest EPT taxa, was dominated by the tolerant taxa Oligochaeta and $B$. tricaudatus, had the highest HBI score, and had the highest proportion of fine particles composing the stream bottom. The Owyhee River just upstream from Jordan Creek contained the most abundant invertebrate community. These measurements support the nutrient and dissolved oxygen results documenting significant water-quality impacts in Jordan Valley.

No obvious spatial trends were apparent in periphyton communities from the Owyhee River. Cladophora sp. was the predominant filamentous algae observed at all sites. Communities in and near Rome and at the Oregon State line exceeded the EPA proposed ecoregion chlorophyll- $a$ criterion of 44 milligrams per square meter $\left(\mathrm{mg} / \mathrm{m}^{2}\right)$. The concentration of chlorophyll- $a$ was highest $\left(86 \mathrm{mg} / \mathrm{m}^{2}\right)$ at Jordan Creek and 
approached the $100 \mathrm{mg} / \mathrm{m}^{2}$ concentration suggested as an indicator of nuisance algal conditions.

\section{References Cited}

American Public Health Association, American Water Works Association, and Water Environment Federation, 1995, Standard methods for the examination of water and wastewater (19th ed.): Washington, D.C., American Public Health Association, [variously paged].

1998, Standard methods for the examination of water and wastewater (20th ed.): Washington, D.C., American Public Health Association, [variously paged].

Arbogast, B.F., 1990, Quality assurance manual for the Branch of Geochemistry: U.S. Geological Survey OpenFile Report 90-668, 184 p.

Barbour, M.T., Gerristen, J., Snyder, B.D., and Stribling, J.B., 1999, Rapid bioassessment protocols for use in streams and wadeable rivers - periphyton, benthic macroinvertebrates, and fish, 2d ed.: Washington, D.C., U.S. Environmental Protection Agency, Office of Water, EPA841-B99-002, [variously paged].

Batts, David, and Cubbage, Jim, 1995, Summary of guidelines for contaminated freshwater sediments: Olympia, Wash., Washington State Department of Ecology publication no. 95-308, 2 p.

Briggs, P.H., and Meier, A.L., 1999, The determination of forty-two elements in geological materials by inductively coupled plasma-mass spectrometry, in Arbogast, B.F., ed., Analytical methods manual for the Mineral Resource Surveys Program: U.S. Geological Survey Open-File Report 96-525, p. 76-88.

Clark, W.H., 1978, Water quality status report, Owyhee River, Owyhee County, Idaho 1976-77: Boise, Idaho Department of Health and Welfare, Division of Environment, Water Quality Status Series no. 35, 73 p.

Craft, Douglas, Cannon, Norbert, Zimmer, David, Krill, Karl, and DiMattia, Louis, 2000, Water quality and mercury in Lake Owyhee, southeastern Oregon: U.S. Department of the Interior, Bureau of Reclamation, $232 \mathrm{p}$.

Cuffney, T.F., Gurtz, M.E., and Meador, M.R., 1993, Methods for collecting benthic invertebrate samples as part of the National Water-Quality Assessment Program: U.S. Geological Survey Open-File Report 93-406, 66 p.

Essig, D.A., 1998, The dilemma of applying uniform temperature criteria in a diverse environment: an issue analysis: Boise, Idaho Division of Environmental Quality, 29 p.

Fishman, M.J., ed., 1993, Methods of analysis by the U.S. Geological Survey National Water Quality Laboratorydetermination of inorganic and organic constituents in water and fluvial sediments: U.S Geological Survey Open-File Report 93-125, 217 p.

Fishman, M.J., and Friedman, L.C., eds., 1989, Methods for determination of inorganic substances in water and flu- vial sediments: U.S. Geological Survey Techniques of Water-Resources Investigations, book 5, chap. A1, 545 p.

Fitzpatrick, F.A., Waite, I.R., D'Arconte, P.J., Meador, M.R., Maupin, M.A., and Gurtz, M.E., 1998, Revised methods for characterizing stream habitat in the National WaterQuality Assessment Program: U.S. Geological Survey Water-Resources Investigations Report 98-4052, 67 p.

Friedman, L.C., and Erdmann, D.E., 1982, Quality assurance practices for the chemical and biological analyses of water and fluvial sediments: U.S. Geological Survey Techniques of Water-Resources Investigations, book 5, chap. A6, $181 \mathrm{p}$

Grafe, C.S., Mebane, C.A., McIntyre, M.J., Essig, D.A., Brandt, D.H., and Mosier, S.T., 2002, The Idaho Department of Environmental Quality Water Body Assessment Guidance, 2d ed., final: Boise, Idaho Department of Environmental Quality, [variously paged].

Guy, H.P., 1969, Laboratory theory and methods for sediment analysis: U.S. Geological Survey Techniques of WaterResources Investigations, book 5, chap. C1, 58 p.

Hardy, M.A., 1984, Chemical and biological quality of streams at the Indiana Dunes National Lakeshore, Indiana, 1978-80: U.S. Geological Survey WaterResources Investigations 83-4208, 95 p.

Hayslip, G.A., 1993, Region 10 in-stream biological monitoring handbook for wadable streams in the Pacific Northwest: Seattle, Wash., U.S. Environmental Protection Agency, Environmental Services Division, 75 p.

Hem, J.D., 1985, Study and interpretation of the chemical characteristics of natural water ( $3 \mathrm{~d}$ ed.): U.S. Geological Survey Water-Supply Paper 2254, 264 p.

Horowitz, A.J., 1991, A primer on sediment-trace element chemistry, 2d ed: Chelsea, Mich., Lewis Publishers, Inc., $136 \mathrm{p}$.

Karr, J.R., Fausch, K.D., Angermeier, P.L., Yant, P.R., and Schlosser, I.J., 1986, Assessing biological integrity in running waters - a method and its rationale: Illinois Natural History Survey, Special Publication 5, 29 p.

Koerber, S., 1995, Mercury in the Owyhee River Basin, Oregon, Idaho, and Nevada: Portland, Oreg., Oregon Department of Environmental Quality, Mercury Working Group.

Lydy, M.J., Crawford, C.G., and Frey, J.W., 2000, A comparison of selected diversity, similarity, and biotic indices for detecting changes in benthic invertebrate community structure and stream quality: Archives of Environmental Contamination and Toxicology, v. 39, p. 469-479.

Mackenthun, K.M., 1969, The practice of water pollution biology: U.S. Department of the Interior, Federal Water Pollution Control Administration, Division of Technical Support, $281 \mathrm{p}$.

Maret, T.R., MacCoy, D.E., Skinner, K.D., Moore, S.E., and O'Dell, I., 2001, Evaluation of macroinvertebrate assemblages in Idaho rivers using multimetric and multivariate techniques, 1996-98: U.S. Geological Survey WaterResources Investigations Report 01-4145, 69 p. 
Mariner, R.H., Young, H.W., and Evans, W.C., 1994, Chemical, isotopic, and dissolved gas compositions of the hot springs of the Owyhee Uplands, Malheur County, Oregon: Transactions of the Geothermal Resources Council, v. 18, p. 221-228.

Mochan, D.G., and Mrazik, S., 2000, A summary of chemistry, temperature, habitat, and macroinvertebrate data from the southeast Oregon ambient monitoring sites (1992-1998): Oregon Department of Environmental Quality, Laboratory Division, Technical Report no. BIO00-03, 27 p.

Moulton, S.R., II, Carter, J.L., Grotheer, S.A., Cuffney, T.F., and Short, T.M., 2000, Methods of analysis by the U.S. Geological Survey National Water Quality Laboratoryprocessing, taxonomy, and quality control of benthic macroinvertebrate samples: U.S. Geological Survey Open-File Report 00-212, 49 p.

Oregon Department of Environmental Quality, 2002, Oregon Administrative Rules, Chapter 340, Rules 340-0410842 and 340-041-0845: accessed September 2003 at URL http://arcweb.sos.state.or.us/rules/OARs_300/ OAR_340/340_041.html

Porter, S.D., Cuffney, T.F., Gurtz, M.E., and Meador, M.R., 1993, Methods for collecting algal samples as part of the National Water-Quality Assessment Program: U.S. Geological Survey Open-File Report 93-409, 39 p.

Pritt, J.W., and Raese, J.W., eds., 1995, Quality assurance/quality control manual, National Water Quality Laboratory: U.S. Geological Survey Open-File Report 95-443, 35 p.

Radtke, D.B., 1997, Bottom-material samples, in National field manual for the collection of water-quality data: U.S. Geological Survey Techniques of Water-Resources Investigations, book 9, chap. A8, 48 p.
Rickert, D.A., Kennedy, V.C., McKenzie, S.W., and Hines, W.G., 1977, A synoptic survey of trace metals in bottom sediments of the Willamette River, Oregon: U.S. Geological Survey Circular 715-F, 27 p.

Rinella, F.A., Mullins, W.H., and Schuler, C.A., 1994, Reconnaissance investigation of water quality, bottom sediment, and biota associated with irrigation drainage in the Owyhee and Vale projects, Oregon and Idaho, 1990-91: U.S. Geological Survey Water-Resources Investigations Report 93-4156, $101 \mathrm{p}$.

Ryding, S.O., and Rast, Walter, eds., 1989, The control of eutrophication of lakes and reservoirs, v. 1 of Programme on man and the biosphere series: Cambridge University Press, 295 p.

Stiff, H.A., Jr., 1951, The interpretation of chemical water analysis by means of patterns: Journal of Petroleum Technology, v. 3, no. 10, p. 15-17.

U.S. Environmental Protection Agency, 2000a, National nutrient criteria development: accessed May 2001, at URL http://www.epa.gov/OST/standards/nutrient.html 2000b, Nutrient criteria technical guidance manual, rivers and streams: accessed May 2001, at URL http://www.epa.gov/OST/standards/nutrient.html 2002, National recommended water quality criteria, 2002: U.S. Environmental Protection Agency, EPA822-R-02-047, $33 \mathrm{p}$.

Velz, C.J., 1970, Applied stream sanitation: New York, John Wiley and Sons, Inc., 619 p.

Wilde, F.D., Radtke, D.B., Gibs, J., and Iwatsubo, R.T., eds., 1999, Collection of water samples and processing of water samples, in national field manual for the collection of water-quality data: U.S. Geological Survey Techniques of Water-Resources Investigations, book 9, chaps. A4 and A5, [variously paged]. 


\section{Tables 3 and 9}


Table 3. Onsite measurements and chemical analyses of water and bottom-material samples collected from the Owyhee River and selected tributaries, Oregon, 2001 and 2002

[Site locations shown in figure 2 ; bed sed, bed sediment; $\mathrm{CaCO}_{3}$, calcium carbonate; cfs, cubic feet per second; deg C, degrees Celsius; E, estimated value; E. coli, Escherichia coliform; fld, field; fltrd, filtered; Hg, mercury; inorg, inorganic; mg/L, milligrams per liter; mL, milliliters; mm, millimeters; MPN, most probable number; nat, native water; NTU, nephelometric turbidity units; org-N, organic nitrogen; P, phosphorus; rec, recoverable; std, standard; svd, sieved; tot, total; $\mu \mathrm{g} / \mathrm{g}$, micrograms per gram; $\mu \mathrm{g} / \mathrm{L}$, micrograms per liter; $\mu \mathrm{m}$, micrometers; $\mu \mathrm{S} / \mathrm{cm}$, microsiemens per centimeter; unf, unfltrd, unfiltered; wat, water; wsv, wet sieved; <, less than; >, greater than; -, no data]

\begin{tabular}{|c|c|c|c|c|c|c|c|c|c|c|c|c|c|c|}
\hline Site & Date & Time & $\begin{array}{c}\text { Instan- } \\
\text { taneous } \\
\text { dis- } \\
\text { charge, } \\
\text { cfs } \\
(00061) \\
\end{array}$ & $\begin{array}{c}\text { Turbid- } \\
\text { ity, } \\
\text { wat unf } \\
\text { lab, } \\
\text { Hach } \\
\text { 2100AN } \\
\text { NTU } \\
\text { (99872) }\end{array}$ & $\begin{array}{c}\text { Baro- } \\
\text { metric } \\
\text { pres- } \\
\text { sure, } \\
\text { mm Hg } \\
(00025)\end{array}$ & $\begin{array}{c}\text { Dis- } \\
\text { solved } \\
\text { oxygen, } \\
\text { mg/L } \\
(00300)\end{array}$ & $\begin{array}{c}\text { Dis- } \\
\text { solved } \\
\text { oxygen, } \\
\text { percent } \\
\text { of sat- } \\
\text { uration } \\
\text { (00301) }\end{array}$ & $\begin{array}{c}\text { pH, } \\
\text { water, } \\
\text { unfltrd } \\
\text { field, } \\
\text { std } \\
\text { units } \\
\text { (00400) }\end{array}$ & $\begin{array}{c}\text { Specific } \\
\text { conduc- } \\
\text { tance, } \\
\text { wat unf } \\
\mu \mathrm{s} / \mathrm{cm} \\
25 \mathrm{deg} C \\
\text { (00095) }\end{array}$ & $\begin{array}{c}\text { Temper- } \\
\text { ature, } \\
\text { air, } \\
\text { deg C } \\
(00020)\end{array}$ & $\begin{array}{c}\text { Temper- } \\
\text { ature, } \\
\text { water, } \\
\text { deg C } \\
(00010)\end{array}$ & $\begin{array}{c}\text { Calcium } \\
\text { water, } \\
\text { fltrd, } \\
\text { mg/L } \\
\text { (00915) }\end{array}$ & $\begin{array}{c}\text { Magnes- } \\
\text { ium, } \\
\text { water, } \\
\text { fltrd, } \\
\text { mg/L } \\
\text { (00925) }\end{array}$ & $\begin{array}{c}\text { Potas- } \\
\text { sium, } \\
\text { water, } \\
\text { fltrd, } \\
\text { mg/L } \\
\text { (00935) }\end{array}$ \\
\hline OR7 & $\begin{array}{l}04-09-01 \\
06-27-01 \\
04-22-02\end{array}$ & $\begin{array}{l}1600 \\
0815 \\
1300\end{array}$ & $\begin{array}{r}534 \\
84 \\
846\end{array}$ & $\begin{array}{l}13 \\
1.1 \\
19\end{array}$ & $\begin{array}{r}652 \\
- \\
659\end{array}$ & $\begin{array}{c}10.9 \\
- \\
9.8\end{array}$ & $\begin{array}{r}101 \\
- \\
98\end{array}$ & $\begin{array}{l}7.8 \\
8.3 \\
7.9\end{array}$ & $\begin{array}{l}170 \\
314 \\
134\end{array}$ & $\begin{array}{r}4.5 \\
19.0 \\
-\end{array}$ & $\begin{array}{r}5.6 \\
18.0 \\
8.9\end{array}$ & $\begin{array}{l}17.4 \\
23.7 \\
14.6\end{array}$ & $\begin{array}{l}4.25 \\
8.71 \\
3.56\end{array}$ & $\begin{array}{l}2.80 \\
4.91 \\
2.43\end{array}$ \\
\hline OR6 & $\begin{array}{l}04-10-01 \\
06-26-01 \\
04-15-02\end{array}$ & $\begin{array}{l}1330 \\
0830 \\
1605\end{array}$ & $\begin{array}{r}463 \\
86 \\
1060\end{array}$ & $\begin{array}{l}12 \\
1.4 \\
17\end{array}$ & $\begin{array}{l}654 \\
654 \\
655\end{array}$ & $\begin{array}{r}10.5 \\
8.9 \\
9.8\end{array}$ & $\begin{array}{r}97 \\
110 \\
103\end{array}$ & $\begin{array}{l}8.0 \\
8.5 \\
7.6\end{array}$ & $\begin{array}{l}179 \\
313 \\
104\end{array}$ & $\begin{array}{l}7.5 \\
- \\
-\end{array}$ & $\begin{array}{r}5.5 \\
18.0 \\
10.9\end{array}$ & $\begin{array}{l}17.4 \\
23.8 \\
11.7\end{array}$ & $\begin{array}{l}4.23 \\
8.48 \\
2.97\end{array}$ & $\begin{array}{l}2.67 \\
5.20 \\
2.45\end{array}$ \\
\hline WLO1 & $\begin{array}{l}04-10-01 \\
06-26-01 \\
04-15-02\end{array}$ & $\begin{array}{l}1450 \\
1115 \\
1715\end{array}$ & ${ }_{280}^{31} .54$ & $\begin{array}{l}3.2 \\
1.2 \\
11\end{array}$ & $\begin{array}{l}653 \\
655 \\
655\end{array}$ & $\begin{array}{r}10.6 \\
4.7 \\
10.1\end{array}$ & $\begin{array}{r}101 \\
59 \\
101\end{array}$ & $\begin{array}{l}8.2 \\
7.7 \\
7.4\end{array}$ & $\begin{array}{r}102 \\
141 \\
45\end{array}$ & $\begin{array}{l}8.0 \\
- \\
-\end{array}$ & $\begin{array}{r}6.5 \\
18.5 \\
8.5\end{array}$ & $\begin{array}{c}8.11 \\
11.0 \\
3.92\end{array}$ & $\begin{array}{l}2.18 \\
3.05 \\
1.16\end{array}$ & $\begin{array}{l}1.78 \\
3.52 \\
1.50\end{array}$ \\
\hline OR5 & $\begin{array}{l}04-17-01 \\
06-25-01 \\
04-11-02\end{array}$ & $\begin{array}{l}1235 \\
1200 \\
1230\end{array}$ & $\begin{array}{r}1260 \\
116 \\
2070\end{array}$ & $\begin{array}{l}53 \\
5.2 \\
39\end{array}$ & $\begin{array}{l}660 \\
657 \\
669\end{array}$ & $\begin{array}{l}- \\
7.7 \\
9.5\end{array}$ & $\begin{array}{l}- \\
99 \\
96\end{array}$ & $\begin{array}{l}7.6 \\
8.6 \\
7.8\end{array}$ & $\begin{array}{r}105 \\
319 \\
99\end{array}$ & $\begin{array}{l}17.5 \\
23.0 \\
16.0\end{array}$ & $\begin{array}{r}11.6 \\
20.0 \\
9.8\end{array}$ & $\begin{array}{c}8.96 \\
22.6 \\
8.94\end{array}$ & $\begin{array}{l}2.42 \\
7.02 \\
2.40\end{array}$ & $\begin{array}{l}2.07 \\
4.34 \\
2.10\end{array}$ \\
\hline OR4 & $\begin{array}{l}04-04-01 \\
06-28-01 \\
04-03-02 \\
04-12-02\end{array}$ & $\begin{array}{l}1245 \\
1715 \\
1230 \\
0915\end{array}$ & $\begin{array}{r}866 \\
148 \\
5490 \\
2510\end{array}$ & $\begin{array}{l}13 \\
1.2 \\
64 \\
22\end{array}$ & $\begin{array}{l}677 \\
675 \\
672 \\
681\end{array}$ & $\begin{array}{r}11.2 \\
11.9 \\
11.1 \\
9.6\end{array}$ & $\begin{array}{r}108 \\
161 \\
107 \\
97\end{array}$ & $\begin{array}{l}7.7 \\
8.9 \\
7.5 \\
7.9\end{array}$ & $\begin{array}{r}150 \\
299 \\
53 \\
91\end{array}$ & $\begin{array}{r}8.5 \\
30.0 \\
18.0 \\
13.0\end{array}$ & $\begin{array}{r}8.5 \\
24.3 \\
8.3 \\
10.6\end{array}$ & $\begin{array}{l}14.3 \\
20.5 \\
4.15 \\
8.34\end{array}$ & $\begin{array}{l}3.74 \\
6.07 \\
1.30 \\
2.34\end{array}$ & $\begin{array}{l}2.41 \\
4.17 \\
1.68 \\
2.02\end{array}$ \\
\hline JC1 & $\begin{array}{l}04-02-01 \\
06-27-01 \\
04-12-02\end{array}$ & $\begin{array}{l}1345 \\
1600 \\
1210\end{array}$ & $\begin{array}{r}58 \\
20 \\
494\end{array}$ & $\begin{array}{l}41 \\
2.6 \\
41\end{array}$ & $\begin{array}{r}666 \\
- \\
682\end{array}$ & $\begin{array}{c}11.4 \\
- \\
9.9\end{array}$ & $\begin{array}{r}116 \\
- \\
101\end{array}$ & $\begin{array}{l}7.9 \\
9.1 \\
7.8\end{array}$ & $\begin{array}{r}164 \\
318 \\
85\end{array}$ & $\begin{array}{r}6.5 \\
27.0 \\
14.0\end{array}$ & $\begin{array}{l}10.0 \\
21.4 \\
11.1\end{array}$ & $\begin{array}{c}15.3 \\
26.9 \\
7.92\end{array}$ & $\begin{array}{l}4.33 \\
8.50 \\
2.39\end{array}$ & $\begin{array}{l}3.37 \\
5.34 \\
1.85\end{array}$ \\
\hline OR3 & $\begin{array}{l}04-12-01 \\
06-28-01 \\
04-16-02\end{array}$ & $\begin{array}{l}1145 \\
0900 \\
1245\end{array}$ & $\begin{array}{r}779 \\
191 \\
2970\end{array}$ & $\begin{array}{l}9.8 \\
2.9 \\
96\end{array}$ & $\begin{array}{l}676 \\
675 \\
674\end{array}$ & $\begin{array}{r}10.1 \\
8.5 \\
9.5\end{array}$ & $\begin{array}{r}93 \\
106 \\
93\end{array}$ & $\begin{array}{l}7.8 \\
8.3 \\
8.1\end{array}$ & $\begin{array}{r}171 \\
338 \\
95\end{array}$ & $\begin{array}{r}7.5 \\
23.0 \\
-\end{array}$ & $\begin{array}{r}6.5 \\
20.0 \\
9.0\end{array}$ & $\begin{array}{c}14.4 \\
21.5 \\
7.89\end{array}$ & $\begin{array}{l}3.70 \\
6.21 \\
2.27\end{array}$ & $\begin{array}{l}2.61 \\
4.83 \\
2.22\end{array}$ \\
\hline OR2 & $\begin{array}{l}04-12-01 \\
06-28-01 \\
04-16-02\end{array}$ & $\begin{array}{l}1745 \\
1215 \\
1015\end{array}$ & $\begin{array}{r}923 \\
248 \\
3130\end{array}$ & $\begin{array}{l}10 \\
1.5 \\
44\end{array}$ & $\begin{array}{r}- \\
690 \\
674\end{array}$ & $\begin{array}{r}- \\
10.6 \\
9.4\end{array}$ & $\begin{array}{r}- \\
133 \\
95\end{array}$ & $\begin{array}{l}8.1 \\
8.6 \\
7.6\end{array}$ & $\begin{array}{l}180 \\
325 \\
102\end{array}$ & $\begin{array}{c}- \\
29.0 \\
-\end{array}$ & $\begin{array}{c}- \\
21.5 \\
10.2\end{array}$ & $\begin{array}{c}15.0 \\
21.0 \\
8.83\end{array}$ & $\begin{array}{l}3.84 \\
5.99 \\
2.51\end{array}$ & $\begin{array}{l}2.71 \\
4.81 \\
2.11\end{array}$ \\
\hline OR1 & $\begin{array}{l}04-03-01 \\
06-29-01 \\
04-10-02\end{array}$ & $\begin{array}{l}1245 \\
0815 \\
1330\end{array}$ & $\begin{array}{r}1170 \\
287 \\
3330\end{array}$ & $\begin{array}{l}20 \\
2.4 \\
30\end{array}$ & $\begin{array}{l}688 \\
683 \\
698\end{array}$ & $\begin{array}{l}9.8 \\
8.0 \\
8.5\end{array}$ & $\begin{array}{r}96 \\
101 \\
86\end{array}$ & $\begin{array}{l}7.6 \\
8.5 \\
8.0\end{array}$ & $\begin{array}{r}140 \\
343 \\
91\end{array}$ & $\begin{array}{r}4.5 \\
23.0 \\
-\end{array}$ & $\begin{array}{l}10.0 \\
21.0 \\
11.9\end{array}$ & $\begin{array}{c}11.3 \\
20.9 \\
6.96\end{array}$ & $\begin{array}{l}3.16 \\
6.09 \\
2.07\end{array}$ & $\begin{array}{l}2.46 \\
4.92 \\
1.94\end{array}$ \\
\hline
\end{tabular}


Table 3. Onsite measurements and chemical analyses of water and bottom-material samples collected from the 0wyhee River and selected tributaries, Oregon, 2001 and 2002Continued

\begin{tabular}{|c|c|c|c|c|c|c|c|c|c|c|c|c|c|c|}
\hline Site & Date & $\begin{array}{c}\text { Sodium, } \\
\text { water, } \\
\text { fltrd, } \\
\text { mg/L } \\
(00930)\end{array}$ & $\begin{array}{c}\text { Alka- } \\
\text { linity, } \\
\text { lab, } \\
\mathrm{mg} / \mathrm{L} \text { as } \\
\mathrm{CaCO} 3 \\
(\mathbf{9 0 4 1 0 )}\end{array}$ & $\begin{array}{c}\text { Chlor- } \\
\text { ide, } \\
\text { water, } \\
\text { fltrd, } \\
\text { mg/L } \\
(00940)\end{array}$ & $\begin{array}{c}\text { Fluor- } \\
\text { ide, } \\
\text { water, } \\
\text { fltrd, } \\
\text { mg/L } \\
(00950)\end{array}$ & $\begin{array}{c}\text { Silica, } \\
\text { water, } \\
\text { fltrd, } \\
\text { mg/L } \\
(00955)\end{array}$ & $\begin{array}{c}\text { Sulfate, } \\
\text { water, } \\
\text { fltrd, } \\
\mathrm{mg} / \mathrm{L} \\
(00945)\end{array}$ & $\begin{array}{c}\text { Residue } \\
\text { water, } \\
\text { fltrd, } \\
\text { sum of } \\
\text { consti- } \\
\text { tuents, } \\
\text { mg/L } \\
(70301)\end{array}$ & $\begin{array}{c}\text { Ammonia } \\
+ \\
\text { org-N, } \\
\text { water, } \\
\text { fltrd, } \\
\text { mg/L } \\
\text { as N } \\
(00623)\end{array}$ & $\begin{array}{c}\text { Ammonia } \\
+ \\
\text { org-N, } \\
\text { water, } \\
\text { unfltrd, } \\
\text { mg/L } \\
\text { as N } \\
(00625)\end{array}$ & $\begin{array}{c}\text { Ammonia } \\
\text { water, } \\
\text { fltrd, } \\
\text { mg/L } \\
\text { as N } \\
\text { (00608) }\end{array}$ & $\begin{array}{c}\text { Nitrite } \\
+ \\
\text { nitrate } \\
\text { water, } \\
\text { fltrd, } \\
\mathrm{mg} / \mathrm{L} \\
\text { as N } \\
\text { (00631) }\end{array}$ & $\begin{array}{c}\text { Nitrite } \\
\text { water, } \\
\text { fltrd, } \\
\mathrm{mg} / \mathrm{L} \\
\text { as N } \\
\text { (00613) }\end{array}$ & $\begin{array}{c}\text { Ortho- } \\
\text { phos- } \\
\text { phate, } \\
\text { water, } \\
\text { fltrd, } \\
\text { mg/L } \\
\text { as P } \\
\text { (00671) }\end{array}$ \\
\hline OR7 & $\begin{array}{l}04-09-01 \\
06-27-01 \\
04-22-02\end{array}$ & $\begin{array}{c}13.0 \\
30.7 \\
9.71\end{array}$ & $\begin{array}{r}74 \\
137 \\
64\end{array}$ & $\begin{array}{l}4.85 \\
8.21 \\
3.39\end{array}$ & $\begin{array}{r}0.7 \\
1.8 \\
.4\end{array}$ & $\begin{array}{l}24.1 \\
19.2 \\
23.2\end{array}$ & $\begin{array}{r}10.5 \\
14.7 \\
7.5\end{array}$ & $\begin{array}{l}122 \\
194 \\
104\end{array}$ & $\begin{array}{r}0.29 \\
.28 \\
.33\end{array}$ & $\begin{array}{r}0.47 \\
.34 \\
.45\end{array}$ & $\begin{array}{r}<0.04 \\
\text { E.03 } \\
<.04\end{array}$ & $\begin{array}{r}\text { E0.03 } \\
<.05 \\
.05\end{array}$ & $\begin{array}{r}<0.006 \\
.008 \\
<.008\end{array}$ & $\begin{array}{r}\text { E0.01 } \\
<.02 \\
.02\end{array}$ \\
\hline OR6 & $\begin{array}{l}04-10-01 \\
06-26-01 \\
04-15-02\end{array}$ & $\begin{array}{c}13.3 \\
31.0 \\
9.25\end{array}$ & $\begin{array}{r}74 \\
137 \\
53\end{array}$ & $\begin{array}{l}5.00 \\
8.10 \\
3.93\end{array}$ & $\begin{array}{r}.7 \\
1.7 \\
.6\end{array}$ & $\begin{array}{l}24.6 \\
16.8 \\
23.1\end{array}$ & $\begin{array}{r}10.6 \\
15.1 \\
6.8\end{array}$ & $\begin{array}{r}123 \\
192 \\
93\end{array}$ & $\begin{array}{l}.21 \\
.29 \\
.32\end{array}$ & $\begin{array}{l}.40 \\
.36 \\
.49\end{array}$ & $\begin{array}{l}<.04 \\
\text { E.03 } \\
<.04\end{array}$ & $\begin{array}{r}<.05 \\
<.05 \\
.07\end{array}$ & $\begin{array}{r}<.006 \\
.009 \\
<.008\end{array}$ & $\begin{array}{r}\text { E.01 } \\
<.02 \\
.03\end{array}$ \\
\hline WLO1 & $\begin{array}{l}04-10-01 \\
06-26-01 \\
04-15-02\end{array}$ & $\begin{array}{c}8.88 \\
11.8 \\
4.75\end{array}$ & $\begin{array}{l}39 \\
54 \\
23\end{array}$ & $\begin{array}{l}4.70 \\
6.16 \\
1.47\end{array}$ & $\begin{array}{l}.3 \\
.3 \\
.2\end{array}$ & $\begin{array}{l}15.8 \\
18.6 \\
18.6\end{array}$ & $\begin{array}{l}5.5 \\
7.1 \\
2.1\end{array}$ & $\begin{array}{l}71 \\
94 \\
48\end{array}$ & $\begin{array}{r}\text { E.10 } \\
<.10 \\
.20\end{array}$ & $\begin{array}{l}.18 \\
.08 \\
.30\end{array}$ & $\begin{array}{l}<.04 \\
\text { E.03 } \\
<.04\end{array}$ & $\begin{array}{r}<.05 \\
.06 \\
<.05\end{array}$ & $\begin{array}{r}<.006 \\
.009 \\
<.008\end{array}$ & $\begin{array}{r}\text { E.02 } \\
.02 \\
\text { E.01 }\end{array}$ \\
\hline OR5 & $\begin{array}{l}04-17-01 \\
06-25-01 \\
04-11-02\end{array}$ & $\begin{array}{c}8.89 \\
36.6 \\
7.68\end{array}$ & $\begin{array}{r}44 \\
132 \\
42\end{array}$ & $\begin{array}{l}2.13 \\
9.97 \\
3.13\end{array}$ & $\begin{array}{r}.4 \\
2.2 \\
.5\end{array}$ & $\begin{array}{l}20.3 \\
21.7 \\
21.4\end{array}$ & $\begin{array}{r}5.1 \\
17.3 \\
5.6\end{array}$ & $\begin{array}{r}77 \\
201 \\
78\end{array}$ & $\begin{array}{l}.31 \\
.29 \\
.24\end{array}$ & $\begin{array}{l}.72 \\
.34 \\
.50\end{array}$ & $\begin{array}{l}<.04 \\
<.04 \\
<.04\end{array}$ & $\begin{array}{r}\text { E.03 } \\
.14 \\
.09\end{array}$ & $\begin{array}{l}<.006 \\
\text { E.004 } \\
<.008\end{array}$ & $\begin{array}{r}\text { E.02 } \\
<.02 \\
.03\end{array}$ \\
\hline NF1 & $\begin{array}{l}04-17-01 \\
06-25-01 \\
04-11-02\end{array}$ & $\begin{array}{l}3.82 \\
5.61 \\
3.22\end{array}$ & $\begin{array}{l}25 \\
38 \\
25\end{array}$ & $\begin{array}{r}.62 \\
1.49 \\
.84\end{array}$ & $\begin{array}{r}\text { E. } 1 \\
.2 \\
\text { E. } 1\end{array}$ & $\begin{array}{l}24.1 \\
26.2 \\
24.6\end{array}$ & $\begin{array}{l}1.3 \\
2.0 \\
1.3\end{array}$ & $\begin{array}{l}52 \\
70 \\
52\end{array}$ & $\begin{array}{l}.18 \\
.15 \\
.17\end{array}$ & $\begin{array}{l}.30 \\
.20 \\
.33\end{array}$ & $\begin{array}{l}<.04 \\
<.04 \\
<.04\end{array}$ & $\begin{array}{r}<.05 \\
<.05 \\
.08\end{array}$ & $\begin{array}{l}<.006 \\
<.006 \\
<.008\end{array}$ & $\begin{array}{l}<.02 \\
<.02 \\
\text { E.01 }\end{array}$ \\
\hline OR4 & $\begin{array}{l}04-04-01 \\
06-28-01 \\
04-03-02 \\
04-12-02\end{array}$ & $\begin{array}{c}12.0 \\
37.0 \\
4.34 \\
7.60\end{array}$ & $\begin{array}{r}61 \\
122 \\
23 \\
40\end{array}$ & $\begin{array}{l}3.92 \\
9.68 \\
1.24 \\
2.53\end{array}$ & $\begin{array}{r}.7 \\
2.4 \\
.2 \\
.5\end{array}$ & $\begin{array}{l}25.2 \\
23.9 \\
16.3 \\
22.0\end{array}$ & $\begin{array}{r}8.6 \\
16.7 \\
2.1 \\
4.9\end{array}$ & $\begin{array}{r}108 \\
194 \\
46 \\
75\end{array}$ & $\begin{array}{l}.20 \\
.25 \\
.19 \\
.24\end{array}$ & $\begin{array}{l}.40 \\
.19 \\
.71 \\
2.5\end{array}$ & $\begin{array}{l}<.04 \\
\text { E.03 } \\
<.04 \\
<.04\end{array}$ & $\begin{array}{r}.10 \\
\text { E.04 } \\
.10 \\
.12\end{array}$ & $\begin{array}{r}<.006 \\
.007 \\
<.008 \\
<.008\end{array}$ & $\begin{array}{r}.02 \\
\text { E.02 } \\
.03 \\
.03\end{array}$ \\
\hline JC1 & $\begin{array}{l}04-02-01 \\
06-27-01 \\
04-12-02\end{array}$ & $\begin{array}{c}12.1 \\
30.8 \\
6.38\end{array}$ & $\begin{array}{r}61 \\
140 \\
34\end{array}$ & $\begin{array}{l}3.28 \\
6.71 \\
1.42\end{array}$ & $\begin{array}{l}.3 \\
.7 \\
.3\end{array}$ & $\begin{array}{l}25.3 \\
26.8 \\
25.3\end{array}$ & $\begin{array}{r}15.7 \\
22.5 \\
8.6\end{array}$ & $\begin{array}{r}118 \\
213 \\
76\end{array}$ & $\begin{array}{l}.33 \\
.47 \\
.26\end{array}$ & $\begin{array}{l}.85 \\
.64 \\
.57\end{array}$ & $\begin{array}{l}<.04 \\
\text { E.03 } \\
<.04\end{array}$ & $\begin{array}{r}.31 \\
<.05 \\
.34\end{array}$ & $\begin{array}{r}\text { E.005 } \\
.009 \\
<.008\end{array}$ & $\begin{array}{l}.03 \\
.04 \\
.03\end{array}$ \\
\hline OR3 & $\begin{array}{l}04-12-01 \\
06-28-01 \\
04-16-02\end{array}$ & $\begin{array}{c}16.8 \\
43.20 \\
8.20\end{array}$ & $\begin{array}{r}71 \\
138 \\
39\end{array}$ & $\begin{array}{c}5.24 \\
10.8 \\
3.34\end{array}$ & $\begin{array}{r}.8 \\
2.2 \\
.5\end{array}$ & $\begin{array}{l}26.3 \\
28.2 \\
22.8\end{array}$ & $\begin{array}{r}10.9 \\
21.5 \\
6.2\end{array}$ & $\begin{array}{r}124 \\
222 \\
78\end{array}$ & $\begin{array}{l}.22 \\
.25 \\
.27\end{array}$ & $\begin{array}{l}.40 \\
.34 \\
.92\end{array}$ & $\begin{array}{r}<.04 \\
.05 \\
<.04\end{array}$ & $\begin{array}{l}.09 \\
.10 \\
.22\end{array}$ & $\begin{array}{r}<.006 \\
.006 \\
<.008\end{array}$ & $\begin{array}{r}\text { E.01 } \\
.05 \\
.02\end{array}$ \\
\hline OR2 & $\begin{array}{l}04-12-01 \\
06-28-01 \\
04-16-02\end{array}$ & $\begin{array}{c}18.7 \\
40.7 \\
9.28\end{array}$ & $\begin{array}{r}74 \\
129 \\
44\end{array}$ & $\begin{array}{c}5.85 \\
11.2 \\
3.25\end{array}$ & $\begin{array}{r}.9 \\
2.0 \\
.6\end{array}$ & $\begin{array}{l}28.1 \\
32.3 \\
24.0\end{array}$ & $\begin{array}{r}12.4 \\
23.8 \\
7.2\end{array}$ & $\begin{array}{r}133 \\
221 \\
85\end{array}$ & $\begin{array}{l}.21 \\
.22 \\
.25\end{array}$ & $\begin{array}{l}.37 \\
.30 \\
.70\end{array}$ & $\begin{array}{l}<.04 \\
\text { E.02 } \\
<.04\end{array}$ & $\begin{array}{l}.17 \\
.30 \\
.21\end{array}$ & $\begin{array}{r}<.006 \\
.010 \\
<.008\end{array}$ & $\begin{array}{r}\text { E.02 } \\
<.02 \\
.02\end{array}$ \\
\hline OR1 & $\begin{array}{l}04-03-01 \\
06-29-01 \\
04-10-02\end{array}$ & $\begin{array}{c}13.3 \\
42.1 \\
7.89\end{array}$ & $\begin{array}{r}56 \\
130 \\
36\end{array}$ & $\begin{array}{c}4.17 \\
11.0 \\
2.97\end{array}$ & $\begin{array}{r}.7 \\
2.0 \\
.4\end{array}$ & $\begin{array}{l}26.2 \\
29.4 \\
21.1\end{array}$ & $\begin{array}{r}9.5 \\
25.3 \\
5.8\end{array}$ & $\begin{array}{r}105 \\
220 \\
72\end{array}$ & $\begin{array}{l}.23 \\
.21 \\
.21\end{array}$ & $\begin{array}{l}.51 \\
.32 \\
.48\end{array}$ & $\begin{array}{l}<.04 \\
\text { E.03 } \\
<.04\end{array}$ & $\begin{array}{l}.21 \\
.19 \\
.14\end{array}$ & $\begin{array}{r}<.006 \\
.011 \\
<.008\end{array}$ & $\begin{array}{r}.02 \\
\text { E.01 } \\
.03\end{array}$ \\
\hline
\end{tabular}


Table 3. Onsite measurements and chemical analyses of water and bottom-material samples collected from the Owyhee River and selected tributaries, Oregon, 2001 and 2002 Continued

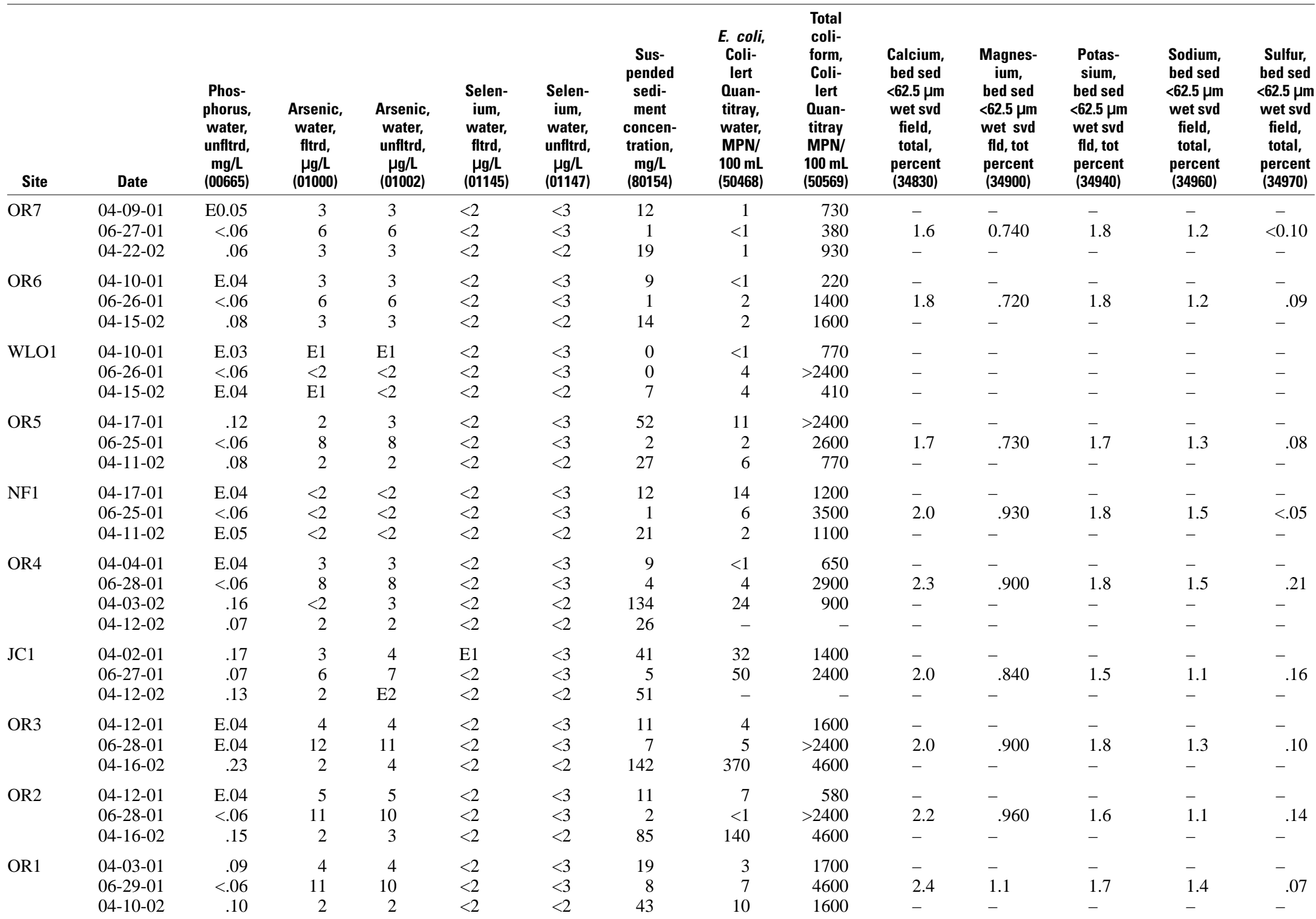


Table 3. Onsite measurements and chemical analyses of water and bottom-material samples collected from the Owyhee River and selected tributaries, Oregon, 2001 and 2002-Continued

\begin{tabular}{|c|c|c|c|c|c|c|c|c|c|c|c|c|}
\hline Site & Date & $\begin{array}{c}\text { Phos- } \\
\text { phorus, } \\
\text { bed sed } \\
<62.5 \mu \mathrm{m} \\
\text { wet svd } \\
\text { fld, tot, } \\
\text { percent } \\
\text { (34935) } \\
\end{array}$ & $\begin{array}{c}\text { Total } \\
\text { carbon, } \\
\text { bed sed } \\
<62.5 \mu \mathrm{m} \\
\text { wsv nat } \\
\text { field, } \\
\text { percent } \\
\text { (49267) } \\
\end{array}$ & $\begin{array}{c}\text { Inorg. } \\
\text { carbon, } \\
\text { bed sed } \\
<62.5 \mu \mathrm{m} \\
\text { wsv nat } \\
\text { field, } \\
\text { percent } \\
\text { (49269) }\end{array}$ & $\begin{array}{c}\text { Organic } \\
\text { carbon, } \\
\text { bed sed } \\
<62.5 \mu \mathrm{m} \\
\text { wsv nat } \\
\text { field, } \\
\text { percent } \\
\text { (49266) } \\
\end{array}$ & 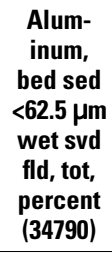 & $\begin{array}{c}\begin{array}{c}\text { Anti- } \\
\text { mony, } \\
\text { bed sed } \\
<62.5 \mu \mathrm{m} \\
\text { wet svd } \\
\text { fld, tot, } \\
\mu \mathrm{g} / \mathrm{g} \\
(34795)\end{array} \\
\end{array}$ & $\begin{array}{c}\text { Arsenic, } \\
\text { bed sed } \\
<62.5 \mu \mathrm{m} \\
\text { wet svd } \\
\text { field, } \\
\text { total, } \\
\mu \mathrm{g} / \mathrm{g} \\
(34800) \\
\end{array}$ & $\begin{array}{c}\text { Barium, } \\
\text { bed sed } \\
<62.5 \mu \mathrm{m} \\
\text { wet svd } \\
\text { field, } \\
\text { total, } \\
\mu \mathrm{g} / \mathrm{g} \\
(34805) \\
\end{array}$ & $\begin{array}{c}\text { Beryll- } \\
\text { ium, } \\
\text { bed sed } \\
<62.5 \mu \mathrm{m} \\
\text { wet svd } \\
\text { fld, tot, } \\
\mu \mathrm{g} / \mathrm{g} \\
(34810) \\
\end{array}$ & $\begin{array}{c}\text { Bismuth, } \\
\text { bed sed } \\
<62.5 \mu \mathrm{m} \\
\text { wet svd } \\
\text { field, } \\
\text { total, } \\
\mu \mathrm{g} / \mathrm{g} \\
(34816) \\
\end{array}$ & $\begin{array}{c}\text { Cadmium, } \\
\text { bed sed } \\
<62.5 \mu \mathrm{m} \\
\text { wet svd } \\
\text { field, } \\
\text { total, } \\
\mu \mathrm{g} / \mathrm{g} \\
(34825) \\
\end{array}$ \\
\hline \multirow[t]{3}{*}{ OR7 } & 04-09-01 & - & - & - & - & - & - & - & - & - & - & - \\
\hline & $06-27-01$ & 0.095 & 2.4 & 0.02 & 2.4 & 6.8 & 1.5 & 7.3 & 880 & 2.0 & $<1$ & 0.4 \\
\hline & $04-22-02$ & - & - & - & - & - & - & - & - & - & - & - \\
\hline \multirow[t]{3}{*}{ OR6 } & 04-10-01 & - & - & - & - & - & - & - & - & - & - & - \\
\hline & $06-26-01$ & .100 & 2.9 & .07 & 2.8 & 6.6 & 1.4 & 7.5 & 860 & 1.9 & $<1$ & .4 \\
\hline & $04-15-02$ & - & - & - & - & - & - & - & - & - & - & - \\
\hline \multirow[t]{3}{*}{ WLO1 } & 04-10-01 & - & - & - & - & - & - & - & - & - & - & - \\
\hline & $06-26-01$ & - & - & - & - & - & - & - & - & - & - & - \\
\hline & $04-15-02$ & - & - & - & - & - & - & - & - & - & - & - \\
\hline \multirow[t]{3}{*}{ OR5 } & 04-17-01 & - & - & - & - & - & - & - & - & - & - & - \\
\hline & $06-25-01$ & .094 & 2.4 & .03 & 2.4 & 6.9 & 1.4 & 7.7 & 810 & 2.1 & $<1$ & .4 \\
\hline & 04-11-02 & - & - & - & - & - & - & - & - & - & - & - \\
\hline \multirow[t]{3}{*}{ NF1 } & $04-17-01$ & - & - & - & - & - & - & - & - & - & - & - \\
\hline & $06-25-01$ & .092 & 2.2 & .01 & 2.2 & 7.7 & .7 & 6.1 & 730 & 2.6 & $<1$ & .3 \\
\hline & 04-11-02 & - & - & - & - & - & - & - & - & - & - & - \\
\hline \multirow[t]{4}{*}{ OR4 } & 04-04-01 & - & - & - & - & - & - & - & - & - & - & - \\
\hline & $06-28-01$ & .091 & 1.4 & .03 & 1.4 & 7.2 & 1.1 & 8.1 & 890 & 1.8 & $<1$ & .3 \\
\hline & 04-03-02 & - & - & - & - & - & & & & & & \\
\hline & $04-12-02$ & - & - & - & - & - & - & - & - & - & - & - \\
\hline \multirow[t]{3}{*}{ JC1 } & 04-02-01 & - & - & - & - & - & - & - & - & - & - & - \\
\hline & $06-27-01$ & .180 & 4.2 & .09 & 4.1 & 6.1 & .9 & 8.7 & 660 & 1.6 & $<1$ & .3 \\
\hline & $04-12-02$ & - & - & - & - & - & - & - & - & - & - & - \\
\hline \multirow[t]{3}{*}{ OR3 } & $04-12-01$ & - & - & - & - & - & - & - & - & - & - & - \\
\hline & $06-28-01$ & .120 & 2.8 & .04 & 2.8 & 6.6 & 1.0 & 9.1 & 850 & 1.8 & $<1$ & .3 \\
\hline & $04-16-02$ & - & - & - & - & - & - & - & - & - & - & - \\
\hline \multirow[t]{3}{*}{ OR2 } & $04-12-01$ & - & - & - & - & - & - & - & - & - & - & - \\
\hline & $06-28-01$ & .120 & 3.8 & .09 & 3.7 & 5.9 & .9 & 7.4 & 720 & 1.7 & $<1$ & .3 \\
\hline & 04-16-02 & - & - & - & - & - & - & - & - & - & - & - \\
\hline \multirow[t]{3}{*}{ OR1 } & 04-03-01 & - & - & - & - & - & - & - & - & - & - & - \\
\hline & $06-29-01$ & .089 & 1.7 & .01 & 1.7 & 7.1 & 1.0 & 7.0 & 880 & 1.8 & $<1$ & .2 \\
\hline & $04-10-02$ & - & - & - & - & - & - & - & - & - & - & - \\
\hline
\end{tabular}


Table 3. Onsite measurements and chemical analyses of water and bottom-material samples collected from the Owyhee River and selected tributaries, Oregon, 2001 and 2002-Continued

\begin{tabular}{|c|c|c|c|c|c|c|c|c|c|c|c|c|}
\hline Site & Date & $\begin{array}{c}\text { Cerium, } \\
\text { bed sed } \\
<62.5 \mu \mathrm{m} \\
\text { wet svd } \\
\text { field, } \\
\text { total, } \\
\mu \mathrm{g} / \mathrm{g} \\
(\mathbf{3 4 8 3 5 )}\end{array}$ & $\begin{array}{c}\text { Chrom- } \\
\text { ium, } \\
\text { bed sed } \\
<62.5 \mu \mathrm{m} \\
\text { wet svd } \\
\text { fld, tot } \\
\mu \mathrm{g} / \mathrm{g} \\
(34840)\end{array}$ & $\begin{array}{c}\text { Cobalt, } \\
\text { bed sed } \\
<62.5 \mu \mathrm{m} \\
\text { wet svd } \\
\text { field, } \\
\text { total, } \\
\mu \mathrm{g} / \mathrm{g} \\
(34845)\end{array}$ & $\begin{array}{c}\text { Copper, } \\
\text { bed sed } \\
<62.5 \mu \mathrm{m} \\
\text { wet svd } \\
\text { field, } \\
\text { total, } \\
\mu \mathrm{g} / \mathrm{g} \\
(34850)\end{array}$ & $\begin{array}{c}\text { Europ- } \\
\text { ium, } \\
\text { bed sed } \\
<62.5 \mu \mathrm{m} \\
\text { wet svd } \\
\text { fld, tot, } \\
\mu \mathrm{g} / \mathrm{g} \\
(34855)\end{array}$ & $\begin{array}{c}\text { Gallium, } \\
\text { bed sed } \\
<62.5 \mu \mathrm{m} \\
\text { wet svd } \\
\text { field, } \\
\text { total, } \\
\mu \mathrm{g} / \mathrm{g} \\
(34860)\end{array}$ & $\begin{array}{c}\text { Gold, } \\
\text { bed sed } \\
<62.5 \mu \mathrm{m} \\
\text { wet svd } \\
\text { field, } \\
\text { total, } \\
\mu \mathrm{g} / \mathrm{g} \\
(34870)\end{array}$ & $\begin{array}{c}\text { Holmium, } \\
\text { bed sed } \\
<62.5 \mu \mathrm{m} \\
\text { wet svd } \\
\text { field, } \\
\text { total, } \\
\mu \mathrm{g} / \mathrm{g} \\
(34875)\end{array}$ & $\begin{array}{c}\text { Iron, } \\
\text { bed sed } \\
<62.5 \mu \mathrm{m} \\
\text { wet svd } \\
\text { field, } \\
\text { total, } \\
\text { percent } \\
(34880)\end{array}$ & $\begin{array}{c}\text { Lantha- } \\
\text { num, } \\
\text { bed sed } \\
<62.5 \mu \mathrm{m} \\
\text { wet svd } \\
\text { fld, tot, } \\
\mu \mathrm{g} / \mathrm{g} \\
(34885)\end{array}$ & $\begin{array}{c}\text { Lead, } \\
\text { bed sed } \\
<62.5 \mu \mathrm{mm} \\
\text { wet svd } \\
\text { field, } \\
\text { total, } \\
\mu \mathrm{g} / \mathrm{g} \\
(34890)\end{array}$ \\
\hline \multirow[t]{3}{*}{ OR7 } & 04-09-01 & - & - & - & - & - & - & - & - & - & - & - \\
\hline & $06-27-01$ & 76 & 58 & 10 & 32 & 1 & 18 & $<1$ & 1 & 3.1 & 40 & 18 \\
\hline & $04-22-02$ & - & - & - & - & - & - & - & - & - & - & - \\
\hline \multirow[t]{3}{*}{ OR6 } & 04-10-01 & - & - & - & - & - & - & - & - & - & - & - \\
\hline & $06-26-01$ & 69 & 54 & 9 & 31 & 1 & 17 & $<1$ & 1 & 3.0 & 37 & 17 \\
\hline & $04-15-02$ & - & - & - & - & - & - & - & - & - & - & - \\
\hline \multirow[t]{3}{*}{ WLO1 } & 04-10-01 & - & - & - & - & - & - & - & - & - & - & - \\
\hline & $06-26-01$ & - & - & - & - & - & - & - & - & - & - & - \\
\hline & $04-15-02$ & - & - & - & - & - & - & - & - & - & - & - \\
\hline \multirow[t]{3}{*}{ OR5 } & 04-17-01 & - & - & - & - & - & - & - & - & - & - & - \\
\hline & $06-25-01$ & 80 & 66 & 12 & 34 & 1 & 18 & $<1$ & 1 & 3.3 & 41 & 18 \\
\hline & 04-11-02 & - & - & - & - & - & - & - & - & - & - & - \\
\hline \multirow[t]{3}{*}{ NF1 } & $04-17-01$ & - & - & - & - & - & - & - & - & - & - & - \\
\hline & $06-25-01$ & 110 & 95 & 18 & 43 & 2 & 21 & $<1$ & 2 & 4.5 & 57 & 19 \\
\hline & 04-11-02 & - & - & - & - & - & - & - & - & - & - & - \\
\hline \multirow[t]{4}{*}{ OR4 } & 04-04-01 & - & - & - & - & - & - & - & - & - & - & - \\
\hline & 06-28-01 & 81 & 100 & 12 & 33 & 1 & 19 & $<1$ & 1 & 3.9 & 44 & 17 \\
\hline & 04-03-02 & - & - & - & - & - & - & - & - & - & - & - \\
\hline & $04-12-02$ & - & - & - & - & - & - & - & - & - & - & - \\
\hline \multirow[t]{3}{*}{$\mathrm{JC} 1$} & 04-02-01 & - & - & - & - & - & - & - & - & - & - & - \\
\hline & $06-27-01$ & 53 & 60 & 13 & 32 & 1 & 16 & $<1$ & $<1$ & 3.5 & 27 & 14 \\
\hline & $04-12-02$ & - & - & - & - & - & - & - & - & - & - & - \\
\hline \multirow[t]{3}{*}{ OR3 } & $04-12-01$ & - & - & - & - & - & - & - & - & - & - & - \\
\hline & $06-28-01$ & 66 & 72 & 12 & 32 & 1 & 17 & $<1$ & 1 & 3.6 & 36 & 16 \\
\hline & 04-16-02 & - & - & - & - & - & - & - & - & - & - & - \\
\hline \multirow[t]{3}{*}{ OR2 } & $04-12-01$ & - & - & - & - & - & - & - & - & - & - & - \\
\hline & $06-28-01$ & 59 & 88 & 12 & 31 & 1 & 15 & $<1$ & 1 & 3.3 & 32 & 14 \\
\hline & 04-16-02 & - & - & - & - & - & - & - & - & - & - & - \\
\hline \multirow[t]{3}{*}{ OR1 } & 04-03-01 & - & - & - & - & - & - & - & - & - & - & - \\
\hline & 06-29-01 & 75 & 110 & 15 & 38 & 1 & 18 & $<1$ & 1 & 4.2 & 40 & 16 \\
\hline & $04-10-02$ & - & - & - & - & - & - & - & - & - & - & - \\
\hline
\end{tabular}


Table 3. Onsite measurements and chemical analyses of water and bottom-material samples collected from the Owyhee River and selected tributaries, Oregon, 2001 and 2002-Continued

\begin{tabular}{|c|c|c|c|c|c|c|c|c|c|c|c|c|}
\hline Site & Date & $\begin{array}{c}\text { Lithium, } \\
\text { bed sed } \\
<62.5 \mu \mathrm{m} \\
\text { wet svd } \\
\text { field, } \\
\text { total, } \\
\mu \mathrm{g} / \mathrm{g} \\
(34895)\end{array}$ & $\begin{array}{c}\text { Mangan- } \\
\text { ese, } \\
\text { bed sed } \\
<62.5 \mu \mathrm{m} \\
\text { wet svd } \\
\text { fld, tot } \\
\mu \mathrm{g} / \mathrm{g} \\
(34905)\end{array}$ & $\begin{array}{c}\text { Mercury, } \\
\text { bed sed } \\
<62.5 \mu \mathrm{m} \\
\text { wet svd } \\
\text { field, } \\
\text { total, } \\
\mu \mathrm{g} / \mathrm{g} \\
(34910)\end{array}$ & $\begin{array}{c}\text { Molyb- } \\
\text { denum, } \\
\text { bed sed } \\
<62.5 \mu \mathrm{m} \\
\text { wet svd } \\
\text { fld, tot } \\
\mu \mathrm{g} / \mathrm{g} \\
(34915)\end{array}$ & $\begin{array}{c}\text { Neodym- } \\
\text { ium, } \\
\text { bed sed } \\
<62.5 \mu \mathrm{m} \\
\text { wet svd } \\
\text { fld, tot } \\
\mu \mathrm{g} / \mathrm{g} \\
(34920)\end{array}$ & $\begin{array}{c}\text { Nickel, } \\
\text { bed sed } \\
<62.5 \mu \mathrm{m} \\
\text { wet svd } \\
\text { field, } \\
\text { total, } \\
\mu \mathrm{g} / \mathrm{g} \\
(34925)\end{array}$ & $\begin{array}{c}\text { Niobium, } \\
\text { bed sed } \\
<62.5 \mu \mathrm{m} \\
\text { wet svd } \\
\text { field, } \\
\text { total, } \\
\mu \mathrm{g} / \mathrm{g} \\
(34930)\end{array}$ & $\begin{array}{c}\text { Scand- } \\
\text { ium, } \\
\text { bed sed } \\
<62.5 \mu \mathrm{m} \\
\text { wet svd } \\
\text { fld, tot } \\
\mu \mathrm{g} / \mathrm{g} \\
(34945)\end{array}$ & $\begin{array}{c}\text { Selen- } \\
\text { ium, } \\
\text { bed sed } \\
<62.5 \mu \mathrm{m} \\
\text { wet svd } \\
\text { fld, tot } \\
\mu \mathrm{g} / \mathrm{g} \\
(34950)\end{array}$ & $\begin{array}{c}\text { Silver, } \\
\text { bed sed } \\
<62.5 \mu \mathrm{m} \\
\text { wet svd } \\
\text { field, } \\
\text { total, } \\
\mu \mathrm{g} / \mathrm{g} \\
(34955)\end{array}$ & $\begin{array}{c}\text { Stront- } \\
\text { ium, } \\
\text { bed sed } \\
<62.5 \mu \mathrm{m} \\
\text { wet svd } \\
\text { fld, tot } \\
\mu \mathrm{g} / \mathrm{g} \\
(34965)\end{array}$ \\
\hline \multirow[t]{3}{*}{ OR7 } & 04-09-01 & - & - & - & - & - & - & - & - & - & - & - \\
\hline & $06-27-01$ & 33 & 780 & 0.07 & 0.9 & 36 & 20 & 23 & 10 & 0.5 & 0.4 & 240 \\
\hline & $04-22-02$ & - & - & - & - & - & - & - & - & - & - & - \\
\hline \multirow[t]{3}{*}{ OR6 } & 04-10-01 & - & - & - & - & - & - & - & - & - & - & - \\
\hline & $06-26-01$ & 33 & 840 & .08 & .7 & 32 & 19 & 21 & 9 & .5 & .4 & 240 \\
\hline & $04-15-02$ & - & - & - & - & - & - & - & - & - & - & - \\
\hline \multirow[t]{3}{*}{ WLO1 } & 04-10-01 & - & - & - & - & - & - & - & - & - & - & - \\
\hline & $06-26-01$ & - & - & - & - & - & - & - & - & - & - & - \\
\hline & $04-15-02$ & - & - & - & - & - & - & - & - & - & - & - \\
\hline \multirow[t]{3}{*}{ OR5 } & $04-17-01$ & - & - & - & - & - & - & - & - & - & - & - \\
\hline & $06-25-01$ & 34 & 700 & .07 & .9 & 36 & 23 & 22 & 10 & .4 & .3 & 240 \\
\hline & 04-11-02 & - & - & - & - & - & - & - & - & - & - & - \\
\hline \multirow[t]{3}{*}{ NF1 } & 04-17-01 & - & - & - & - & - & - & - & - & - & - & - \\
\hline & $06-25-01$ & 31 & 780 & .05 & 1.1 & 51 & 38 & 28 & 14 & .3 & .4 & 220 \\
\hline & 04-11-02 & - & - & - & - & - & - & - & - & - & - & - \\
\hline \multirow[t]{4}{*}{ OR4 } & 04-04-01 & - & - & - & - & - & - & - & - & - & - & - \\
\hline & $06-28-01$ & 33 & 600 & .04 & 1.1 & 38 & 25 & 25 & 12 & .4 & .4 & 290 \\
\hline & 04-03-02 & - & - & - & - & - & - & - & - & - & - & - \\
\hline & 04-12-02 & - & - & - & - & - & - & - & - & - & - & - \\
\hline \multirow[t]{3}{*}{$\mathrm{JC} 1$} & $04-02-01$ & - & - & - & - & - & - & - & - & - & - & - \\
\hline & $06-27-01$ & 27 & 1700 & .86 & 1.1 & 26 & 27 & 18 & 10 & .9 & .5 & 220 \\
\hline & 04-12-02 & - & - & - & - & - & - & - & - & - & - & - \\
\hline \multirow[t]{3}{*}{ OR3 } & $04-12-01$ & - & - & - & - & - & - & - & - & - & - & - \\
\hline & $06-28-01$ & 32 & 760 & .13 & 1.0 & 31 & 26 & 18 & 11 & .5 & .3 & 240 \\
\hline & 04-16-02 & - & - & - & - & - & - & - & - & - & - & - \\
\hline \multirow[t]{3}{*}{ OR2 } & $04-12-01$ & - & - & - & - & - & - & - & - & - & - & - \\
\hline & $06-28-01$ & 37 & 630 & .13 & 1.3 & 28 & 27 & 20 & 10 & .6 & .3 & 220 \\
\hline & $04-16-02$ & - & - & - & - & - & - & - & - & - & - & - \\
\hline \multirow[t]{3}{*}{ OR1 } & 04-03-01 & - & - & - & - & - & - & - & - & - & - & - \\
\hline & $06-29-01$ & 39 & 560 & .28 & 1.0 & 35 & 34 & 22 & 13 & .4 & .4 & 290 \\
\hline & 04-10-02 & - & - & - & - & - & - & - & - & - & - & - \\
\hline
\end{tabular}


Table 3. Onsite measurements and chemical analyses of water and bottom-material samples collected from the Owyhee River and selected tributaries, Oregon, 2001 and 2002 - Continued

\begin{tabular}{|c|c|c|c|c|c|c|c|c|c|c|c|}
\hline Site & Date & $\begin{array}{c}\text { Tant- } \\
\text { alum, } \\
\text { bed sed } \\
<62.5 \mu \mathrm{m} \\
\text { wet svd } \\
\text { fld, tot } \\
\mu \mathrm{g} / \mathrm{g} \\
(34975) \\
\end{array}$ & $\begin{array}{c}\text { Thall- } \\
\text { ium, } \\
\text { bed sed } \\
<62.5 \mu \mathrm{m} \\
\text { dry svd } \\
\text { total, } \\
\mu \mathrm{g} / \mathrm{g} \\
(04064) \\
\end{array}$ & $\begin{array}{c}\text { Thorium } \\
\text { bed sed } \\
<62.5 \mu \mathrm{m} \\
\text { wet svd } \\
\text { field, } \\
\text { total, } \\
\mu \mathrm{g} / \mathrm{g} \\
(34980) \\
\end{array}$ & $\begin{array}{c}\text { Tin, } \\
\text { bed sed } \\
<62.5 \mu \mathrm{m} \\
\text { wet svd } \\
\text { field, } \\
\text { total, } \\
\mu \mathrm{g} / \mathrm{g} \\
(34985) \\
\end{array}$ & 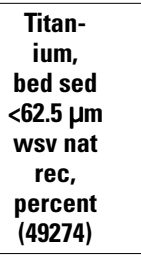 & 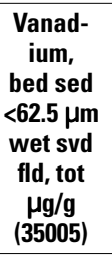 & $\begin{array}{c}\begin{array}{c}\text { Ytterb- } \\
\text { ium, } \\
\text { bed sed }\end{array} \\
<62.5 \mu \mathrm{m} \\
\text { wet svd } \\
\text { fld, tot } \\
\mu \mathrm{g} / \mathrm{g} \\
(35015) \\
\end{array}$ & $\begin{array}{c}\text { Yttrium, } \\
\text { bed sed } \\
<62.5 \mu \mathrm{m} \\
\text { wet svd } \\
\text { field, } \\
\text { total, } \\
\mu \mathrm{g} / \mathrm{g} \\
(35010) \\
\end{array}$ & $\begin{array}{c}\text { Zinc, } \\
\text { bed sed } \\
<62.5 \mu \mathrm{m} \\
\text { wet svd } \\
\text { field, } \\
\text { total, } \\
\mu \mathrm{g} / \mathrm{g} \\
(35020) \\
\end{array}$ & $\begin{array}{c}\text { Uranium } \\
\text { bed sed } \\
<62.5 \mu \mathrm{m} \\
\text { wet svd } \\
\text { field, } \\
\text { total } \\
\mu \mathrm{g} / \mathrm{g} \\
(35000) \\
\end{array}$ \\
\hline \multirow[t]{3}{*}{ OR7 } & 04-09-01 & - & - & - & - & - & - & - & - & - & - \\
\hline & $06-27-01$ & 2 & $<1$ & 12 & 3 & 0.460 & 82 & 3 & 30 & 93 & 3.8 \\
\hline & $04-22-02$ & - & - & - & - & - & - & - & - & - & - \\
\hline \multirow[t]{3}{*}{ OR6 } & 04-10-01 & - & - & - & - & - & - & - & - & - & - \\
\hline & $06-26-01$ & 1 & $<1$ & 11 & 3 & .440 & 74 & 2 & 28 & 91 & 3.0 \\
\hline & $04-15-02$ & - & - & - & - & - & - & - & - & - & - \\
\hline \multirow[t]{3}{*}{ WLO1 } & 04-10-01 & - & - & - & - & - & - & - & - & - & - \\
\hline & $06-26-01$ & - & - & - & - & - & - & - & - & - & - \\
\hline & $04-15-02$ & - & - & - & - & - & - & - & - & - & - \\
\hline \multirow[t]{3}{*}{ OR5 } & 04-17-01 & - & - & - & - & - & - & - & - & - & - \\
\hline & $06-25-01$ & $<1$ & $<1$ & 12 & 3 & .510 & 85 & 3 & 33 & 90 & 4.0 \\
\hline & 04-11-02 & - & - & - & - & - & - & - & - & - & - \\
\hline \multirow[t]{3}{*}{ NF1 } & 04-17-01 & - & - & - & - & - & - & - & - & - & - \\
\hline & $06-25-01$ & 2 & $<1$ & 15 & 4 & .750 & 120 & 5 & 54 & 110 & 4.8 \\
\hline & 04-11-02 & - & - & - & - & - & - & - & - & - & - \\
\hline \multirow[t]{4}{*}{ OR4 } & 04-04-01 & - & - & - & - & - & - & - & - & - & - \\
\hline & $06-28-01$ & 1 & $<1$ & 12 & 3 & .780 & 120 & 3 & 32 & 97 & 3.6 \\
\hline & 04-03-02 & - & - & - & - & - & - & - & - & - & - \\
\hline & $04-12-02$ & - & - & - & - & - & - & - & - & - & - \\
\hline \multirow[t]{3}{*}{ JC1 } & 04-02-01 & - & - & - & - & - & - & - & - & - & - \\
\hline & $06-27-01$ & $<1$ & $<1$ & 8 & 2 & .550 & 94 & 2 & 25 & 91 & 2.1 \\
\hline & $04-12-02$ & - & - & - & - & - & - & - & - & - & - \\
\hline \multirow[t]{3}{*}{ OR3 } & $04-12-01$ & - & - & - & - & - & - & - & - & - & - \\
\hline & $06-28-01$ & $<1$ & $<1$ & 11 & 3 & .560 & 98 & 3 & 29 & 89 & 3.0 \\
\hline & 04-16-02 & - & - & - & - & - & - & - & - & - & - \\
\hline \multirow[t]{3}{*}{ OR2 } & $04-12-01$ & - & - & - & - & - & - & - & - & - & - \\
\hline & $06-28-01$ & $<1$ & $<1$ & 10 & 2 & .570 & 97 & 2 & 26 & 84 & 3.0 \\
\hline & 04-16-02 & - & - & - & - & - & - & - & - & - & - \\
\hline \multirow[t]{3}{*}{ OR1 } & 04-03-01 & - & - & - & - & - & - & - & - & - & - \\
\hline & $06-29-01$ & 1 & $<1$ & 12 & 3 & .750 & 120 & 3 & 32 & 99 & 3.4 \\
\hline & $04-10-02$ & - & - & - & - & - & - & - & - & - & - \\
\hline
\end{tabular}


Table 9. Benthic invertebrate abundance in the Owyhee River and selected tributaries, Oregon, June through July, 2001

[Site locations shown in figure 2; abundance reported in number of individuals per square meter (no./ $/ \mathrm{m}^{2}$ ); USGS, U.S. Geological Survey: ID, identification]

\begin{tabular}{|c|c|c|c|c|c|c|c|c|c|c|}
\hline Site name... & $\begin{array}{c}\text { Owyhee River } \\
\text { at } \\
\text { State Line }\end{array}$ & $\begin{array}{l}\text { Owyhee River } \\
\text { above } \\
\text { West Little } \\
\text { Owyhee River }\end{array}$ & $\begin{array}{c}\text { Owyhee River } \\
\text { above } \\
\text { West Little } \\
\text { Owyhee River }\end{array}$ & $\begin{array}{c}\text { Owyhee } \\
\text { River } \\
\text { at } \\
\text { Three } \\
\text { Forks }\end{array}$ & $\begin{array}{l}\text { North } \\
\text { Fork } \\
\text { Owyhee } \\
\text { River }\end{array}$ & $\begin{array}{c}\text { Jordan } \\
\text { Creek }\end{array}$ & $\begin{array}{c}\text { Owyhee River } \\
\text { near } \\
\text { Rome }\end{array}$ & $\begin{array}{c}\text { Owyhee River } \\
\text { below } \\
\text { Crooked Creek }\end{array}$ & $\begin{array}{c}\text { Owyhee River } \\
\text { above } \\
\text { Bull Creek }\end{array}$ & $\begin{array}{c}\text { Owyhee } \\
\text { River } \\
\text { above } \\
\text { Lake } \\
\text { Owyhee }\end{array}$ \\
\hline USGS site ID ...... & 422015117024000 & 422650117121800 & 422650117121800 & 13177900 & 13177920 & 13180600 & 42501711737900 & 425442117432100 & 430631117425900 & 13182000 \\
\hline Site No... & OR7 & OR6 & $\mathrm{ORG}^{\mathrm{C}}$ & OR5 & NF1 & JC1 & OR4 & OR3 & OR2 & OR1 \\
\hline
\end{tabular}

Ephemeroptera

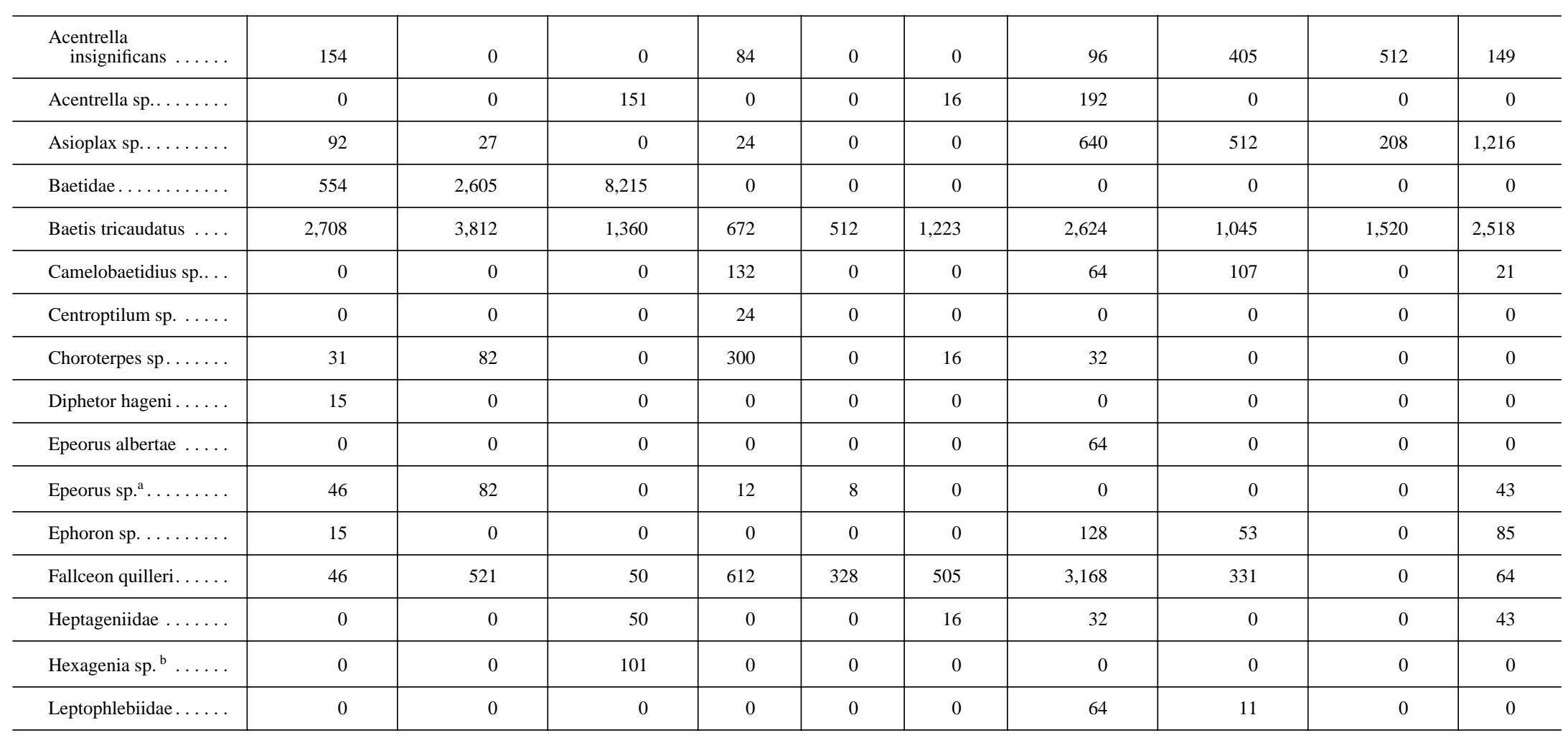




\begin{tabular}{|c|c|c|c|c|c|c|c|c|c|c|}
\hline Site name........ & $\begin{array}{c}\text { Owyhee River } \\
\text { at } \\
\text { State Line }\end{array}$ & $\begin{array}{l}\text { Owyhee River } \\
\text { above } \\
\text { West Little } \\
\text { Owyhee River }\end{array}$ & $\begin{array}{l}\text { Owyhee River } \\
\text { above } \\
\text { West Little } \\
\text { Owyhee River }\end{array}$ & $\begin{array}{l}\text { Owyhee } \\
\text { River } \\
\text { at } \\
\text { Three } \\
\text { Forks }\end{array}$ & $\begin{array}{c}\text { North } \\
\text { Fork } \\
\text { Owyhee } \\
\text { River }\end{array}$ & $\begin{array}{l}\text { Jordan } \\
\text { Creek }\end{array}$ & $\begin{array}{l}\text { Owyhee River } \\
\text { near } \\
\text { Rome }\end{array}$ & $\begin{array}{c}\text { Owyhee River } \\
\text { below } \\
\text { Crooked Creek }\end{array}$ & $\begin{array}{c}\text { Owyhee River } \\
\text { above } \\
\text { Bull Creek }\end{array}$ & $\begin{array}{c}\text { Owyhee } \\
\text { River } \\
\text { above } \\
\text { Lake } \\
\text { Owyhee }\end{array}$ \\
\hline USGS site ID ...... & 422015117024000 & 422650117121800 & 422650117121800 & 13177900 & 13177920 & 13180600 & 42501711737900 & 425442117432100 & 430631117425900 & 13182000 \\
\hline Site No.......... & OR7 & OR6 & ORG $^{c}$ & OR5 & NF1 & JC1 & OR4 & OR3 & OR2 & OR1 \\
\hline \multicolumn{11}{|l|}{ Ephemeroptera-Continued } \\
\hline Paracloeodes minutus. & 0 & 0 & 0 & 24 & 8 & 0 & 0 & 0 & 0 & 0 \\
\hline Paracloeodes sp ${ }^{\mathrm{b}} \ldots$. & 0 & 0 & 151 & 0 & 0 & 0 & 0 & 0 & 0 & 0 \\
\hline Plauditus sp......... & 1,231 & 1,892 & 706 & 48 & 0 & 0 & 0 & 11 & 0 & 0 \\
\hline $\begin{array}{l}\text { Stenonema } \\
\quad \text { terminatum ....... }\end{array}$ & 0 & 27 & 0 & 0 & 0 & 16 & 128 & 96 & 32 & 405 \\
\hline Tricorythodes sp...... & 215 & 247 & 706 & 228 & 16 & 82 & 192 & 672 & 208 & 1,259 \\
\hline \multicolumn{11}{|l|}{ Odonata } \\
\hline Argia emma......... & 15 & 0 & 0 & 0 & 0 & 0 & 0 & 0 & 0 & 0 \\
\hline Argia sp. .......... & 0 & 0 & 0 & 24 & 0 & 0 & 0 & 0 & 0 & 0 \\
\hline Coenagrionidae ...... & 0 & 0 & 0 & 0 & 0 & 0 & 32 & 0 & 0 & 0 \\
\hline $\begin{array}{l}\text { Erpetogomphus } \\
\quad \text { compositus ....... }\end{array}$ & 0 & 0 & 0 & 12 & 0 & 0 & 32 & 0 & 0 & 0 \\
\hline Erpetogomphus sp. ... & 0 & 0 & 0 & 0 & 0 & 0 & 0 & 0 & 0 & 21 \\
\hline Gomphidae ........ & 0 & 0 & 50 & 0 & 0 & 16 & 0 & 0 & 0 & 0 \\
\hline $\begin{array}{l}\text { Ophiogomphus occi- } \\
\text { dentis .............. }\end{array}$ & 92 & 27 & 0 & 12 & 0 & 0 & 128 & 64 & 0 & 43 \\
\hline Ophiogomphus sp..... & 0 & 0 & 10 & 24 & 0 & 0 & 0 & 0 & 0 & 0 \\
\hline \multicolumn{11}{|l|}{ Plecoptera } \\
\hline $\begin{array}{l}\text { Calineuria } \\
\quad \text { californica ........ }\end{array}$ & 0 & 0 & 0 & 0 & 40 & 0 & 0 & 0 & 0 & 0 \\
\hline Perlidae $^{\text {a }} \ldots \ldots \ldots$. & 0 & 0 & 0 & 0 & 0 & 0 & 0 & 0 & 0 & 21 \\
\hline Skwala sp. ......... & 0 & 0 & 0 & 0 & 16 & 0 & 0 & 0 & 0 & 0 \\
\hline
\end{tabular}


Table 9. Benthic invertebrate abundance in the Owyhee River and selected tributaries, Oregon, June through July, 2001—Continued

\begin{tabular}{|c|c|c|c|c|c|c|c|c|c|c|}
\hline Site name......... & $\begin{array}{c}\text { Owyhee River } \\
\text { at } \\
\text { State Line }\end{array}$ & $\begin{array}{c}\text { Owyhee River } \\
\text { above } \\
\text { West Little } \\
\text { Owyhee River }\end{array}$ & $\begin{array}{c}\text { Owyhee River } \\
\text { above } \\
\text { West Little } \\
\text { Owyhee River }\end{array}$ & $\begin{array}{c}\text { Owyhee } \\
\text { River } \\
\text { at } \\
\text { Three } \\
\text { Forks }\end{array}$ & $\begin{array}{l}\text { North } \\
\text { Fork } \\
\text { Owyhee } \\
\text { River }\end{array}$ & $\begin{array}{c}\text { Jordan } \\
\text { Creek }\end{array}$ & $\begin{array}{c}\text { Owyhee River } \\
\text { near } \\
\text { Rome }\end{array}$ & $\begin{array}{l}\text { Owyhee River } \\
\text { below } \\
\text { Crooked Creek }\end{array}$ & $\begin{array}{c}\text { Owyhee River } \\
\text { above } \\
\text { Bull Creek }\end{array}$ & $\begin{array}{c}\text { Owyhee } \\
\text { River } \\
\text { above } \\
\text { Lake } \\
\text { Owyhee }\end{array}$ \\
\hline USGS site ID ....... & 422015117024000 & 422650117121800 & 422650117121800 & 13177900 & 13177920 & 13180600 & 42501711737900 & 425442117432100 & 430631117425900 & 13182000 \\
\hline Site No.......... & OR7 & OR6 & OR6' & OR5 & NF1 & JC1 & OR4 & OR3 & OR2 & OR1 \\
\hline
\end{tabular}

Hemiptera

\begin{tabular}{|c|c|c|c|c|c|c|c|c|c|c|}
\hline Ambrysus sp......... & 15 & 0 & 50 & 84 & 8 & 261 & 32 & 21 & 0 & 0 \\
\hline \multicolumn{11}{|l|}{ Coleoptera } \\
\hline Dubiraphia sp........ & 15 & 0 & 101 & 0 & 0 & 0 & 0 & 0 & 0 & 0 \\
\hline Liodessus sp......... & 0 & 0 & 0 & 0 & 32 & 0 & 0 & 0 & 0 & 0 \\
\hline Microcylloepus sp. ... & 323 & 439 & 504 & 336 & 8 & 603 & 1,248 & 139 & 352 & 512 \\
\hline Optioservus sp. ...... & 0 & 55 & 50 & 0 & 88 & 0 & 0 & 0 & 0 & 0 \\
\hline Ordobrevia nubifera... & 0 & 0 & 0 & 0 & 16 & 0 & 0 & 0 & 0 & 0 \\
\hline Peltodytes sp......... & 0 & 0 & 0 & 0 & 0 & 16 & 0 & 0 & 0 & 0 \\
\hline Psephenus sp......... & 77 & 137 & 101 & 84 & 24 & 16 & 32 & 32 & 64 & 85 \\
\hline Stenelmis sp. ........ & 0 & 0 & 0 & 36 & 0 & 16 & 0 & 0 & 0 & 0 \\
\hline Zaitzevia sp.......... & 108 & 137 & 101 & 84 & 80 & 16 & 0 & 11 & 16 & 0 \\
\hline
\end{tabular}

Trichoptera

\begin{tabular}{|c|c|c|c|c|c|c|c|c|c|c|}
\hline $\begin{array}{l}\text { Brachycentrus occiden- } \\
\text { talis ............. }\end{array}$ & 0 & 0 & 0 & 0 & 0 & 0 & 0 & 0 & 496 & 128 \\
\hline Cheumatopsyche sp. .. & 0 & 0 & 0 & 216 & 8 & 49 & 3,200 & 885 & 736 & 1,152 \\
\hline Chimarra sp. . . . . . . & 108 & 55 & 101 & 12 & 0 & 0 & 448 & 96 & 256 & 192 \\
\hline Culoptila sp... . . . . . . & 0 & 0 & 0 & 0 & 0 & 0 & 0 & 0 & 16 & 0 \\
\hline Helicopsyche sp. ..... & 31 & 110 & 50 & 852 & 0 & 65 & 0 & 21 & 0 & 0 \\
\hline Hydropsyche sp. . .... & 46 & 82 & 0 & 156 & 112 & 408 & 1,536 & 213 & 1,152 & 1,664 \\
\hline Hydropsychidae...... . & 0 & 0 & 101 & 0 & 0 & 0 & 0 & 0 & 16 & 0 \\
\hline
\end{tabular}




\begin{tabular}{|c|c|c|c|c|c|c|c|c|c|c|}
\hline Site name........ & $\begin{array}{c}\text { Owyhee River } \\
\text { at } \\
\text { State Line }\end{array}$ & $\begin{array}{l}\text { Owyhee River } \\
\text { above } \\
\text { West Little } \\
\text { Owyhee River }\end{array}$ & $\begin{array}{l}\text { Owyhee River } \\
\text { above } \\
\text { West Little } \\
\text { Owyhee River }\end{array}$ & $\begin{array}{l}\text { Owyhee } \\
\text { River } \\
\text { at } \\
\text { Three } \\
\text { Forks }\end{array}$ & $\begin{array}{c}\text { North } \\
\text { Fork } \\
\text { Owyhee } \\
\text { River }\end{array}$ & $\begin{array}{l}\text { Jordan } \\
\text { Creek }\end{array}$ & $\begin{array}{c}\text { Owyhee River } \\
\text { near } \\
\text { Rome }\end{array}$ & $\begin{array}{c}\text { Owyhee River } \\
\text { below } \\
\text { Crooked Creek }\end{array}$ & $\begin{array}{c}\text { Owyhee River } \\
\text { above } \\
\text { Bull Creek }\end{array}$ & $\begin{array}{c}\text { Owyhee } \\
\text { River } \\
\text { above } \\
\text { Lake } \\
\text { Owyhee }\end{array}$ \\
\hline USGS site ID ....... & 422015117024000 & 422650117121800 & 422650117121800 & 13177900 & 13177920 & 13180600 & 42501711737900 & 425442117432100 & 430631117425900 & 13182000 \\
\hline Site No.......... & OR7 & OR6 & ORG $^{c}$ & OR5 & NF1 & JC1 & OR4 & OR3 & OR2 & OR1 \\
\hline \multicolumn{11}{|l|}{ Trichoptera-Continued } \\
\hline Hydroptila sp. ....... & 108 & 603 & 0 & 12 & 0 & 0 & 0 & 0 & 0 & 0 \\
\hline Hydroptilidae. ........ & 15 & 110 & 0 & 0 & 0 & 16 & 0 & 11 & 0 & 0 \\
\hline Leptoceridae ........ & 0 & 0 & 50 & 12 & 0 & 0 & 0 & 0 & 0 & 0 \\
\hline Leucotrichia sp....... & 0 & 0 & 0 & 0 & 0 & 0 & 0 & 43 & 400 & 0 \\
\hline Mayatrichia sp. ...... & 15 & 0 & 0 & 0 & 0 & 0 & 0 & 0 & 0 & 0 \\
\hline Neotrichia sp........ & 0 & 0 & 0 & 24 & 0 & 0 & 0 & 0 & 0 & 0 \\
\hline Ochrotrichia sp....... & 46 & 0 & 0 & 0 & 0 & 0 & 0 & 11 & 16 & 0 \\
\hline Oecetis avara ........ & 0 & 0 & 0 & 252 & 8 & 0 & 128 & 21 & 0 & 0 \\
\hline Oecetis sp.......... & 62 & 55 & 50 & 0 & 48 & 0 & 0 & 53 & 0 & 0 \\
\hline Onocosmoecus sp..... & 0 & 0 & 0 & 0 & 8 & 0 & 0 & 0 & 0 & 0 \\
\hline Protoptila sp. ........ & 0 & 55 & 0 & 12 & 8 & 0 & 256 & 107 & 48 & 213 \\
\hline \multicolumn{11}{|l|}{ Diptera } \\
\hline Antocha sp. ......... & 15 & 0 & 0 & 0 & 0 & 0 & 0 & 0 & 0 & 0 \\
\hline Atherix sp.......... & 15 & 27 & 0 & 36 & 0 & 0 & 0 & 32 & 32 & 64 \\
\hline $\begin{array}{l}\text { Bezzia/Palpomyia } \\
\text { sp. }^{\text {b } \ldots \ldots \ldots \ldots . . . ~}\end{array}$ & 0 & 0 & 202 & 0 & 0 & 0 & 0 & 0 & 0 & 0 \\
\hline Blepharicera sp....... & 0 & 0 & 0 & 0 & 8 & 0 & 0 & 0 & 0 & 0 \\
\hline Ceratopogonidae ..... & 0 & 0 & 0 & 0 & 0 & 16 & 0 & 0 & 0 & 0 \\
\hline Ceratopogoninae ..... & 123 & 165 & 0 & 12 & 24 & 33 & 0 & 32 & 16 & 0 \\
\hline Cryptolabis sp........ & 0 & 0 & 0 & 0 & 40 & 0 & 0 & 0 & 0 & 0 \\
\hline
\end{tabular}


Table 9. Benthic invertebrate abundance in the Owyhee River and selected tributaries, Oregon, June through July, 2001—Continued

\begin{tabular}{|c|c|c|c|c|c|c|c|c|c|c|}
\hline Site name........ & $\begin{array}{c}\text { Owyhee River } \\
\text { at } \\
\text { State Line }\end{array}$ & $\begin{array}{c}\text { Owyhee River } \\
\text { above } \\
\text { West Little } \\
\text { Owyhee River }\end{array}$ & $\begin{array}{c}\text { Owyhee River } \\
\text { above } \\
\text { West Little } \\
\text { Owyhee River }\end{array}$ & $\begin{array}{c}\text { Owyhee } \\
\text { River } \\
\text { at } \\
\text { Three } \\
\text { Forks }\end{array}$ & $\begin{array}{c}\text { North } \\
\text { Fork } \\
\text { Owyhee } \\
\text { River }\end{array}$ & $\begin{array}{c}\text { Jordan } \\
\text { Creek }\end{array}$ & $\begin{array}{c}\text { Owyhee River } \\
\text { near } \\
\text { Rome }\end{array}$ & $\begin{array}{c}\text { Owyhee River } \\
\text { below } \\
\text { Crooked Creek }\end{array}$ & $\begin{array}{c}\text { Owyhee River } \\
\text { above } \\
\text { Bull Creek }\end{array}$ & $\begin{array}{c}\text { Owyhee } \\
\text { River } \\
\text { above } \\
\text { Lake } \\
\text { Owyhee }\end{array}$ \\
\hline USGS site ID ...... & 422015117024000 & 422650117121800 & 422650117121800 & 13177900 & 13177920 & 13180600 & 42501711737900 & 425442117432100 & 430631117425900 & 13182000 \\
\hline Site No......... & OR7 & OR6 & $\mathbf{O R 6}^{\mathrm{c}}$ & OR5 & NF1 & JC1 & OR4 & OR3 & OR2 & OR1 \\
\hline
\end{tabular}

Diptera-Continued

\begin{tabular}{c|r|r|r|r|r|r|r|r|r|r}
\hline Hemerodromia sp.... & 0 & 0 & 0 & 0 & 0 & 0 & 0 & 0 \\
\hline Hexatoma sp........ & 15 & 0 & 2 & 0 & 16 & 0 & 0 & 0 \\
\hline Simulium sp........ & 185 & 1,179 & 555 & 60 & 664 & 196 & 288 & 0 \\
\hline Tipulidae ......... & 0 & 0 & 0 & 0 & 32 & 0 & 0 & 0 \\
\hline
\end{tabular}

\section{Chironomidae (family)}

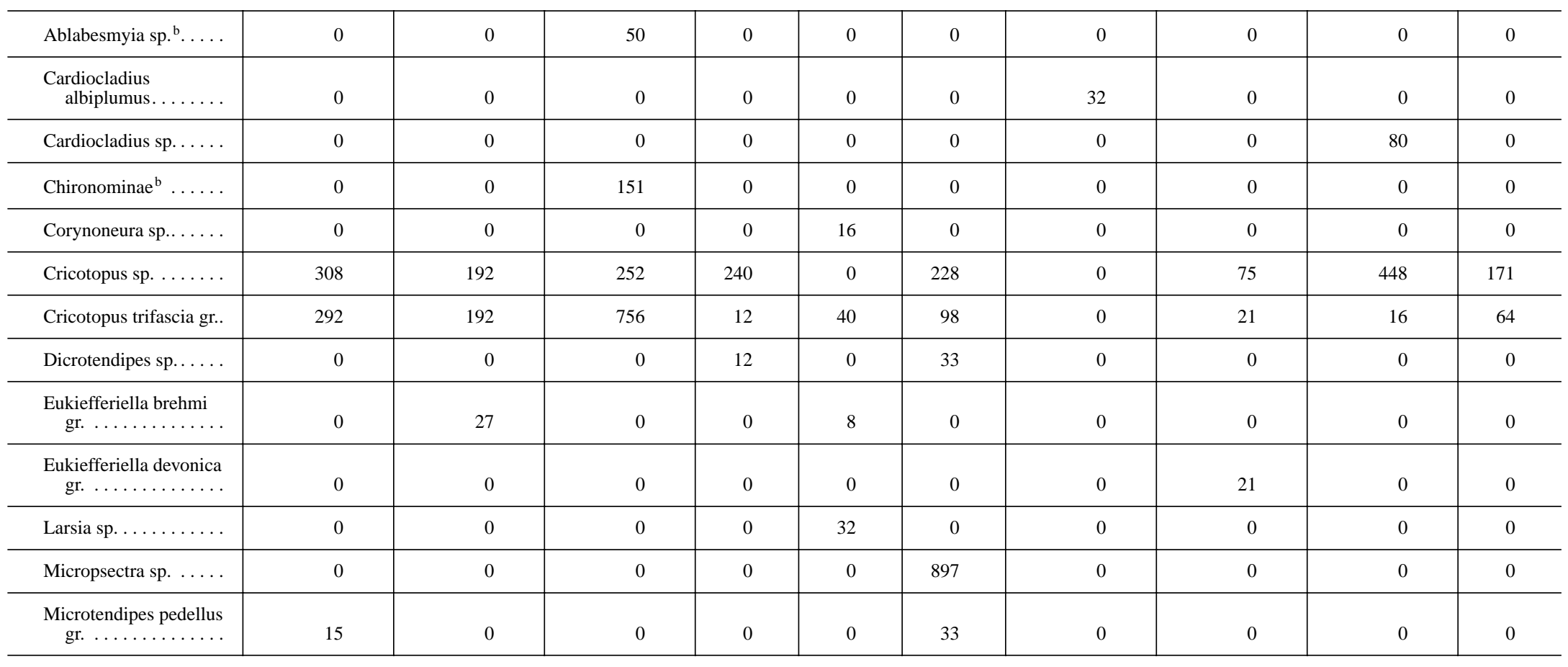




\begin{tabular}{|c|c|c|c|c|c|c|c|c|c|c|}
\hline Site name........ & $\begin{array}{c}\text { Owyhee River } \\
\text { at } \\
\text { State Line }\end{array}$ & $\begin{array}{c}\text { Owyhee River } \\
\text { above } \\
\text { West Little } \\
\text { Owyhee River }\end{array}$ & $\begin{array}{c}\text { Owyhee River } \\
\text { above } \\
\text { West Little } \\
\text { Owyhee River }\end{array}$ & $\begin{array}{c}\text { Owyhee } \\
\text { River } \\
\text { at } \\
\text { Three } \\
\text { Forks }\end{array}$ & $\begin{array}{c}\text { North } \\
\text { Fork } \\
\text { Owyhee } \\
\text { River }\end{array}$ & $\begin{array}{l}\text { Jordan } \\
\text { Creek }\end{array}$ & $\begin{array}{l}\text { Owyhee River } \\
\text { near } \\
\text { Rome }\end{array}$ & $\begin{array}{c}\text { Owyhee River } \\
\text { below } \\
\text { Crooked Creek }\end{array}$ & $\begin{array}{c}\text { Owyhee River } \\
\text { above } \\
\text { Bull Creek }\end{array}$ & $\begin{array}{c}\text { Owyhee } \\
\text { River } \\
\text { above } \\
\text { Lake } \\
\text { Owyhee }\end{array}$ \\
\hline USGS site ID ....... & 422015117024000 & 422650117121800 & 422650117121800 & 13177900 & 13177920 & 13180600 & 42501711737900 & 425442117432100 & 430631117425900 & 13182000 \\
\hline Site No.......... & OR7 & OR6 & ORG $^{\mathbf{c}}$ & OR5 & NF1 & JC1 & OR4 & OR3 & OR2 & OR1 \\
\hline \multicolumn{11}{|c|}{ Chironomidae (family)—Continued } \\
\hline Nanocladius sp. ${ }^{\mathrm{b}} . \ldots$. & 0 & 0 & 50 & 0 & 0 & 0 & 0 & 0 & 0 & 0 \\
\hline Orthocladiinae....... & 0 & 0 & 50 & 48 & 32 & 0 & 0 & 0 & 0 & 0 \\
\hline $\begin{array}{l}\text { Orthocladius } \\
\quad \text { Complex .......... }\end{array}$ & 15 & 0 & 0 & 24 & 0 & 33 & 64 & 0 & 512 & 448 \\
\hline Orthocladius sp....... & 15 & 55 & 0 & 144 & 160 & 33 & 32 & 64 & 0 & 0 \\
\hline Parametriocnemus sp. . & 15 & 27 & 0 & 0 & 0 & 0 & 0 & 0 & 0 & 0 \\
\hline Pentaneura sp. ${ }^{\mathrm{b}} \ldots \ldots$ & 0 & 0 & 101 & 0 & 0 & 0 & 0 & 0 & 0 & 0 \\
\hline Polypedilum sp....... & 123 & 82 & 302 & 36 & 440 & 130 & 480 & 64 & 16 & 341 \\
\hline $\begin{array}{l}\text { Pseudochironomus } \\
\quad \text { sp. . . . . . . . . . }\end{array}$ & 0 & 0 & 0 & 72 & 0 & 261 & 0 & 0 & 0 & 0 \\
\hline Rheocricotopus sp. ... & 15 & 165 & 0 & 0 & 56 & 65 & 64 & 43 & 16 & 0 \\
\hline Rheotanytarsus sp..... & 31 & 27 & 0 & 0 & 24 & 0 & 0 & 11 & 48 & 149 \\
\hline Robackia demeijerei . & 0 & 0 & 50 & 0 & 8 & 0 & 0 & 0 & 0 & 0 \\
\hline Stempellinella sp. .... & 154 & 603 & 302 & 0 & 8 & 0 & 0 & 0 & 0 & 0 \\
\hline Tanypodinae $^{\mathrm{b}} \ldots \ldots$ & 0 & 0 & 50 & 0 & 0 & 0 & 0 & 0 & 0 & 0 \\
\hline Tanytarsini. & 0 & 0 & 0 & 0 & 0 & 0 & 0 & 0 & 16 & 0 \\
\hline Tanytarsus sp. ....... & 46 & 0 & 0 & 180 & 64 & 0 & 64 & 32 & 0 & 0 \\
\hline Thienemanniella sp... . & 0 & 0 & 0 & 12 & 0 & 16 & 0 & 11 & 32 & 0 \\
\hline $\begin{array}{l}\text { Thienemannimyia } \\
\text { gr. sp.......... }\end{array}$ & 62 & 274 & 0 & 348 & 224 & 98 & 0 & 149 & 0 & 0 \\
\hline $\begin{array}{l}\text { Xenochironomus } \\
\text { xenolabis ..... }\end{array}$ & 0 & 0 & 0 & 0 & 0 & 0 & 0 & 11 & 0 & 0 \\
\hline
\end{tabular}


Table 9. Benthic invertebrate abundance in the Owyhee River and selected tributaries, Oregon, June through July, 2001—Continued

\begin{tabular}{|c|c|c|c|c|c|c|c|c|c|c|}
\hline Site name........ & $\begin{array}{c}\text { Owyhee River } \\
\text { at } \\
\text { State Line }\end{array}$ & $\begin{array}{c}\text { Owyhee River } \\
\text { above } \\
\text { West Little } \\
\text { Owyhee River }\end{array}$ & $\begin{array}{c}\text { Owyhee River } \\
\text { above } \\
\text { West Little } \\
\text { Owyhee River }\end{array}$ & $\begin{array}{c}\text { Owyhee } \\
\text { River } \\
\text { at } \\
\text { Three } \\
\text { Forks }\end{array}$ & $\begin{array}{c}\text { North } \\
\text { Fork } \\
\text { Owyhee } \\
\text { River }\end{array}$ & $\begin{array}{c}\text { Jordan } \\
\text { Creek }\end{array}$ & $\begin{array}{c}\text { Owyhee River } \\
\text { near } \\
\text { Rome }\end{array}$ & $\begin{array}{l}\text { Owyhee River } \\
\text { below } \\
\text { Crooked Creek }\end{array}$ & $\begin{array}{c}\text { Owyhee River } \\
\text { above } \\
\text { Bull Creek }\end{array}$ & $\begin{array}{c}\text { Owyhee } \\
\text { River } \\
\text { above } \\
\text { Lake } \\
\text { Owyhee }\end{array}$ \\
\hline USGS site ID ....... & 422015117024000 & 422650117121800 & 422650117121800 & 13177900 & 13177920 & 13180600 & 42501711737900 & 425442117432100 & 430631117425900 & 13182000 \\
\hline Site No......... & OR7 & OR6 & OR6 $^{\mathrm{C}}$ & OR5 & NF1 & JC1 & OR4 & OR3 & OR2 & OR1 \\
\hline \multicolumn{11}{|l|}{ Lepidoptera } \\
\hline Petrophila sp........ & 0 & 0 & 50 & 12 & 0 & 16 & 160 & 32 & 80 & 21 \\
\hline \multicolumn{11}{|l|}{ Arhynchobdellida } \\
\hline Erpobdellidae........ & 0 & 0 & 0 & 0 & 0 & 0 & 32 & 32 & 16 & 21 \\
\hline \multicolumn{11}{|l|}{ Rhynchobdellida } \\
\hline Helobdella stagnalis .. & 0 & 0 & 0 & 0 & 0 & 49 & 0 & 0 & 0 & 0 \\
\hline \multicolumn{11}{|l|}{ Oligochaeta (class) } \\
\hline Oligochaeta ......... & 123 & 110 & 302 & 72 & 0 & 1,859 & 128 & 139 & 160 & 107 \\
\hline \multicolumn{11}{|l|}{ Nematoda (phylum) } \\
\hline Nematoda........... & 154 & 110 & 353 & 12 & 48 & 65 & 480 & 43 & 64 & 0 \\
\hline Bivalvia & 0 & 0 & 0 & 0 & 0 & 0 & 0 & 11 & 0 & 0 \\
\hline Gonidea angulata..... & 169 & 0 & 0 & 0 & 0 & 0 & 0 & 0 & 0 & 0 \\
\hline \multicolumn{11}{|l|}{ Veneroida } \\
\hline Sphaeriidae ......... & 15 & 0 & 0 & 12 & 8 & 0 & 0 & 0 & 0 & 0 \\
\hline Sphaerium sp. ....... & 31 & 27 & 4 & 0 & 0 & 0 & 0 & 53 & 0 & 0 \\
\hline Gastropoda $^{\mathrm{b}}$ & 0 & 0 & 50 & 0 & 0 & 0 & 0 & 0 & 0 & 0 \\
\hline
\end{tabular}




\begin{tabular}{|c|c|c|c|c|c|c|c|c|c|c|}
\hline Site name........ & $\begin{array}{c}\text { Owyhee River } \\
\text { at } \\
\text { State Line }\end{array}$ & $\begin{array}{l}\text { Owyhee River } \\
\text { above } \\
\text { West Little } \\
\text { Owyhee River }\end{array}$ & $\begin{array}{l}\text { Owyhee River } \\
\text { above } \\
\text { West Little } \\
\text { Owyhee River }\end{array}$ & $\begin{array}{c}\text { Owyhee } \\
\text { River } \\
\text { at } \\
\text { Three } \\
\text { Forks }\end{array}$ & $\begin{array}{c}\text { North } \\
\text { Fork } \\
\text { Owyhee } \\
\text { River }\end{array}$ & $\begin{array}{l}\text { Jordan } \\
\text { Creek }\end{array}$ & $\begin{array}{c}\text { Owyhee River } \\
\text { near } \\
\text { Rome }\end{array}$ & $\begin{array}{c}\text { Owyhee River } \\
\text { below } \\
\text { Crooked Creek }\end{array}$ & $\begin{array}{c}\text { Owyhee River } \\
\text { above } \\
\text { Bull Creek }\end{array}$ & $\begin{array}{c}\text { Owyhee } \\
\text { River } \\
\text { above } \\
\text { Lake } \\
\text { Owyhee }\end{array}$ \\
\hline USGS site ID & 422015117024000 & 422650117121800 & 422650117121800 & 13177900 & 13177920 & 13180600 & 42501711737900 & 425442117432100 & 430631117425900 & 13182000 \\
\hline Site No......... & OR7 & OR6 & OR6 ${ }^{c}$ & OR5 & NF1 & JC1 & OR4 & OR3 & OR2 & OR1 \\
\hline
\end{tabular}

Basommatophora

\begin{tabular}{|c|c|c|c|c|c|c|c|c|c|c|}
\hline Ferrissia sp. ........ & 0 & 0 & 0 & 0 & 0 & 196 & 0 & 0 & 0 & 0 \\
\hline Fossaria sp. ........ & 0 & 0 & 0 & 0 & 0 & 49 & 0 & 0 & 0 & 0 \\
\hline Gyraulus sp.......... & 0 & 0 & 0 & 24 & 0 & 0 & 0 & 0 & 0 & 0 \\
\hline Lymnaeidae ......... & 0 & 0 & 0 & 0 & 0 & 16 & 0 & 0 & 0 & 0 \\
\hline Physella sp. ........ & 0 & 0 & 0 & 0 & 0 & 16 & 0 & 0 & 0 & 0 \\
\hline Physidae............ & 0 & 0 & 0 & 60 & 0 & 0 & 0 & 0 & 0 & 0 \\
\hline Planorbidae ........ & 0 & 0 & 0 & 0 & 0 & 49 & 0 & 0 & 0 & 0 \\
\hline Radix auricularia ..... & 0 & 0 & 0 & 0 & 0 & 16 & 0 & 0 & 0 & 0 \\
\hline Vorticifex effusa. ..... & 15 & 0 & 0 & 48 & 0 & 0 & 0 & 0 & 0 & 0 \\
\hline
\end{tabular}

\section{Neotaenioglossa}

\begin{tabular}{c|c|c|c|c|c|c|c|c|c|c|c}
\hline Fluminicola sp. ..... & 31 & 0 & 50 & 0 & 0 & 0 & 0 & 0 \\
\hline $\begin{array}{c}\text { Potamopyrgus antipo- } \\
\text { darum } \ldots \ldots \ldots \ldots\end{array}$ & 0 & 0 & 0 & 0 & 0 & 0 & 0 & 0 \\
\hline Valvata sp. ${ }^{\mathrm{b}} \ldots \ldots \ldots$ & 0 & 0 & 50 & 0 & 0 & 0 & 0 & 0 \\
\hline
\end{tabular}

\section{Amphipoda}

\begin{tabular}{|c|c|c|c|c|c|c|c|c|c|c|}
\hline Hyalella sp. . . . . . . . & 0 & 55 & 0 & 132 & 0 & 0 & 0 & 0 & 0 & 43 \\
\hline \multicolumn{11}{|l|}{ Ostracoda } \\
\hline Ostracoda............ & 0 & 55 & 0 & 36 & 0 & 16 & 64 & 11 & 0 & 0 \\
\hline
\end{tabular}


Table 9. Benthic invertebrate abundance in the Owyhee River and selected tributaries, Oregon, June through July, 2001—Continued

\begin{tabular}{|c|c|c|c|c|c|c|c|c|c|c|}
\hline Site name...... & $\begin{array}{c}\text { Owyhee River } \\
\text { at } \\
\text { State Line }\end{array}$ & $\begin{array}{c}\text { Owyhee River } \\
\text { above } \\
\text { West Little } \\
\text { Owyhee River }\end{array}$ & $\begin{array}{c}\text { Owyhee River } \\
\text { above } \\
\text { West Little } \\
\text { Owyhee River }\end{array}$ & $\begin{array}{c}\text { Owyhee } \\
\text { River } \\
\text { at } \\
\text { Three } \\
\text { Forks }\end{array}$ & $\begin{array}{c}\text { North } \\
\text { Fork } \\
\text { Owyhee } \\
\text { River }\end{array}$ & $\begin{array}{l}\text { Jordan } \\
\text { Creek }\end{array}$ & $\begin{array}{l}\text { Owyhee River } \\
\text { near } \\
\text { Rome }\end{array}$ & $\begin{array}{c}\text { Owyhee River } \\
\text { below } \\
\text { Crooked Creek }\end{array}$ & $\begin{array}{c}\text { Owyhee River } \\
\text { above } \\
\text { Bull Creek }\end{array}$ & $\begin{array}{c}\text { Owyhee } \\
\text { River } \\
\text { above } \\
\text { Lake } \\
\text { Owyhee }\end{array}$ \\
\hline USGS site ID ....... & 422015117024000 & 422650117121800 & 422650117121800 & 13177900 & 13177920 & 13180600 & 42501711737900 & 425442117432100 & 430631117425900 & 13182000 \\
\hline Site No... & OR7 & OR6 & $\mathrm{ORG}^{\mathrm{C}}$ & OR5 & NF1 & JC1 & OR4 & OR3 & OR2 & OR1 \\
\hline
\end{tabular}

Turbellaria (class)

\begin{tabular}{|c|c|c|c|c|c|c|c|c|c|c|}
\hline Turbellaria .......... & 62 & 27 & 101 & 324 & 32 & 179 & 320 & 128 & 112 & 107 \\
\hline \multicolumn{11}{|l|}{ Hydroida } \\
\hline Hydra sp. ............ & 0 & 0 & 0 & 0 & 0 & 49 & 0 & 0 & 0 & 0 \\
\hline
\end{tabular}

Acari (=Acarina)

\begin{tabular}{c|c|c|c|c|c|c|c|c|c|c|c}
\hline Acari $\ldots \ldots \ldots \ldots$ & 215 & 274 & 706 & 24 & 256 & 33 & 160 & 256 \\
\hline Chrysomelidae...... & 15 & 0 & 0 & 0 & 0 & 0 & 0 & 0 \\
\hline Total abundance (no./m) & 8,457 & 14,833 & 17,449 & 6,396 & 3,616 & 8,134 & 16,864 & 6,039 & 8,144 & 11,733 \\
\hline
\end{tabular}

${ }^{a}$ Coldwater taxon according to Idaho Division of Environmental Quality (Grafe and others, 2002).

${ }^{\mathrm{b}}$ Identified only in duplicate sample analyzed by the USGS lab, Denver.

${ }^{c}$ Quality assurance duplicate - 1/2 split. 
